\title{
METABOLISM OF SELENITE, SELENOMETHIONINE AND FEED-INCORPORATED SELENIUM IN LACTATING GOATS AND DAIRY COWS
}

Selostus: Seleeniaineenvaihdunta maitoa tuottavalla vuohella ja lehmällä

\section{PENTTI ASPILA}

Department of Animal Husbandry,

University of Helsinki

SF-00710 Helsinki, Finland

\section{ACADEMIC Dissertation}

TO BE PRESENTED, WITH THE PERMISSION OF THE FACUlty OF Agriculture AND Forestry OF THE UNIVERSITY OF HELSINKI, FOR PUBLIC CRITICISM in Auditorium XiI, Unioninkatu 34 Helsinki, ON MAY 11th 1991, AT 10 O'CLOCK.

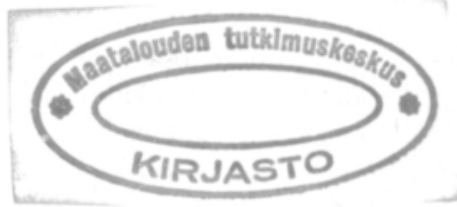





\section{ACKNOWLEDGEMENTS}

The present study was carried out in the Department of Animal Husbandry, University of Helsinki in collaboration with the Department of Food Chemistry and Technology and the Instrument Center of the Faculty of Agriculture and Forestry, University of Helsinki.

I want to express my sincere gratitude to prof. Liisa Syrjälä-Qvist, who proposed the subject for my dissertation and has supported it in all stages.

I also want to express my warm gratitude to prof. Esko Poutiainen for his encouragement to continue my studies after graduation.

My special gratitude I express to Antti Uusi-Rauva for his cooperation and advice in conducting experiments with radioisotopes.

I am very grateful to Dr. Marja Mutanen and Dr. Ruth Blauwiekel, the referees of this work, who have given invaluable advice and criticism in finalizing this thesis.

My sincere thanks as well to my colleagues especially to Mikko Tuori, associate prof. Matti Näsi and Dr. Pekka Huhtanen for discussions and interest during the work.

I also want express my gratitude to prof. Pekka Koivistoinen for his interest and support in the study.

I am indebted to Jari Lehto and Jukka Loimaranta for carrying out selenium analysis, to Dr. Satu Sankari for blood analysis and to Dr. Vieno Piironen for tocopherol analysis.

I am indebted to Raija Toropainen, Jukka Niemi and Timo Laitinen for their technical assistance in carrying out the experiments.

I also want to express my best thanks to Seppo Karttunen, Jorma Tossavainen and technical staff in Suitia experimental farm for their cooperation in carrying out the experiment on cows.

This study was initially supported by Foundation for Promotion of Food Production. Funds were also awarded by Ministry of Agriculture and Forestry, The Tiura Foundation, The Finnish Cultural Foundation, Finnish Academy, University of Helsinki, Kemira ltd. and Valio ltd. 



\section{Metabolism of selenite, selenomethionine and feed-incorporated selenium in lactating goats and dairy cows}

\section{Contents}

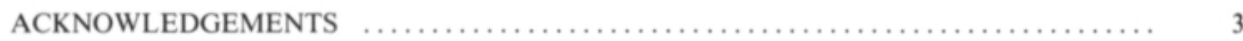

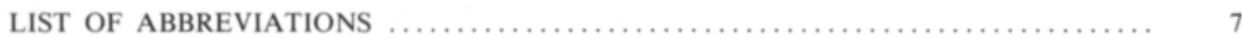

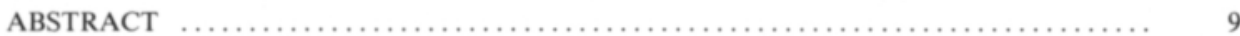

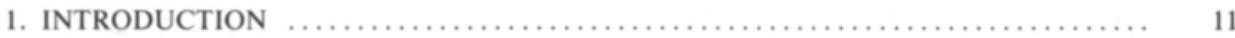

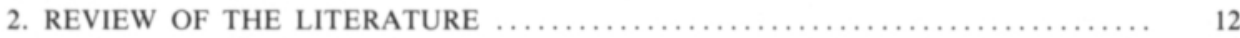

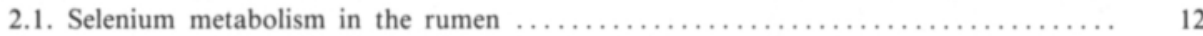

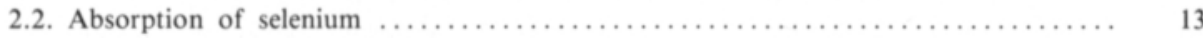

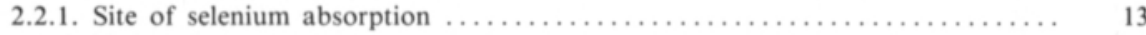

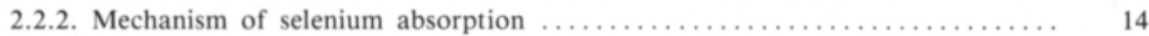

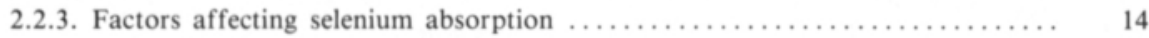

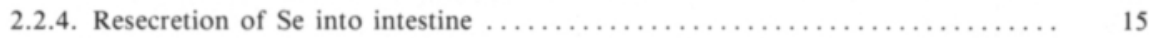

2.3. Metabolism and chemical forms of selenium in tissues $\ldots \ldots \ldots \ldots \ldots \ldots \ldots .15$

2.3.1. Selenium in erythrocytes and plasma $\ldots \ldots \ldots \ldots \ldots \ldots \ldots \ldots \ldots \ldots \ldots \ldots$

2.3.2. Selenium metabolism in the liver $\ldots \ldots \ldots \ldots \ldots \ldots \ldots \ldots \ldots \ldots \ldots \ldots \ldots$

2.3.2.1. Enzymatic synthesis of selenocysteine in liver ............... 18

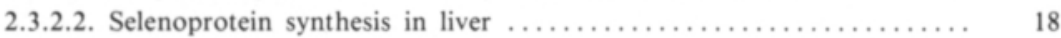

2.3.2.3. Synthesis of methylated selenocompounds .................. 19

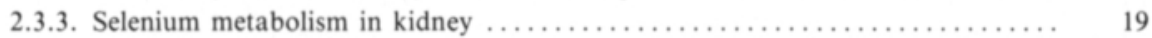

2.3.4. Selenium metabolism in the mammary gland $\ldots \ldots \ldots \ldots \ldots \ldots \ldots \ldots \ldots \ldots$

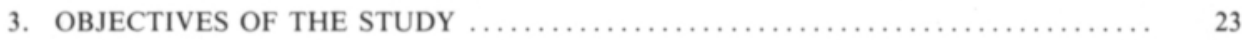

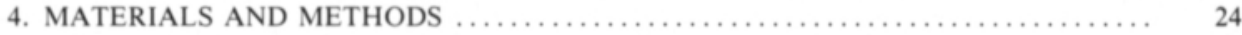

4.1. Experiment 1 (goats fed Se depleted and supplemented diets) . . . . . . . . . . . 24

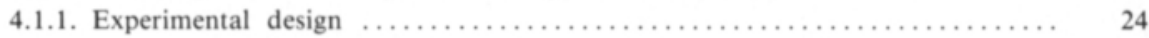

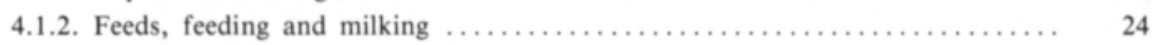

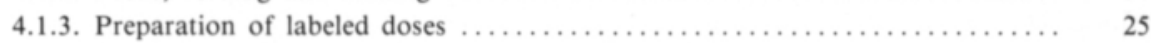

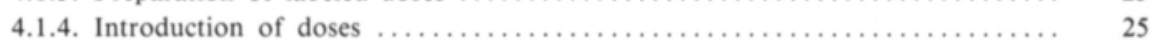

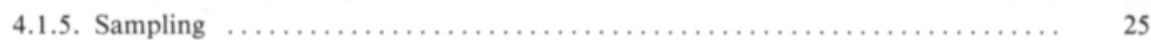

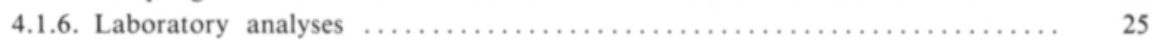

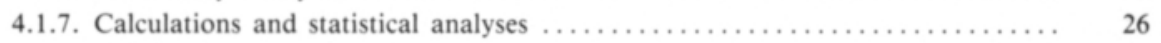

4.2. Experiment 2 (goats fed diets supplemented with sodium selenite or selenited barley) 27

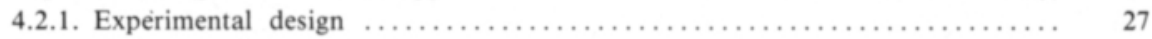

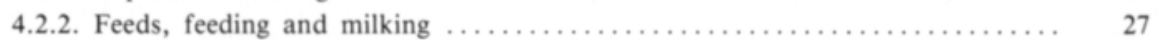

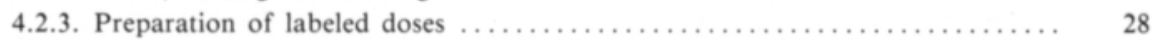

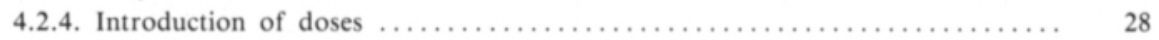

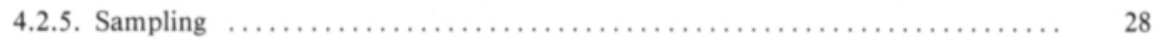

4.2.6. Laboratory analyses, calculations and statistical analyses $\ldots \ldots \ldots \ldots \ldots \ldots .28$ 
4.3. Experiment 3 (dairy cows fed diets supplemented with sodium selenite or selenited silage) 29

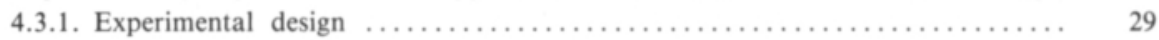

4.3.2. Preparation of selenited feeds . . . . . . . . . . . . . . . . . . . . .

4.3.3. Feeding, dietary composition and production $\ldots \ldots \ldots \ldots \ldots \ldots \ldots \ldots \ldots \ldots$

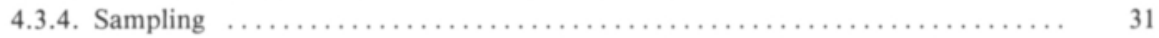

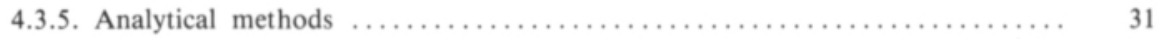

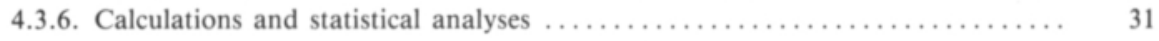

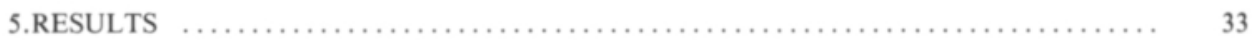

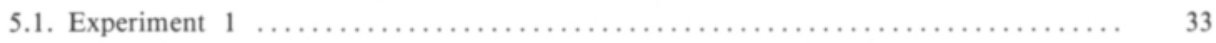

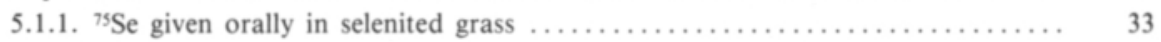

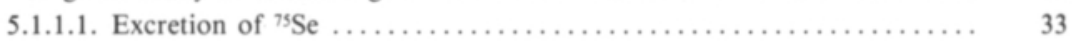

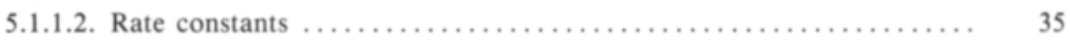

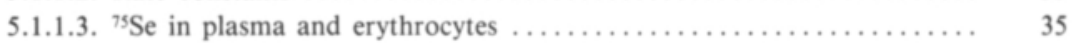

5.1.2. ${ }^{75}$ Se given intraruminally as sodium selenite $\ldots \ldots \ldots \ldots \ldots \ldots \ldots \ldots \ldots \ldots \ldots$

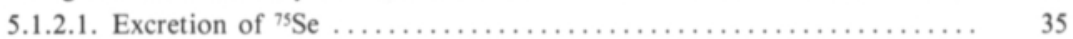

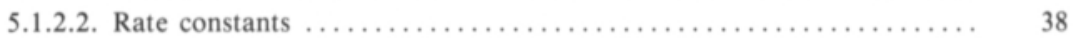

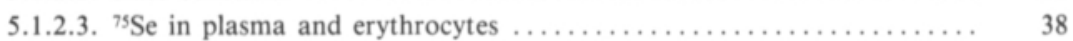

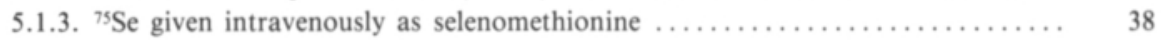

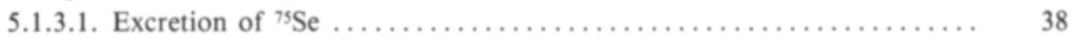

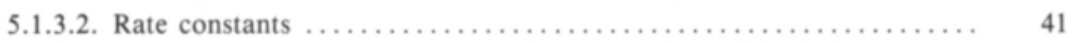

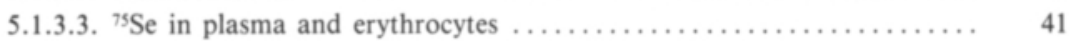

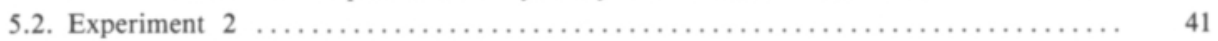

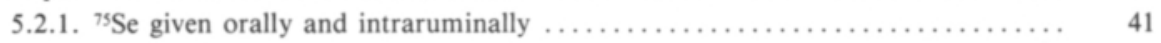

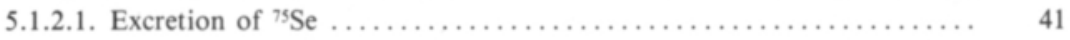

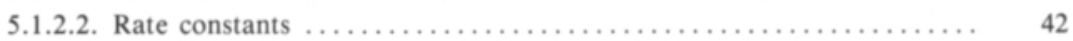

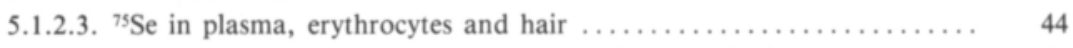

5.2.2. ${ }^{75} \mathrm{Se}$ given intravenously as sodium selenite and selenomethionine $\ldots \ldots \ldots \ldots \quad 44$

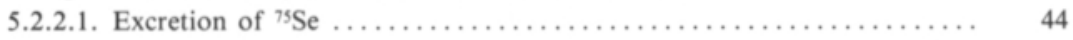

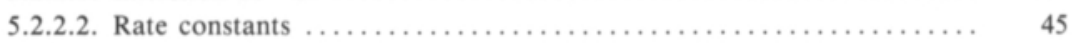

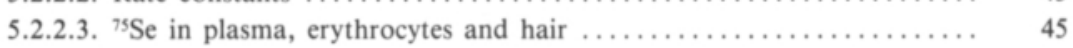

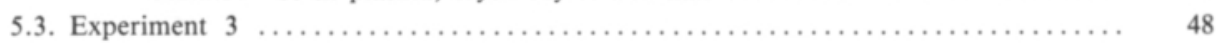

5.3.1. Blood parameters $\ldots \ldots \ldots \ldots \ldots \ldots \ldots \ldots \ldots \ldots \ldots \ldots \ldots \ldots \ldots \ldots \ldots \ldots, 48$

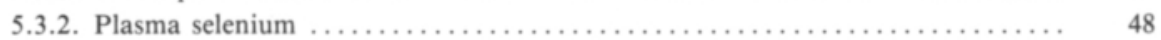

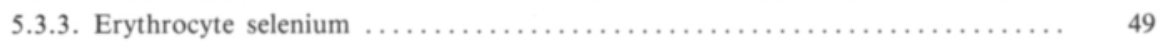

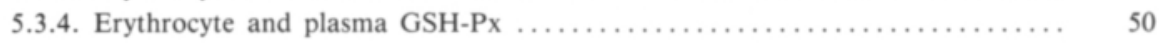

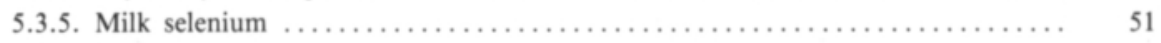

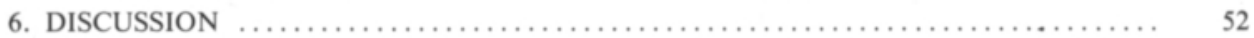

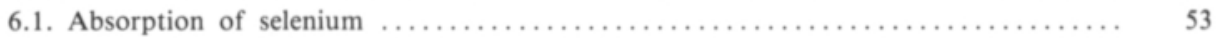

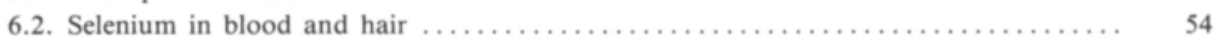

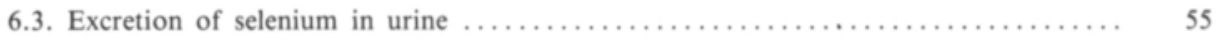

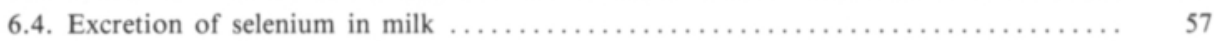

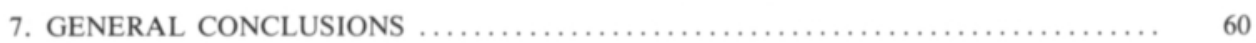

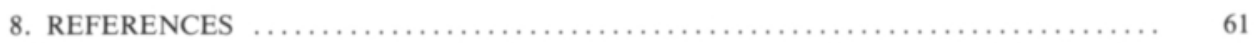

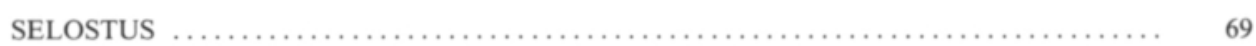

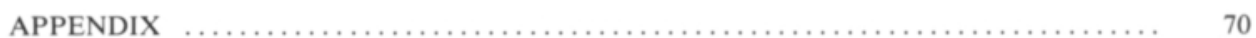




\section{List of abbreviations}

\begin{tabular}{|c|c|}
\hline AP & alkaline phosphatase \\
\hline ASAT & aspartate amino transferase \\
\hline $\mathrm{Bq}$ & Bequerelle, disintegration per second \\
\hline CK & creatine kinase \\
\hline cpm & counts per minute \\
\hline DM & dry matter \\
\hline FSe & $\begin{array}{l}\text { selenium in other than mineral feeds } \\
\text { (energy and protein feeds) }\end{array}$ \\
\hline$\gamma-\mathrm{GT}$ & $\gamma$-glutamyl transferase \\
\hline GSH & reduced glutathione \\
\hline GSH-Px & glutathione peroxidase \\
\hline GSSeSG & selenodiglutathione \\
\hline k & rate constant \\
\hline kat & katal, mmol of substrate oxidized per second \\
\hline I.R. & intraruminal \\
\hline I.V. & intravenous \\
\hline IO & inorganic selenium \\
\hline OR & organic selenium \\
\hline MSe & selenium in mineral feeds \\
\hline TMRT & total mean retention time \\
\hline TMSe & trimethylselenonium ion \\
\hline TT & transit time \\
\hline $\mathbf{T}_{1 / 2}$ & half-life \\
\hline
\end{tabular}





\title{
Metabolism of selenite, selenomethionine and feed-incorporated selenium in lactating goats and dairy cows
}

\author{
PENTTI ASPILA \\ Department of Animal Husbandry, University of Helsinki \\ SF-00710 Helsinki, Finland
}

\begin{abstract}
The objective of this study was to investigate the metabolism of inorganic and organic Se sources at different dietary Se levels in lactating goats and dairy cows.

The study consists of two experiments on goats dosed singly, either orally with grass sprayed with $\mathrm{Na}_{2}{ }^{75} \mathrm{SeO}_{3}$ one week before cutting, intraruminally (I.R.) with $\mathrm{Na}_{2}{ }^{75} \mathrm{SeO}_{3}$, or intravenously (I.V.) with $\mathrm{Na}_{2}{ }^{75} \mathrm{SeO}_{3}$ or ${ }^{75} \mathrm{Se}$-selenomethionine. Follow-up periods were from 15 to $28 \mathrm{~d}$ long. Dietary Se levels were $0.05,0.22$ and $0.34 \mathrm{mg} / \mathrm{kg} \mathrm{DM}$. Values for ${ }^{75} \mathrm{Se}$ absorption, excretion in milk, urine and faeces, ${ }^{75} \mathrm{Se}$ activity in plasma, erythrocytes and hair are presented. In another experiment lasting $539 \mathrm{~d}, 48$ dairy cows were fed either $\mathrm{Na}_{2} \mathrm{SeO}_{3}$ or grass silage sprayed with $\mathrm{Na}_{2} \mathrm{SeO}_{3}$ one week before cutting. Dietary Se levels were from 0.03 to $1.8 \mathrm{mg} / \mathrm{kg} \mathrm{DM}$. Se content in milk, plasma and erythrocytes, and GSH-Px activity in erythrocytes and plasma are given.

True absorption of ${ }^{75} \mathrm{Se}$ was $63 \%$ and $65 \%$, and excretion of ${ }^{75} \mathrm{Se}$ in milk $4 \%$ and 7 $\%$ in the goats dosed I.R. with $\mathrm{Na}_{2}{ }^{75} \mathrm{SeO}_{3}$ and orally with ${ }^{75} \mathrm{Se}$-labeled grass. The effect of dietary Se content was non-significant. After I.V. dose, $3.6 \%$ and $33 \%$ of ${ }^{75}$ Se was excreted in milk in goats dosed with $\mathrm{Na}_{2}{ }^{75} \mathrm{SeO}_{3}$ and ${ }^{75} \mathrm{Se}$-selenomethionine, respectively, $\mathrm{Na}_{2}{ }^{75} \mathrm{SeO}_{3}$ being eliminated mainly via urine.

In cows receiving selenium as $\mathrm{Na}_{2} \mathrm{SeO}_{3}$, milk contained $0.011,0.011,0.016$ and $0.020 \mathrm{mg}$ $\mathrm{Se} / \mathrm{l}$ at dietary Se levels $0.11,0.17,0.42$ and $0.68 \mathrm{mg} / \mathrm{kg} \mathrm{DM}$, respectively. In cows receiving Se-sprayed silage, milk Se content was $0.023,0.020,0.029$ and $0.040 \mathrm{mg} / 1$ when the diet contained $0.09,0.20,0.45$ and $1.20 \mathrm{mg} \mathrm{Se} / \mathrm{kg} \mathrm{DM}$. Se incorporated into silage was more efficient $(\mathrm{p}<0.001)$ in raising milk Se content than selenite. When the animals were fed Se depleted diets, milk Se content of the cows supplemented with selenite decreased more rapidly $(\mathrm{p}<0.001)$ than that of the cows supplemented with selenited silage.
\end{abstract}

Index words: Selenium, feed selenium, selenite, selenomethionine, metabolism, glutathione peroxidase, milk, blood, hair, dairy cow, goat 



\section{INTRODUCTION}

The selenium content of feed and food grown in Finland has been well below the accepted dietary requirements (SIPPOLA 1979, VARO \& KoIvistoInen 1981). There has also been evidence linking dietary selenium content to some diseases (e.g. cardiovascular diseases, SALONEn et al. 1982). These assumptions led in the early 1980 's to the need to investigate possibilities to increase dietary selenium intake in the Finnish population.

Even though since 1969 commercial mineral mixtures had been fortified with inorganic selenium this had not had any distinct impact on selenium content in milk or meat. There was also evidence from previous studies that organic forms of selenium would be transferred into milk and retained in tissues more efficiently than inorganic Se (e.g. JACOBSEN et al. 1965, Conrad and Moxon 1979, Maus et al. 1980). Thus fortifying selenium in fertilizers was anticipated to be the best means of supplying the Finnish population and also domestic animals with adequate selenium. Investigations of plant uptake of various seleno compounds were succesfully carried out by Dr. Toivo Yläranta. Based on his results, it was concluded that sodium selenate would be the most suitable form of selenium to be added to fertilizers given prevailing conditions in Finland (Yläranta 1984a).
This research programme was established to investigate appropriate feed selenium content for achieving suitable selenium content in milk and meat products. Prof. Liisa SyrjäläQvist was the chairman of the group and Mr. Pentti Aspila was requested to work as researcher. The programme was implemented in 1982 and its objective was to develop recommendations for raising the selenium content in cow milk and in beef to an appropriate level. The chemical form of Se employed in this study was sodium selenite, a reduced product of sodium selenate, because it is the best documented seleno compound and in foliar applications it has been similar to sodium selenate (YLÄRANTA 1984b). In this doctoral thesis the results from two experiments on lactating goats and the results from one experiment on lactating dairy cows are presented.

Since 1984 Finnish fertilizers have been supplemented with sodium selenate, which has increased the selenium content of feeds from the level of $0.02 \mathrm{mg} / \mathrm{kg}$ DM to the level of 0.2 $\mathrm{mg} / \mathrm{kg} \mathrm{DM}$. As a result the Se content of animal products has also increased and at the present, the intake of Se from the average Finnish diet meets standard recommendations. Meat products contribute $40 \%$ and milk products $20 \%$ of the total selenium intake (Екноцм et al. 1991). 


\section{REVIEW OF THE LITERATURE}

\subsection{Selenium metabolism in the rumen}

Investigations on the chemical nature of seleno-compounds of plant origin have demonstrated the presence of several seleno compounds, e.g. selenomethionine, selenocysteine, selenite, selenocysteic acid, selenocystathione, Se-methylselenomethionine, Semethylselenocysteine and others. (Peterson and Butler 1962, Jenkins and Hidiroglou 1967, Shrift 1969, Olson et al. 1970, Nigam and McConnell 1976, Burk 1976, UlRey 1981, Gissel-Nielsen 1987). Of these the main selenium compounds ingested by ruminants are isologs of methionine and cystine. In soya proteins selenium is probably in the form of selenocysteine (MASON and WEAVER 1988). About $70 \%$ of selenium is proteinbound in lucerne (Peterson and Spedding 1963, JoNES and GoDwIN 1963) and about $60 \%$ in brome grass (JENKINS and HidiRoGLOU 1967). GisSEL-NIELSEN (1976) suggested that normally $80 \%$ of selenite-Se given to plants is incorporated into either protein or free amino acids. Fortifying sulphur and nitrogen might have some influence on the distribution and chemical form of selenium in plants (GISSEL-NIELSEN 1982).

In the rumen, plant proteins undergo extensive bacterial proteolysis resulting in the liberation of a considerable proportion of the amino acids and reutilization for microbial protein synthesis. Compared to sulphur, selenium has been shown to be incorporated in vitro more rapidly into bacterial protein; the incorporation of selenite is faster than that for selenate or selenomethionine (PAULSON et al.
1968). A small amount of inorganic selenium could also be incorporated into seleno-amino acids by rumen microbes. The compounds identified are mainly selenomethionine, selenomethionine selenoxide, selenocysteine and compounds resembling taurine and homocysteine (Hidiroglou et al. 1968, Hudman and GLENN 1984). Selenite and selenate, however, were not incorporated into selenomethionine even though under the same conditions sulphate-sulphur was utilized in methionine synthesis with subsequent incorporation into microbial proteins (PAULSON et al. 1968). At low sulphur intake (PoPE et al. 1979) or at high selenium intake (ROSENFELD 1962) incorporation of inorganic selenium into microbial protein tends to increase. Incorporation of selenite is inhibited by sulphite and nitrite (Hudman and Glenn 1984).

Some selenomethionine can be metabolized by the rumen bacteria to form selenocysteine in a such way that both compounds are incorporated into bacterial protein (WHANGER et al. 1967, Hidiroglou et al. 1974). This conversion, however, has not been found in all studies (PAulson et al. 1968). The reason for this might be the instability of selenocysteine (Butler and Peterson 1967). Incorporation of seleno-amino acids into rumen bacteria is a rapid process resulting in about half of the dosed selenomethionine being associated with rumen bacteria within the first $6 \mathrm{hrs}$. Thereafter the proportion of selenium associated with rumen bacteria is slowly decreased with a coinciding increase in proportion of ingesta + protozoa associated Se. It is assumed that only a minor proportion of this selenium is bound to the protozoa. The proportion of protein-bound selenium is found to be about 
$80 \%$ in ingesta + protozoal fraction, but only about $65 \%$ in bacterial protein (Hidiroglou et al. 1974). The average turnover rate for protein-bound selenium has been only $70 \%$ of that observed for sulphur (Hidiroglou et al. 1968).

Supplementing selenium to sheep has been shown to increase the number of rumen bacteria and also to have some effect on rumen bacterial composition (Hidiroglou et al. 1968). This might result in improved microbial protein synthesis. The effect of sulphur on selenium metabolism may arise from the fact that increasing sulphur in the diet has increased the population of Desulphovibrio bacteria in the rumen (SHRIFT 1973) and thus more selenium is enzymatically reduced to $\mathrm{H}_{2} \mathrm{Se}$ (Pope et al. 1979). $\mathrm{H}_{2} \mathrm{Se}$ is an unstable compound, which might be reduced further to elemental selenium or to highly insoluble metal selenides (Hidiroglou and Jenkins 1973). Some of $\mathrm{H}_{2} \mathrm{Se}$ can also be eliminated from the rumen via eructation (LOPEz et al. 1968). HandereK and Godwin (1970) found one percent of dosed selenium in expired air. However, PAulson et al. (1968) could not find any volatile selenium even under the same conditions in which some volatile sulphur was formed. High selenium intake (LoPEz et al. 1968) and also in some cases high dietary protein level (GANTHER et al. 1966) may increase expired selenium.

Part of the selenium given to animals in organic form or as sodium selenite or selenate is metabolized to elemental selenium, which is utilized to some extent by rumen microbes (Handerek and Godwin 1970, Hudman and GLENN 1984), or further to highly insoluble selenides which can be utilized neither by microbes nor by the host (PoPE et al. 1979).

\subsection{Absorption of selenium}

\subsubsection{Site of Se absorption}

There is no net absorption of selenite from the rumen (WRIGHT and BELL 1966) although a small amount of selenomethionine may be absorbed (Hidiroglou and Jenkins 1973). Absorption of selenomethionine from the rumen is a rapid process, but accounts for only about $2 \%$ of the total absorption of selenomethionine. The absorption is similar to that of methionine (VENKov 1969). Cysteine is absorbed from the rumen to a much lesser extent than methionine (LAZAROv and Ivanov 1970), but there are no studies of the ruminal absorption of selenocysteine. Some selenium is, however, recycled back into the rumen, mostly via saliva (DEJNEKA et al. 1979), resulting in almost zero net absorption from the rumen (Hidiroglou and Jenkins 1974).

In the omasum some selenomethionine is absorbed, but some work suggests that more selenium is secreted back to the omasum leading to the zero or even negative net absorption of selenium from the omasum (Hidiroglou and Jenkins 1973). However, LANGLANDS et al. (1986) found a slight tendency for decreased outflow of Se from the omasum when compared to outflow from the rumen.

Selenite may be absorbed in the abomasum to some extent in sheep (WRIGHT and BeLL 1966), but not in the rat (Whanger et al. 1976) or in swine (WRIGHT and BELL 1966). In contrast to selenite, some selenomethionine is absorbed in mice (HANSON and JACOBSEN 1966), rats (WHANGER et al. 1976) and sheep (LANGLANDS et al. 1986). Absorption is greater from the pyloric and fundic portions of the abomasum than from the mucosal epithelial segment (HANSON and JACOBSEN 1966).

The main site for selenium absorption varies from species to species, but is always located in a small intestine. In rats (WhANGer et al. 1976) and in chicks (Pesti and Combs 1976, Humaloja and MyKKänen 1986) selenite and selenomethionine are absorbed from the duodenum more efficiently than from the jejunum or ileum, but in sheep absorption is most efficient the from midjejunum (HidiROGLOU and JENKINS 1974). Selenate-Se is absorbed in rats most efficiently from the ileum followed in descending order by the proximal 
jejunum and large intestine (caecum and colon) (Wolframm et al. 1985). In swine and sheep net absorption is greatest in the distal 4/5 of the small intestine (WRIGHT and BELL 1966), probably due to extensive secretion of Se into the duodenum.

\subsubsection{Mechanism of Se absorption}

Most investigations on the absorption mechanism of Se are carried out with laboratory animals and results in ruminants are limited. Ruminant nutritionists therefor are compelled to extrapolate from data obtained from laboratory animals. Selenomethionine is transferred actively across the intestinal wall in the golden hamster (McConNELL and $\mathrm{CHO}$ 1967), the chick (HumaloJa and MYKKÄNEN 1986) and the rat (Thomson and Sterwart 1973). Transport is dependent upon the ATPdependant sodium pump (McConNell and CHO 1967). The mechanism is probably the same as that for methionine. Also selenate transport may be active in rat ileum (Ardüser et al. 1985, Wolframm et al. 1985). Absorption of selenate is more rapid than that of selenite (TURNER et al. 1990). Selenate absorption probably involves a carrier-mediated mechanism, which is relatively unspecific for selenate (Wolframm et al. 1985), is dependant on $\mathrm{a} \mathrm{Na}^{+}$gradient across the intestinal membrane (ARDÜSER et al 1985), and may derive energy from $\mathrm{Na}^{+} \mathrm{K}^{+}$-ATPase (TURNER et al. 1990).

In contrast to selenomethionine, simple diffusion probably dominates in the absorption of selenite (McConnell and CHO 1965, Wolframm et al. 1985) and selenocysteine (McConnell and Cho 1965). Humaloja and MYKKÄNEN (1986) have proposed, however, that a carrier system transports selenite in the chick intestine. Furthermore, there is evidence that Se-dicysteine could be formed extracellularly from selenite and cysteine in pig (Wolframm et al. 1988) and sheep jejunum (Wolframm et al. 1987). Se-dicysteine would then be transported across the intestinal brush border by the active $\mathrm{Na}^{+}$-dependant trans- port system existing for neutral amino acids (Preston et al. 1974, Wolframm et al. 1989). L-cysteine stimulates absorption of Se from selenite probably by generation of selenodicysteine and cysteine selenopersulfide. Intracellular formation of Se-dicysteine may contribute to the stimulatory effect of L-cysteine on the uptake of Se from selenite by maintaining the concentration gradient for passive uptake of selenite (WürmLi et al. 1989).

Reduced glutathione (GSH) and $\gamma$-glutamyltransferase $(\gamma-\mathrm{GT})$ may play some role in the absorption of selenite in the rat intestine (ANUNDI et al. 1984). A large amount of GSH is excreted in the bile in rats (SIES et al. 1979, EBERLE et al. 1981) probably resulting in the formation of oxidized selenodiglutathione (GSSeSG). This would act as a substrate for $\gamma$-GT and result in the formation of amino acids and dipeptides, for which active transport mechanisms exist in intestinal cells. Selenium bound to these products might thus become available for active transport (ANUNDI et al. 1984).

\subsubsection{Factors affecting Se absorption}

The efficiency of selenium absorption apparently is not regulated by dietary selenium level (LOPEZ et al. 1968, CARY et al. 1973, Kiker and Burk 1974), although Humaloja and MYKKÄNEN (1986) reported that at a toxic Se dietary level selenium absorption tended to increase. Supplementing methionine to hamsters (McCONNEL and CHO 1967) and sulphur to sheep (Pope et al. 1979) or rats (ARDÚSER et al. 1985) tended to decrease the rate of selenium absorption although the results with sulphur are not consistent (e.g. PAULSON et al. 1966, White and Somers 1977). Some cations, especially bivalent cations like silver (RAHIM et al. 1986) and lead (MYKKÄNEN and Humaloja 1984, Neathery et al. 1987), may decrease selenium absorption when administered together with Se. However, neither $\mathrm{Cu}$ (RAHim et al 1986, Koenig et al. 1989), $\mathrm{Fe}, \mathrm{Cd}, \mathrm{Mo}, \mathrm{Mn}$ (RAhim et al. 1986) nor Co 
(van RySSEN et al. 1987) affected selenite absorption. Absorption of selenium may be decreased on low or high calcium intake (Alfaro et al. 1987), with the optimal dietary calcium level being $8 \mathrm{~g} / \mathrm{kg}$ DM for selenium absorption in the dairy cow (HARRISON and Conrad 1984b).

Vitamin A (CомBs 1976) and ascorbic acid (Combs and Pesti 1976, Сombs and Scott 1974) in chicks and ascorbic acid in rats (RAнIм 1985) increase selenium absorption, suggesting that factors which inhibit the oxidation of dietary selenium promote its absorption. In contrast to this MYKKÄNEN and Mutanen (1983) reported that moderate doses of ascorbic acid can inhibit the intestinal absorption of selenite in chicks when administered together intraduodenally. In their later study in non-fasted chicks (MYKKÄNEN and MutAnen 1986) concluded that orally administered ascorbic acid had no effect on selenium absorption, but there might be some differences between the Se sources. Lowered absorption due to ascorbic acid might be due to reduction of selenite to elemental Se (HILL 1979). Ascorbic acid status of chicks has no effect on selenium absorption (MYKKÄNEN and Mutanen 1983). The ionophores narasin and monensin have enhanced selenite absorption in steers (Costa et al. 1985).

In rat selenium absorption is enhanced with increasing age (RAGHIB et al. 1986), but the opposite has been found in sheep (GRACE and WATKINSON 1988).

\subsubsection{Resecretion of Se into intestine}

A significant amount of absorbed selenium is excreted back to the intestine in rat (IMBach and Sternberg 1967, Gregus and KlaAsSEn 1986), sheep (Hidiroglou and JENKINS 1974, LANGLANDS et al. 1986) and bovine (Symonds et al. 1981a and b). Two to three times the amount of ingested Se enters the proximal portion of the small intestine in sheep (Langlands et al. 1986). Secretion is highest in the first fifth of the small intestine (Wright and Bell 1966) or in the midjeju- num (Hidiroglou and Jenkins 1974) in sheep and in the first fifth of the small intestine in swine (Wright and BeLL 1966). Resecreted Se enters the gastrointestinal tract mainly via saliva and bile. In sheep saliva Se concentration is reported to be $0.3 \mu \mathrm{g} / \mathrm{l}$ and in bile is nearly three times higher (LANGLANDS et al. 1986). There was no correlation between Se concentration in blood and that of saliva or bile. DEJNEKA et al. (1979) reported about $2 \%$, but LANGLANDS et al. (1986) as much as $28 \%$ of a Se dose to be excreted via bile in sheep. The corresponding figures for the rat are $4 \%$ (LeVAnder and Baumann 1966) to about $6 \%$ (Imbach and Sternberg 1967) and for cattle about $2 \%$ with selenite and about $1 \%$ with selenate (Symonds et al. 1981b). Biliary excretion does not increase proportionally with dosage suggesting that the hepatobiliary transport of selenium is saturable (GREGUS and KLAASSEN 1986). The total secretion of selenite into the intestine in cattle is about $9 \%$ of the total dosage of selenite and about 14-17 \% of selenate (Symonds et al. 1981b), suggesting that digestive juice plays a major role. In rats $11 \%$ of selenite was secreted in digestive juice (IмвасH and Sternberg 1967). The major selenocompound secreted in bile is probably selenotaurocholic acid (ROSENFELD 1962). In cats $1.4 \%$ of intravenously injected ${ }^{75} \mathrm{Se}$-selenomethionine was excreted in pancreatic juice, mainly in protein-bound form (HANSON and Blau 1963).

\subsection{Metabolism and chemical forms of selenium in tissues}

Although the chemistry of selenium resembles that of sulphur in several respects, these elements have important biochemical differences and are therefore not completely interchangeable in animals. The quadrivalent $\mathrm{Se}$ in selenite tends to undergo reduction, while the quadrivalent $\mathrm{S}$ in sulfite tends to undergo oxidation. Thus Se compounds tend to be metabolized in animals to more reduced states, while S compounds tend to be oxidized (Cомвs and Combs 1984). Although the 
analogous oxyacids of Se and S have comparable strengths, the hydride $\mathrm{H}_{2} \mathrm{Se}$ is a much stronger acid than $\mathrm{H}_{2} \mathrm{~S}$. This difference is reflected in the dissociation constants of the selenohydryl group of selenocystine (pKa 5.24 ) and the sulphydryl group of cystine (pKa 8.25) (Huber and CRIDdle 1967). Whereas thiols such as cystine are mainly protonated at physiological $\mathrm{pH}$, the selenohydryl groups of selenols such as selenocystine are largely dissociated. This behavior appears to be important in the catalytic role of selenium in selenoenzymes.

\subsubsection{Selenium in erythrocytes and plasma}

Studies concerning selenium metabolism in erythrocytes are abundant and have been carried out in rats (BURK 1973, BUtLer et al. 1985), mice (SANdholm, 1973a, SANdholm 1974), chicks (JENKINS et al. 1969), humans (Burk et al. 1967, LeE et al. 1969, BurK 1974, MAS et al. 1988), sheep (Wright and BeLL 1966) and cattle (SANDHOLm 1973b, JenKins and Hidiroglou 1988). Glutathione peroxidase (GSH-Px) is the best documented selenocompound in animals. The molecular weight of this enzyme in cattle erythrocytes has been reported to be 84000 to $88000 \mathrm{U}$ (OH et al. 1974, Jenkins and Hidiroglou 1988). The role of Se in GSH-Px was first demonstrated by Rotruck et al. (1973) and Flohe et al. (1973) and the structure was described by LADENSTEIN (1979).

Plasma proteins do not bind selenium as selenite unless erythrocytes are present, suggesting that a transformation of selenite occurs within the erythrocytes (MAS et al. 1988). Exchange of selenite between plasma and the erythrocyte is a rapid process. Within one minute $50-80 \%$ of selenite selenium was accumulated inside erythrocytes in humans (LeE et al. 1969), in mice (SANDHOLM 1973a) and in rats (GASIEwiCZ and SMITH 1978). The uptake of selenite by bovine, chick and ovine erythrocytes is also rapid, but not as rapid as that of human or rat erythrocytes (JenKins 1968, JenKins and Hidiroglou 1972,
Sandholm 1973b, McMurray and Davidson 1979). In a cow at low plasma selenium concentration $(<0.2 \mathrm{mg} / \mathrm{l})$ selenite was taken up in one to two minutes by erythrocytes and thereafter the ejection exceeded the uptake. At higher selenium concentrations $(>2 \mathrm{mg} / \mathrm{l})$ the bulk of selenium remained associated with erythrocytes. At a very high selenium concentration $(200 \mathrm{mg} / \mathrm{l})$ the uptake of Se by the red blood cells was restricted (SANDHOLM 1973b). Some of selenite may stay unaltered inside the erythrocytes and extract as selenite. This happens whenever a relatively small number of erythrocytes is present (McMurray and DAvidson 1979).

The uptake of selenium by erythrocytes is dependant upon the availability of reduced glutathione (GSH) (JENKINS and Hidiroglou 1972, Sandholm 1973b, Gasiewicz and Smith 1978) or sulphydryl groups (PorTer et al. 1979) and the amount of selenium in blood (SANDHOLM 1973b). However, increased selenite concentration tends to deplete erythrocyte GSH (Gasiewicz and Smith 1978). Haemoglobin is reported to be the binding site for newly-reduced Se and thus haemoglobin would play a role in the erythrocyte uptake of selenite (MAS et al. 1988). JENKINS and Hidiroglou (1988) reported that in calves fed selenium at a dietary level of 5 ppm 35 to $40 \%$ of erythrocyte Se was in GSH-Px, $50 \%$ in haemoglobin and $5 \%$ in a selenite plus selenopolypeptide fraction $72 \mathrm{hrs}$ post dosing. In pigs Se has been reported to be distributed equally between GSH-Px and haemoglobin (XIA et al. 1985). In rhesus monkeys fed selenite $68 \%$ of erythrocyte Se was associated with GSH-Px while in animals fed selenomethionine only $34 \%$ of erythrocyte Se was in GSH-Px. In contrast, more Se was associated with haemoglobin in animals fed selenomethionine than selenite (BUTLER et al. 1990). In haemoglobin Se is retained in the globin portion (Beilstein and Whanger 1986a).

Subsequent to selenite's appearance in the erythrocyte it reacts with GSH to form selenodiglutathione (GSSeSG) (GANTHER 1968, 
SANDholm and SiPPONEN 1973). GSSeSG is further reduced by NADPH and glutathione reductase to form selenopersulphide (GSSeSH) and further to $\mathrm{H}_{2} \mathrm{Se}$ (GASIEWICZ and SMITH 1978). $\mathrm{H}_{2} \mathrm{Se}$ or a similar reduced product of GSSeSG is the final product of selenite metabolism in the rat erythrocyte. McMurray and DAvidson (1979) called this product compound $\mathrm{X}$. However, release of selenium from rat erythrocytes occurs through a different mechanism when compared to that observed for diglutathione (GSSG) (GASIEwICZ and SMIтH 1978). Selenite metabolism in animals leading to the formation of methylated selenides is believed to occur via $\mathrm{H}_{2} \mathrm{Se}$ (GANTHER and HSIEH 1974, Hsieh and Ganther 1977). $\mathrm{H}_{2} \mathrm{Se}$ is an unstable compound, which may undergo oxidation to elemental selenium (GANTHER 1971) and further, combine with tissue macromolecules such as albumin (Hsieh and Ganther 1975) or other selenocompounds. However, when receptor sites on plasma proteins exist, compound $\mathrm{X}$ is excreted from the erythrocyte to be bound to this acceptor protein. If plasma proteins are saturated compound $\mathrm{X}$ is retained by the erythrocyte and becomes attached to proteins within the erythrocyte. These processes are reversible. Binding of selenium within the erythrocyte is an alternative process and formation of protein-bound selenium in plasma is usually favored (McMURRAY and DAVIDSON 1979). In the rat $85 \%$ (GASIEWICZ and SMITH 1978) and in the sheep $90 \%$ (McMurray and Davidson 1979) of the selenium released into plasma is found to be protein-bound. The majority of this selenium is incorporated into selenocystines in polypeptides (CUMMINS and MARTIN 1967, JENKINS 1968). Incorporation of selenium into serum proteins need not be enzymatic. In addition to proteins, biologically significant sulphydryl reducing agents such as $\mathrm{CoASH}$, cysteine and GSH have also been reported to form selenotrisulphides upon reaction with selenous acids (GANTHER 1968, SANDHOLM and SiPPONEN 1973). The reaction of selenite with the thiol groups of these compounds is an important pathway through which inor- ganic selenium is initially incorporated into living systems (KICE 1981).

In contrast to selenite and selenomethionine, selenate is probably taken into the erythrocyte only by diffusion (JENKINS and Hidiroglou 1972). Even though selenite as such does not bind to plasma proteins, $\mathrm{H}_{2} \mathrm{Se}$ and GSSeSG are readily incorporated to plasma proteins even in the absence of erythrocytes (GASIEWICZ and SMITH 1978). Albumin (SANDholm 1973a, Mas et al 1988) and another protein having a molecular weight of greater than $200000 \mathrm{U}$ (MAS et al. 1988) are the initial acceptors for the selenium compound released from erythrocytes. Increasing the selenium dose has generally increased the total selenium binding to albumin (JENKINS and Hidiroglou 1988), but decreased the binding to the $\alpha$-globulins in rats and dogs (Hirooka and Galombos 1966). Jenkins et al. (1969) postulated that albumin binds selenium only when supraphysiological levels of selenite are employed. This was confirmed by HeR. MAN and McConnell (1974). Also McMurRAY and DAVIDSON (1979) found that some proteins other than albumin play an important role in the binding of selenite metabolized by erythrocytes. $\beta$-lipoprotein is suggested to be an important site for selenium attachment (SANDHOLM 1975). Only a small percentage of the total plasma selenium is identified as selenium-dependant GSH-Px (BEHNE and WOLTERS 1979). In erythrocytes, however, GSH-Px represents most of the total selenium, being $75 \%$ in sheep ( $\mathrm{OH}$ et al. 1974) and $100 \%$ in rat (BEHNE and Wolters 1979). The proportion of erythrocyte Se associated with GSH-Px is dependant on the Se source, organic forms of selenium being incorporated more efficiently into other proteins than into GSH-Px (Beilstein and Whanger 1986a, 1986b, Butler et al. 1990).

Plasma proteins are important carriers for the incorporation of selenium into lymphocytes. Uptake of protein-bound selenium by lymphocytes is three times as high as uptake of selenite. There are neither energy nor protein synthesis requirements for the uptake of 
seleno proteins or selenite by lymphocytes, but there is need for sulphydryl groups for uptake of both protein bound selenium and selenite (PORTER et al. 1979). Protein synthesis is also not needed in leucocytes for uptake of selenite (CAvalieri et al. 1967).

\subsubsection{Selenium metabolism in the liver}

The liver plays an essential role as the selenium processing center of the body. In the liver selenium is converted to compounds which are available for other organs and through which selenium is excreted from the body (BeHne and Höfer-Bosse 1984).

In several studies the plasma concentration of intravenously given selenium has decreased sharply reaching the minimum 15 to $40 \mathrm{~min}$ utes after the injection (SANDHOLM 1973b, ALLEN and Miller 1981a, Symonds et al. 1981b). During the first 30 minutes bovine liver takes up $40 \%$ of the selenium removed from the plasma (Symonds et al. 1981a, 1981b). After reaching the minimum level, the plasma selenium begins to increase due to the release of selenium from the liver back to plasma. $\alpha$ - and $\gamma$-globulins bind the selenium metabolites released from the liver (SYMONDS et al. 1981b). MOTSEnBocker and TAPPEL (1982a, 1982c) found in rat and monkey liver and in plasma a selenocysteine-containing protein, which had a short half-life. They called it selenoprotein P. Other studies have confirmed the hypothesis that this protein is serving as a selenium transportation protein from the liver to other tissues (MOTSENBOCKER and TAppel 1984, Beilstein et al. 1984, Gometz and TAPPEL 1989). A similar selenium transport protein has been identified in swine plasma (XIA et al. 1985). At a high intake of selenite Se deposition occurs mainly in the cytosol fraction of the liver, differing from muscle, kidney and testes where an excess of $\mathrm{Se}$ is deposited in the nuclear fraction (DEA. GeN and Whanger 1985).

\subsubsection{Enzymatic synthesis of selenocysteine in liver}

Synthesis of selenocysteine plays a very im- portant role in selenium metabolism. More than $80 \%$ of the selenium in selenite fed rats is found to be in the form of selenocysteine (Hawkes et al. 1983, Butler et al. 1985). The number of proteins containing selenocysteine has been estimated to be 9 to 19 in rats (HAwKEs et al. 1983), GSH-Px being the most important compound containing selenocysteine (DEAGEN and Whanger 1985).

Se dosed as selenomethionine is first deposited in liver as selenomethionine, but then is slowly converted to selenocysteine (BUTLER et al. 1985) probably through the same pathway as cysteine from methionine: selenomethionine $-\rightarrow$ Se-adenosylselenomethionine $\rightarrow$ Se-adenosylhomocysteine $\rightarrow$ selenohomocysteine $\rightarrow$ selenocystathione $-\rightarrow$ selenocysteine. These reactions are catalyzed by cystathione $\beta$-synthetase and cystathione $\gamma$-lyase (EsAKI et al. 1981, SodA et al. 1981). Selenocysteine is synthesized also from selenite (HAWKes and TAPPEL 1983). Conversion of selenite to selenocysteine to be used for the GSH-Px synthesis occurs faster than conversion to selenomethionine (BUTLER et al. 1985). However, the mechanism of selenocysteine synthesis from selenite still remains unclear. One possible pathway is the reverse of the selenocysteine lyase reaction, which would contribute selenocysteine formation from alanine and $\mathrm{H}_{2} \mathrm{Se}$ (ESAKI et al. 1985). However, no selenocysteine has been found to be synthesized from $\mathrm{H}_{2} \mathrm{Se}$ and serine. In rat liver selenocysteine, but not cysteine, is catabolized rapidly by selenocysteine lyase into alanine and $\mathrm{H}_{2} \mathrm{Se}$ (ESAKI et al. 1985). Selenocysteine is synthesized and catabolized continuously and thus the selenium retention in various tissues is in constant flux.

\subsubsection{Selenoprotein synthesis in liver}

GSH-Px and selenoprotein P are synthesized in rat liver (BURK and GREGORY 1982, Motsenbocker and TAPPEL 1982c). In ruminants, liver GSH-Px synthesis does not play a major role in selenium metabolism. Only $10 \%$ of hepatic selenium was incorpo- 
rated into GSH-Px in ruminants whilst $75 \%$ of hepatic selenium in rat liver was found in the form of GSH-Px (SUNDE et al. 1978). There exist two possible mechanisms for incorporation of selenium into GSH-Px. SUNDE and HoEKSTRA (1980 and 1981) proposed post-translational incorporation, in which organic selenium has to be converted into the inorganic form before its attachment to an amino acid residue of the GSH-Px polypeptide chain. However, this theory was criticized by HAwKES et al. (1982), who introduced translational incorporation involving selenocysteine attaching to the polypeptide chain of GSH-Px during the protein synthesis. They also found selenium-specific selenocysteyltRNA in rat liver. Selenocysteyl-tRNA was later confirmed to be synthesized from selenite in rat liver (HAWKES and TAPPEL 1983) and incorporating its selenocysteine moiety to the polypeptide chain of GSH-Px during protein synthesis.

Selenoprotein $\mathrm{P}$ is synthesized both in vitro and in vivo in the rat hepatocyte. The mechanism by which selenocysteine attaches into selenoprotein $\mathrm{P}$ is probably the same as proposed for GSH-Px (MOTSENBOCKER and TAPPEL 1982c). Hepatic synthesis of selenoprotein $\mathrm{P}$ is a rapid process and the highest concentration in plasma has been reached three hours after injection of selenium. Selenoprotein $\mathrm{P}$ is also removed rapidly from plasma to other tissues (MOTSENBOCKER and TAPPEL 1982c). Selenium deficient rats are shown to retain twice as much selenium in selenoprotein $\mathrm{P}$ when compared to selenium sufficient rats (Motsenbocker and TAPPEL 1982c). Obviously the liver prioritizes the synthesis of selenium transportation protein above that of other selenoproteins (e.g. GSH-Px). This enables an animal to maintain a sufficient level of available selenium for tissues where selenium is most needed (BURK and GREGORY 1982). In this way the liver redistributes selenium between different tissues and Se compounds in selenium deficient animals (MotSEnBocker and TAPPEL 1982c).

\subsubsection{Synthesis of methylated selenocompounds}

Selenomethionine, selenocysteine and $\mathrm{H}_{2} \mathrm{Se}$ are toxic for animals and are converted to harmless dimethyl selenide and trimethylselenonium ions (MARTIN 1973). Methylated selenocompounds are mainly produced in the liver, but the kidney also is able to synthesize dimethylselenide (GANTHER and Hsieh 1974, HSIEH and Ganther 1977), a direct precursor of trimethylselenonium ion (TMSe). Toxicity of TMSe is only one-tenth that of selenomethionine and selenite (OBERMEYER et al. 1971). The biological role of TMSe is negligible and it is excreted readily in urine (TSAY et al. 1970, Foster et al. 1986b). Methylation of selenomethionine probably arises from the synthesis of selenocysteine, which is further catalyzed to $\mathrm{H}_{2} \mathrm{Se}$ and alanine via selenocysteine lyase (ESAKI et al. 1981, 1982). $\mathrm{H}_{2} \mathrm{Se}$ then is metabolized further to TMSe. Selenocysteine probably is not first catabolized to $\mathrm{H}_{2} \mathrm{Se}$ when synthesizing TMSe (FosTER and GANTHER 1984). Precursors for dimethylselenide are $\mathrm{H}_{2} \mathrm{Se}$ or other intermediate products from the reduction of selenite. In this reaction the hydrogen of the precursors is substituted enzymatically by methyl groups (Ganther and Hsien 1974). There exist at least two different types of methyltransferases, one existing in hepatic microsomes and the other in the cytoplasm (HsIEH and Ganther 1977). If the methylation capacity is exceeded the excess of dimethylselenide is excreted via the lungs. TMSe is not an inert compound and may undergo demethylation followed by remethylation (FOSTER et al. 1986a).

\subsubsection{Selenium metabolism in kidney}

More than $99 \%$ of kidney selenium is found in the cortex and only a small fraction in the medulla (LOPEz et al. 1968). Most of the cellular selenium of goat kidney is found in the nuclear fraction (Allen and Miller 1981b). In rats about half of the kidney selenium is distributed in the cell organelles with the highest concentration found in the lyso- 
somes (MOTSEnBocker and TAPPEL 1982b). Only a small fraction of this lysosomal Se was identified chemically. XIA et al. (1985) reported most of kidney Se to be associated with GSH-Px in pigs. MOTSENBOCKER and TAPPEL (1982b) speculated that selenium in plasma selenoprotein $\mathrm{P}$ is made available for the tissues by catabolizing selenoprotein $\mathrm{P}$ in the lysosomes of the cell. Thus high lysosomal selenium content might represent intermediate products of selenoprotein $\mathrm{P}$ catabolism.

In rat kidney, specific activity of ${ }^{75} \mathrm{Se}$ was highest one hour after injection of ${ }^{75} \mathrm{Se}-\mathrm{la}$ beled selenite or selenomethionine (MILLAR et al. 1973). In the kidney selenium is rapidly incorporated into proteins and within a few hours after injection of selenite, selenate or selenomethionine most of selenium has been found in the protein fraction (MILlaR 1972, Millar et al. 1973).

At least four different selenoproteins have been discovered in the kidney. Only $10 \%$ of the selenium in the rat kidney is in the form of GSH-Px (BEHNE and Wolters 1983), with most of GSH-Px in the mitochondrial fraction (MOTSENBOCKer and TAPPEL 1982b). In addition to GSH-Px, selenoprotein-P1 and two smaller selenoproteins have been found in the kidney (MOTSENBOCKER and TAPPEL 1982b). These two smaller proteins may have a specific function in the kidney, because these selenoproteins were found neither in the liver nor testis. It seems likely that there exists some specific function for selenium in the kidney, because in the selenium-deficient sheep (LoPEZ et al. 1968) and rat (BURK et al. 1973, BEHNE and HöFER-Bosse 1984) a high proportion of selenium is retained in kidney. BozKURT and SMITH (1981) speculated that selenoproteins might have some effect against the toxicity of cadmium. It is more likely, however, that cadmium reacts with selenite, but not with selenoproteins (MOTSENBOCKER and TAPPEL 1982b).

After absorption organic Se is incorporated immediately into tissue proteins (VOKALBOREK 1980) and is not filtered by nephrons. Free selenomethionine could be filtered in the glomerulus, but is readily reabsorbed in the proximal nephron as is methionine (RoBINSON et al. 1985).

Excretion of selenium into urine with increasing dietary selenium intake is due to elevated production of organic selenium metabolites, like TMSe. In addition to TMSe, KIKER and BURK (1974) were able to demonstrate three other urinary selenium-containing products, which they called U-2, U-3 and U-4. These products were not formed in vitro from selenite. The methodology used by KIKER and BURK (1974) to identify these compounds was, however, later criticized by NAHAPETIAN et al. (1983), even though they also found at low Se intake that non-TMSe contributes most of the Se excreted in urine. TMSe was the primary selenocompound in rat urine when selenate, selenomethionine, selenocysteine, Se-methylselenocysteine or wheat selenium were fed (PAlmer et al. 1970, NAhAPETIAn et al. 1983). U-2 also was detected after all these selenium sources were fed. Some volatile selenocompounds have been detected in urine (PALMer et al. 1970), especially when organic selenium has been involved. KIKER and BURK (1974) demonstrated in vitro synthesis of some urinary compounds, which they referred to as inorganic compounds. NAHAPETIAN et al. (1983) postulated, however, that little or no selenite is excreted in urine in the rat. The first selenocompounds occurring in urine after selenite injection to rats are inorganic, but later the proportion of inorganic metabolites of selenium in urine plateaus at the level of $20 \%$ of total urinary Se in selenium sufficient rats and at $50 \%$ in selenium deficient ones.

The proportion of TMSe in urine rises dramatically with increasing selenium dose. The change was from $10 \%$ to $69 \%$ (NAHAPETIAN et al. 1983) or from $2 \%$ to $70 \%$ (MoRrIS and LeVAnder 1986) when the Se dose was increased by a factor of 100 . Thus very little TMSe is excreted with selenium deficient diets, but it is the primary excretion metabolite when the intake exceeds the requirement (KIKER and Burk 1974, Nahapetian et al. 1983). 
This probably illustrates detoxification of ingested Se (Nahapetian et al. 1983). Selenium level has effected also the excretion of U-2 (KIKER and Burk 1974). Thus selenium excretion in urine is regulated through the production of TMSe and U-2. Proportion of selenium excreted as TMSe has been smaller after dosing selenomethionine than after dosing selenate (NAHAPETIAN et al. 1983, Morris and LEVANDER 1986).

TMSe was found to be about 10 times less toxic than inorganic (selenite or selenate) and organic (selenocysteine or selenomethionine) selenium and furthermore to be an inactive compound that was almost completely recovered from urine when it was fed to Se-deficient rats (TSAY et al. 1970). In some studies, however, TMSe is found to be the major urinary metabolite of Se even at low levels of selenite administration in rats (PALMER et al. 1969, KiKer and BurK 1974, BurK 1976) indicating that TMSe is a normal product of selenite metabolism. These discrepancies may, however, reflect different routes of dosing (e.g. intravenous vs. oral). Thus a slower rate of absorbed Se entering the blood stream, as compared to that after injection, might result in differences in the extent and rate of formation of TMSe in the liver and kidney. NAHAPETIAN et al. (1983) suggested that in urine there is no free selenite, but it could be in a bound form together with other urinary metabolites, which were either neutral or negatively charged compounds.

In addition to the chemical form of $\mathrm{Se}$ and dietary Se level several other factors have been reported to affect urinary Se excretion. High intakes of vitamin $\mathrm{E}$ (HE and $\mathrm{ZHU}_{\mathrm{HU}}$ 1988) and vitamin $B_{2}$ (PARSON et al. 1985) have been shown to decrease urinary Se excretion while the opposite trend has been reported with Mn (Meng et al. 1987), sulphur containing amino acids (Greger and Marcus 1981) and sulphate (Ganther and Baumann 1962, Pope et al. 1979). The effect of sulphate was not, however, confirmed by PAULSON et al. (1966) using reasonably high dietary S content. Dietary protein content has been shown to be corre- lated positively with urinary excretion of selenite in rats (Аміот et al. 1982), but negatively in humans (GREGer and MarCus 1981). There also exist small differences in the amounts of Se compounds excreted in urine between young and adult animals. In adults the main compound has been TMSe, while in young animals Se-glutathione, selenotrisulphide and an unidentified neutral substance are predominant. However, the overall components were the same (Ostadolova et al. 1988).

\subsubsection{Selenium metabolism in the mammary gland}

Transfer of selenite into the mammary gland involves production of a reduced seleno compound in the liver followed by diffusion of this compound into mammary gland (Allen and Miller 1981a). The theory of passive diffusion is supported by the fact that after injection of ${ }^{75} \mathrm{Se}$-selenite plasma ${ }^{75} \mathrm{Se}$ concentration remains higher than milk ${ }^{75} \mathrm{Se}$ (Fuss and Godwin 1975, Allen and Miller 1981b). MAus et al. (1980) also concluded that selenite Se transfer from plasma into milk is not actively regulated by the mammary gland. However, some active transfer to the epithelial cells has been speculated to occur (Allen and Miller 1981a). Secretion into milk was highest two hours after the liver started to secrete its selenium metabolite into blood (AlLen and Miller 1981a, 1981b), and is not related to the release of the erythrocyte metabolite of Se. However, small amounts of selenite and erythrocyte metabolite are excreted in milk.

Selenite ion does not bind in vitro to cow or goat milk proteins, but in mammary secretory cells a system may exist which is able to reduce selenite to a form which could be bound to proteins. Reduced $\mathrm{H}_{2} \mathrm{Se}$ binds easily to milk proteins and binding correlates positively to milk casein content (ALLEN and Miller 1981a). Selenium is bound to milk proteins between cysteine residues as selenotrisulphide (Jenkins and Hidiroglou 1971). Sulphur in cysteine is able to form bonds both 
internally and between polypeptide chains. The selenium atom may be bound between sulphur atoms either before the formation of sulphur bonds or after breakage of sulphur bridges in re-formation (JENKINS 1968). Some selenite may also be incorporated to seleno amino acids. In sheep milk more than $3 \%$ of intraruminally dosed selenite-Se (GoDwIN et al. 1971) and also a small fraction of intravenously dosed selenite-Se (Fuss and GoDWIN 1975) were reported to be in the form of selenomethionine.

Research concerning selenomethionine metabolism in the mammary gland is more scarce than that of selenite. There are differences between these two seleno compounds, however. Much less selenium is excreted into milk after the dose of selenite than after a dose of selenomethionine (JACOBSEN et al. 1965, FusS and Godwin 1975, Khirwar and Arora 1977) or feeding natural selenium containing feeds (Condrad and Moxon 1979, Maus et al. 1980). Some authors contest these results (Jenkins and Hidiroglou 1971). The reason for high excretion of selenomethionine into milk may arise from the fact that in the course of milk protein synthesis selenomethionine substitutes for methionine (JENKINS and Hidiroglou 1971). This is supported by the finding that selenomethionine is able to attach the same transfer-RNA as methionine (McConnell and Hoffman 1972).

Selenomethionine is transferred from blood into mammary gland epithelial cells probably through some selective mechanism. In the first hours after injection of selenomethionine in sheep, selenium concentration is significantly higher in milk than in plasma. Peak concentration in milk has been measured at two hours after dosing. After ${ }^{75} \mathrm{Se}$-selenomethionine injection relatively high ${ }^{75} \mathrm{Se}$ activity was found in a methionine-rich casein fraction (Jenkins and Hidiroglou 1971). However, methionine-poor milk proteins ( $\beta$-lactoglobulin, $\alpha$-lactalbumin and albumin) also retained high specific activity of ${ }^{75} \mathrm{Se}$ after selenomethionine injection. This was supposed to be due to the ability of selenomethionine to sub- stitute both cysteine and methionine in milk proteins (JENKINS and Hidiroglou 1971).

Allen and Miller (1981b) reported specific activity of ${ }^{75} \mathrm{Se}$ to be higher shortly after injection of ${ }^{75} \mathrm{Se}$-selenite in whey proteins than in casein. Later ${ }^{75} \mathrm{Se}$ activity in casein exceeded that in whey proteins. This may be due to a different and faster pathway of Se incorporation into whey proteins than into secretory vacuoles (KeENAN and DYLEWSKI 1985). Selenium in milk is mainly in the protein fraction, and thus it could be assumed that the secretory mechanism from epithelial cells to alveoli is same as for proteins generally (Allen and Miller 1981a). Casein polypeptide chains are built in the ribosomes of the rough endoplasmic reticulum, before they are transported inside the endoplasmic reticulum. From there casein micelles are transported to the Golgi apparatus for phosphorylation. Whey proteins ( $\beta$-lactoglobulin and $\alpha$-lactalbumin) probably follow the same pathway (KEENAN and DYLEWSKI 1985). In the Golgi apparatus proteins and thus selenium containing vacuoles are formed. These vacuoles migrate towards the apical membrane and finally fuse with the membrane and release their contents into the alveolar lumen (ALLEN and Miller 1981a, Keenan and Dylewski 1985). Fat droplets are enveloped by cell membrane and thus take part of the membrane into milk. Membrane from protein secretory vacuoles replaces the cell membrane which is lost in fat secretion (KeENAN and DylewsKi 1985). Selenium in fat droplets may thus be bound to the proteins in the membranes covering these droplets (Allen and Miller 1981a).

DEBSKI et al. (1987) were able to identify $8-12$ selenoproteins in human milk. They also estimated about $30 \%$ of milk selenium to be associated with GSH-Px, with the proportion being relatively higher in goat milk than in cow milk. The proportion of casein associated Se has been reported to be $29 \%$ (DEBSKI et al. 1987), 40 \% (Yoshida et al. (1981) or $60 \%$ Matrhias et al. (1967) in cow milk and about $60 \%$ in goats (DEBSKI et al. 1987). 


\section{OBJECTIVES OF THE STUDY}

Although results concerning selenium metabolism in laboratory animals are abundant, investigations of selenium metabolism in lactating ruminants are relatively scarce. Research is mainly concentrated on inorganic selenium sources and there are only a few studies which illustrate metabolism of feed selenium.

The aim of this study was to investigate selenium metabolism in lactating cows and goats fed either sodium selenite or feed incorporated selenium. Sodium selenite was the inorganic seleno compound used in the study. It either was sprayed on growing stands and hence incorporated into plants in organic forms, mainly protein bound compounds, or it was fed or injected directly into animals. In addition selenomethionine was dosed intravenously into goats to obtain more detailed information on the metabolism of organic seleno compounds in lactating animals.

Various dietary selenium levels were employed in the study to obtain information on the effects of selenium status of the animal on the metabolism of seleno compounds either from inorganic or organic sources. The study was intended to include dietary selenium levels over the range of deficient up to toxic with particular emphasis on levels having the optimal selenium content.

The present study addresses the metabolism of selenium in tissues closely related to selenium absorption and excretion in lactating animals. 


\section{MATERIALS AND METHODS}

\subsection{Experiment 1 (goats fed Se depleted and supplemented diets)}

\subsubsection{Experimental design}

The experiment was carried out with four goats having average milk production of $1.4 \pm 0.1 \mathrm{~kg} /$ day $(\overline{\mathrm{x}} \pm \mathrm{SE})$, and body weight of $38.9 \pm 4.4 \mathrm{~kg}$. At the initiation of the experiment the goats were an average of 1.8 years old and they were in their sixth or seventh lactation month. The goats were kept in individual metabolism cages to enable quantitative collection of urine and faeces throughout the whole experiment.

Goats 1 and 4 were fed selenium depleted ( $0.05 \mathrm{mg} \mathrm{Se} / \mathrm{kg} \mathrm{DM})$ and goats 2 and 3 with selenited barley (see exp. 3, p. 29) supplemented rations $(0.22 \mathrm{mg} \mathrm{Se} / \mathrm{kg} \mathrm{DM})$. This supplementation level was chosen because our previous unpublished research had shown the optimal dietary Se content to be 0.2 to $0.4 \mathrm{mg}$ $\mathrm{Se} / \mathrm{kg}$ DM. Experimental rations were fed during the two months preceding the experiment.

The experiment consisted of three consecutive phases lasting 16, 18 and 18 days, respectively. In the beginning of the first phase all animals were given orally ${ }^{75} \mathrm{Se}$ labeled timothy grass (Phleum pratense). In the beginning of the phase II they were dosed intraruminally with ${ }^{75} \mathrm{Se}$ labeled sodium selenite and in the beginning of the phase III intravenously ${ }^{75} \mathrm{Se}$ labeled selenomethionine (Figure 1). This order for dosing was chosen to avoid high background activity remaining after the intravenous dose.

\subsubsection{Feeds, feeding and milking}

The animals were fed twice daily at 8.00 and 15.00 hrs. The rations were formulated to meet energy and protein as well as mineral standards presented in Finnish feed tables (SALO et al. 1982). The average intakes of goats 1 and 4 were $0.49 \mathrm{~kg}$ fresh grass (frozen) $0.06 \mathrm{~kg}$ hay and $0.62 \mathrm{~kg}$ barley-oatsmixture $(50: 50)$ on a dry matter basis, and in goats 2 and $30.58 \mathrm{~kg}$ fresh grass (frozen), 0.08 $\mathrm{kg}$ hay, $0.43 \mathrm{~kg}$ barley-oats-mixture (50:50) and $0.17 \mathrm{~kg}$ selenited barley (see exp. 3, p. 29) on a dry matter basis. Twenty grams of mineral mixture (Se content $0.26 \mathrm{mg} / \mathrm{kg}$ ) was given once daily mixed with concentrate to each goat.

The goats were milked twice daily and during the first days after Se doses more often as indicated in connection with sampling. At

\begin{tabular}{|c|c|c|}
\cline { 2 - 3 } \multicolumn{1}{c|}{} & $\begin{array}{c}\text { Selenium depleted } \\
\text { (Goats 1 and 4) }\end{array}$ & $\begin{array}{c}\text { Selenium supplemented } \\
\text { (Goats 2 and 3) }\end{array}$ \\
\hline Phase I, 16 days & Oral dose of ${ }^{75} \mathrm{Se}$ labeled grass \\
\hline Phase II, 18 days & Intraruminal dose of $\mathrm{Na}_{2}{ }^{75} \mathrm{SeO}_{3}$ \\
\hline Phase III, 18 days & Intravenous dose of ${ }^{75}$ Se-selenomethionine \\
\hline
\end{tabular}

Figure 1. Experimental design in experiment 1. 
each milking all milk was removed and weighed.

\subsubsection{Preparation of labeled doses}

The oral dose was produced by spraying 67.34 $\mathrm{MBq}$ of $\mathrm{Na}_{2}{ }^{75} \mathrm{SeO}_{3}$ (Amersham SCS1, $\mathrm{A}=20.65 \mathrm{MBq} / \mathrm{ml}$ ) on growing timothy grass (Phleum pratense) six days before cutting. ${ }^{75} \mathrm{Se}$-label was diluted in $20 \mathrm{ml}$ distilled water and surface tension reducer $(5 \mu$ l Citowett) was added to improve selenium uptake. About $33 \%$ of the label was retained in the grass.

The intraruminal dose of ${ }^{75} \mathrm{Se}$-selenite was prepared by adding $0.40 \mathrm{ml}(8.00 \mathrm{MBq})$ of ${ }^{75} \mathrm{Se}$-labeled $\mathrm{Na}_{2} \mathrm{SeO}_{3}$ (Amersham SCS1, $\mathrm{A}=20.65 \mathrm{MBq} / \mathrm{ml}$ ) to $50 \mathrm{ml}$ distilled water. The intravenous dose was prepared by adding $0.56 \mathrm{ml}(12.80 \mathrm{MBq})$ of ${ }^{75} \mathrm{Se}$-labeled selenomethionine (Amersham SC12, $\mathrm{A}=22.92$ $\mathrm{MBq} / \mathrm{ml}$ ) to $25 \mathrm{ml}$ of $0.9 \% \mathrm{NaCl}$ (final concentration $0.51 \mathrm{MBq} / \mathrm{ml})$.

\subsubsection{Introduction of doses}

The oral dose of timothy grass was offered in the morning before feeding animals, refusals were weighed and their ${ }^{75} \mathrm{Se}$ activity was determined. Dose was 2.87, 3.16, 3.23 and 2.77 MBq for goats 1, 2, 3 and 4, respectively. The intraruminal dose of ${ }^{75} \mathrm{Se}$-selenite (1.60 MBq) was injected through the rumen wall and the syringes were flushed twice with distilled water to ensure that the entire dose of label was introduced into the rumen.

For the intravenous dose the goats were catheterized in Vena jugularis (Cavafix 1.4 $\mathrm{mm}$ catheter). ${ }^{75} \mathrm{Se}$-selenomethionine at a dose of $2.56 \mathrm{MBq}$ was introduced through the catheters and to ensure proper flushing of the catheter syringes were filled twice with blood drawn from the catheter and then reemptied into the vein.

\subsubsection{Sampling}

During phases I and II blood samples were taken from Vena jugularis in $10 \mathrm{ml}$ hepa- rinized Vacutainer tubes and put immediately in ice. All milk, urine and faeces were collected and weighed throughout the whole experiment. The goats were milked twice daily, and urine and faeces were collected twice daily or at times indicated and sampled representatively. During phase I blood, milk, urine and faecal samples were taken at 0, 2 (only blood), $4,8,14,21,28,36,45,52,69,77$ (only milk), 92, 116 (only milk, urine and faeces), 140, 188, 236, 332 and $380 \mathrm{hrs}$ post dosing.

During phase II blood samples were taken at $0,4,8,14,22,30,54,94,142,190,262$, 334 and $430 \mathrm{hrs}$ post dosing. Milk urine and faecal samples were taken at $0,4,8,14,22$, 30, 46, 54, 70, 77 (only milk), 94, 118, 142, 166, 190, 214, 262, 334 and 430 hrs post dosing.

Blood samples during the first two days of phase III were taken through the catheters. The first $2 \mathrm{ml}$ of blood was discarded and thereafter $10 \mathrm{ml}$ of blood was taken with a heparinized syringe. Finally about $2 \mathrm{ml}$ of heparinized (5 IU heparin/ml, final concentration) sterile physiological saline was injected through the catheter to avoid clotting. After removing the catheters blood samples were taken in vacutainer tubes as during phases I and II. During phase III blood samples were taken at $0,0.17,0.33,0.5,0.75,1$, $1.5,2,4,7,10,20,34,46,77,101,166,214$, 262 and 334 hrs post dosing. Milk, urine and faecal samples were taken at $0,1.5$ (only milk and urine), 4, 7, 10, 20, 28, 34, 46, 53, 70, 77, 94, 101 (only milk), 118, 142, 166, 214, 262 and $334 \mathrm{hrs}$ post dosing.

Hair samples were shaved from rear and back at the initiation of the experiment and thereafter at the end of each phase and 29 days after the last dose.

\subsubsection{Laboratory analyses}

Radioactive samples were counted with a 1280 Ultro-Gamma (LKB-Wallac Ltd., Finland) automatic gamma counter with $3^{\prime \prime} \times 3^{\prime \prime}$ $\mathrm{NaJ}(\mathrm{Tl})$ hollow crystal for 10 minutes or for 10000 counts. 
Blood samples were centrifuged $(550 \times \mathrm{g}, 10$ min) to separate plasma and erythrocytes. Hematocrit in whole blood was determined by centrifuging samples at $13000 \times \mathrm{g} 5.5$ for minutes. In the case of inadequate volume blood was diluted with $0.9 \% \mathrm{NaCl}$. Radioactive assays were done in singlet for erythrocytes, duplicate for plasma and triplicate for milk and urine in the volume of $2.5 \mathrm{ml}$. For the radioactive determination of faeces, $70 \mathrm{~g}$ of faeces and $130 \mathrm{~g}$ of distilled water were homogenized in Stomacher 400 homogenizer (2 min mixing). For the determinations $2.5 \mathrm{~g}$ of homogenate was weighed in triplicate. Faecal samples were corrected for different geometry in counting.

Hair samples were ashed in vacuum at $50^{\circ} \mathrm{C}$ in oxygen flow for four hours in a Tracerlab LTA-600 asher. Ash was dissolved in 4-N HCl and diluted with distilled water for assay. Timothy grass was dried at $60^{\circ} \mathrm{C}$ and ashed in the same way as hair samples.

Feed selenium content was determined by hydride method (SAari and PaAso 1980). Electrothermal atomic absorption spectrometric method was used for milk and erythrocyte assays (Kumpulainen et al. 1983) and for plasma assays (Alftan and Kumpulainen 1982). Feed chemical composition was determined by standard methods, and milk fat and protein content by standard NIR-method.

\subsubsection{Calculations and statistical analyses}

Values for ${ }^{75} \mathrm{Se}$-activity for milk, blood, urine and faeces were interpolated for days when no samples were taken. All the values were corrected for decay. Values during the phases II and III were corrected for background from the preceding doses by extrapolating excretion curves of the preceding phase over the following phase and subtracting background values from the determined values.

For calculating blood volume the value of $0.07 \mathrm{l} / \mathrm{kg}$ live weight was assumed (KoLB 1967).

For calculating true absorption of ${ }^{75} \mathrm{Se}$ en- dogenous excretion in faeces during the phase III was used.

True absorption $=(100-F) /\left(100-F_{e}\right)$;

$\mathrm{F}=$ proportion of ${ }^{75} \mathrm{Se}$ actually excreted in faeces,

$F_{e}=$ proportion of endogenous ${ }^{75} \mathrm{Se}$ from absorbed ${ }^{75} \mathrm{Se}$ (based on results during the phase III)

Figures were produced using Harvard Graphics programme with curve linear fitting. Standard errors were calculated based on actual values resulting in some inaccuracy in expressing them as deviations from the curve; they are therefore given as deviations from the actual values. Rate constants (k-values) were calculated by using a graphic curve analysis technique ("curve peeling", SHIPLEY and CLARK, 1972). Values on the linear declining portion of the line were determined by the linear regression equation $(y=a-b t$, where $\mathrm{t}=$ time: linear, and $\mathrm{y}={ }^{75}$ Se-activity: $\ln$ ). Transit time (TT) expressing time for the first appearance of ${ }^{75} \mathrm{Se}$ in the samples (Grovum and Williams, 1973) was calculated according to equation (1), time for increasing ${ }^{75} \mathrm{Se}$ activity from 0 to a maximum (T) according to equation (2) and total mean retention time (TMRT) according to Grovum and PhiLLIPS (1973) by using equation (3).

(1) $\mathrm{TT}=\frac{\ln \left(\mathrm{A}_{2}\right)-\ln \left(\mathrm{A}_{1}\right)}{\mathrm{k}_{2}-\mathrm{k}_{1}}$,

where $A_{1}$ and $A_{2}$ are intercept values for ${ }^{75} \mathrm{Se}$ activity in the samples, and $k_{1}$ and $k_{2}$ are rate constants associated with the kinetics of ${ }^{75} \mathrm{Se}$ in the body.

(2)

$$
\mathrm{T}=\frac{\ln \left(\mathrm{k}_{2}\right)-\ln \left(\mathrm{k}_{1}\right)}{\mathrm{k}_{2}-\mathrm{k}_{1}}
$$

$$
\text { TMRT }=T T+1 / k_{1}+1 / k_{2}+1 / k_{3}
$$

Thus time for maximum excretion was defined as $T T+T$. Half-lives $\left(T_{1 / 3}\right)$ are expressed based on values for $k_{3}$ (or the slowest 
component within scope of determination) and were calculated as $\ln 2 / \mathrm{k}_{3}$ (SHIPLEY and CLARK, 1972).

Differences in rate constants between the selenium levels were tested by analysis of variance, differences in excretion of ${ }^{75} \mathrm{Se}$-label were analyzed by split-plot analyses of variance (SNEDECOR and COCHRAN 1980) using the following model:

$\mathrm{Y}_{\mathrm{ijkl}}=\mu+\mathrm{L}_{\mathrm{i}}+\mathrm{e}_{\mathrm{ij}}+\mathrm{T}_{\mathrm{k}}+(\mathrm{LT})_{\mathrm{jk}}+\mathrm{e}_{\mathrm{ijkl}}$,

where $L$ and $T$ are selenium level and time effects,

$e_{i j}$ the main plot error and $e_{i j k l}$ the subplot error.

Differences between the selenium levels in overall excretion of ${ }^{75} \mathrm{Se}$-label within the path and differences between regression coefficients on slopes of excretion curves were tested by t-test (SoKal and Rohlf 1981).

\subsection{Experiment 2 (goats fed diets supplemented with sodium selenite or selenited barley)}

\subsubsection{Experimental design}

The details of animal housing, sampling and analyses during experiment 2 were similar to experiment 1 . Four goats housed in individual metabolism cages with an average milk production of $1.0 \pm 0.1 \mathrm{~kg} / \mathrm{d}$ and an average body weight of $35 \mathrm{~kg}$ were involved the experiment. The goats were in their first lactation and were five months postpartum at the initiation of the experiment.

The source of selenium for goats 1 and 3 was a sodium selenite preparation (see exp. 3, p. 29) given with concentrate $(0.38 \mathrm{mg} \mathrm{Se} / \mathrm{kg}$ DM), and for goats 2 and 4 was selenited barley (see exp. 3, p. 29) at level of $0.34 \mathrm{mg} \mathrm{Se} / \mathrm{kg}$ DM. The goats were fed the experimental rations for two months preceding the experiment.

The experiment consisted of two phases lasting 28 days each. At the beginning of phase I the animals were given a ${ }^{75} \mathrm{Se}$-labeled dose intraruminally (goats 1 and 3) as $\mathrm{Na}_{2}{ }^{75} \mathrm{SeO}_{3}$ or orally (goats 2 and 4 ) as ${ }^{75} \mathrm{Se}$-labeled grass. In the beginning of phase II the goats were dosed intravenously with ${ }^{75} \mathrm{Se}-$ labeled sodium selenite (goats 1 and 3 ) or ${ }^{75}$ Se-labeled selenomethionine (goats 2 and 4) (Figure 2). This order for dosing was chosen to avoid high background remaining after the intravenous dose. This also made possible the introduction of a dose containing high ${ }^{75} \mathrm{Se}$ activity, because milk collected after the I.V. dose was used in other research.

\subsubsection{Feeds, feeding and milking}

Feeding of the animals was similar to experiment 1 and was as follows: fresh grass (frozen) $0.2 \mathrm{~kg}$, hay $0.4 \mathrm{~kg}$, oats $0.3 \mathrm{~kg}$ and barley $0.2 \mathrm{~kg}$ on a dry matter basis. Mineral mixture (Se content $0.26 \mathrm{mg} / \mathrm{kg}$ ) was offered twice daily. Average daily consumption of mineral mixture for goats $1,2,3$ and 4 was $8.8 \mathrm{~g}, 13.7 \mathrm{~g}, 7,7 \mathrm{~g}$ and $10.7 \mathrm{~g}$, respectively. The goats were milked as in experiment 1 . To obtain a reliable excretion pattern in milk during the first four hours of phase II oxytocin was injected via Vena jugularis prior to milking.

\begin{tabular}{|c|c|c|}
\hline Dietary Se source & $\begin{array}{c}\text { Inorganic } \\
\text { (goats 1 and 3) }\end{array}$ & $\begin{array}{c}\text { Organic } \\
\text { (goats 2 and 4) }\end{array}$ \\
\hline Phase I, 28 days & $\begin{array}{c}\text { Intraruminal dose } \\
\mathrm{Na}_{2}{ }^{75} \mathrm{SeO}_{3}\end{array}$ & $\begin{array}{c}\text { Oral dose } \\
\text { 75Se-labeled grass }\end{array}$ \\
\hline Phase II, 28 days & $\begin{array}{c}\text { Intravenous dose } \\
\mathrm{Na}_{2}{ }^{75} \mathrm{SeO}_{3}\end{array}$ & $\begin{array}{c}\text { Intravenous dose } \\
\text { 7s Se-selenomethionine }\end{array}$ \\
\hline
\end{tabular}

Figure 2. Experimental design in the experiment 2. 


\subsubsection{Preparation of labeled doses}

The intraruminal ${ }^{75} \mathrm{Se}$-dose for the goats 1 and 3 was prepared by adding $0.37 \mathrm{ml}$ (7.41 $\mathrm{MBq}$ ) of ${ }^{75} \mathrm{Se}$-labeled $\mathrm{Na}_{2} \mathrm{SeO}_{3}$ (Amersham $\mathrm{SCS} 1, \mathrm{~A}=20.65 \mathrm{MBq} / \mathrm{ml}$ ) and $0.5 \mathrm{ml}$ of 0.01 $\mathrm{M} \mathrm{Na} \mathrm{SeO}_{3}$ to $19.13 \mathrm{ml}$ distilled water.

The oral dose for the goats 2 and 4 was produced by spraying $24.16 \mathrm{MBq}$ of ${ }^{75} \mathrm{Se}$ labeled $\mathrm{Na}_{2} \mathrm{SeO}_{3}$ on growing Italian ryegrass (Lolium multiflorum) one week before the third cutting. ${ }^{75}$ Se-label was diluted in $20 \mathrm{ml}$ distilled water and surface tension reducer ( $5 \mu$ l Citowett) was added to improve selenium uptake. About $65 \%$ of the label was retained in the grass. Italian ryegrass was grown in a green house in a $0.2 \mathrm{~m}^{2}$ pot.

The intravenous dose was prepared for the goats 1 and 3 by adding $0.30 \mathrm{ml}(6.20 \mathrm{MBq})$ of ${ }^{75} \mathrm{Se}$-labeled $\mathrm{Na}_{2} \mathrm{SeO}_{3}$ to $12 \mathrm{ml}$ of $0.9 \%$ $\mathrm{NaCl}$ (final concentration $0.51 \mathrm{MBq} / \mathrm{ml}$ ), and for the goats 2 and 4 by adding $0.37 \mathrm{ml}{ }^{75} \mathrm{Se}$ labeled L-selenomethionine (Amersham SC12, $\mathrm{A}=22.92 \mathrm{MBq} / \mathrm{ml}$ ) to $16 \mathrm{ml}$ of $0.9 \% \mathrm{NaCl}$ (final concentration $0.52 \mathrm{MBq} / \mathrm{ml}$ ).

\subsubsection{Introduction of doses}

The intraruminal dose of ${ }^{75} \mathrm{Se}$-selenite $\mathbf{( 3 . 5 2}$ $\mathrm{MBq}$ ) for goats 1 and 3 was injected through the rumen wall. The oral dose for goats 2 (3.65 $\mathrm{MBq})$ and $4(3.62 \mathrm{MBq})$ was offered in the morning before feeding. Introduction of the intraruminal dose for goat 1 failed as the dose was probably introduced into the rumen or abdominal wall. The results from this goat were thus excluded from further analysis.

For introducing the intravenous dose the goats were catheterized in Vena jugularis (Cavafix $1.4 \mathrm{~mm}$ catheter) $20 \mathrm{hrs}$ before dosing. The dose for goats 1 and 3 was 2.52 $\mathrm{MBq}$, and for goats 2 and 4 was $2.59 \mathrm{MBq}$. After dosing the syringes were filled twice with blood drawn through the catheter and reemptied into the vein to ensure proper flushing of the catheter.

\subsubsection{Sampling}

Blood, milk, urine and faecal samples were taken as described in connection with experiment 1. During phase I blood samples were taken at 1, 3, 6, 10, 20, 27, 34, 46, 144, 216, 312, 504 and 672 hrs post dosing, and milk, urine and faecal samples at 1 (only urine), 3 (only milk and urine), 6, 10, 20, 27, 34, 34, $46,54,70,78,96,120,144,168,216,312,384$, 512 and 672 hrs post dosing.

During phase II blood samples were taken at $0,1,2,4,8,15,30,45,60,90$, and $120 \mathrm{~min}$, and at $3,4,6,10,21,27,33,46,54,72,144$, 240, 408, and 672 hrs. Milk samples were taken at $0,1,2,3,4,6,10,21,27,33,46$, $54,72,96,120,192,240,336,384,512$, and $672 \mathrm{hrs}$. Urine and faecal samples taken at 0 , 3,6 and $10 \mathrm{hrs}$ and thereafter at the same time as milk samples.

Hair samples were shaved from rear and back at the initiation of the experiment, at days 13 and 27 during phase I, and at days 7 and 14 during phase II. The hair shaved on respective days was weighed and the shaved area measured and quantity of hair $\mathrm{cm}^{-2} \mathrm{de}$ termined.

\subsubsection{Laboratory analyses, calculations and statistical analyses}

Analyses were carried out as described in experiment 1 with the exceptions of centrifuging of blood samples 10 minutes for $1200 \times \mathrm{g}$, and analyzing hematocrit in addition to whole blood from the erythrocyte suspension.

The results were calculated as described in experiment 1 . Erythrocyte ${ }^{75} \mathrm{Se}$-counts were corrected for plasma contamination using erythrocyte hematocrit values and plasma ${ }^{75}$ Se-counts.

${ }^{75} \mathrm{Se}$ retained in hair was calculated assuming equal hair growth rate over the whole body and surface area of the body $\left(\mathrm{m}^{-2}\right)$ :

$\mathrm{A}=0.12 \times \mathrm{W}^{0.66}$,

$\mathrm{W}=$ live weight $(\mathrm{kg})$ (LLOYD et al. 1978).

Statistical analyses were carried out as described in connection with experiment 1 (see chapter 4.1.7., p. 26). 


\subsection{Experiment 3 (dairy cows fed diets supplemented with sodium selenite or selenited silage)}

\subsubsection{Experimental design}

The experiment involved all dairy cows at the Suitia experimental farm. Cows were housed in a free-stall barn. The experimental design was a $2 \times 2$ factorial, with sodium selenite and selenited silage as main effects (during period $\mathrm{V}$, selenited barley, Table 1). There were thus four experimental groups:

Group 1: No sodium selenite

Group 2: Sodium selenite added $>$ Control silage

Group 3: No sodium selenite

Group 4: Sodium selenite added Selenited silage

Only cows having records from at least four periods were included analyses. Total number of cows included in the analyses was 48 of which 45 were Friesians and 3 were Ayrshires. The cows were distributed in the groups as follows: group 1: 14, group 2: 11, group 3: 11 and group 4: 12 animals.

The whole experiment consisted of six periods with different levels of selenium intake. During the two months preceding the experiment the cows were fed to meet requirements. The periods are shown in Table 1 .

Table 1. Experimental periods and the selenium content of the diet in experiment 3 :

\begin{tabular}{cccccc}
\hline \multirow{2}{*}{$\begin{array}{c}\text { Group } \\
\text { period }\end{array}$} & Days & \multicolumn{4}{c}{$\begin{array}{c}\text { Dietary selenium } \\
(\mathrm{mg} / \mathrm{kg}\end{array}$} \\
\cline { 3 - 6 } & & $1^{1}$ & $2^{2}$ & $3^{3}$ & $4^{4}$ \\
\hline I & $1-14$ & 0.20 & 0.31 & 0.21 & 0.21 \\
II $_{\text {III }}$ & $15-70$ & 0.07 & 0.17 & 0.20 & 0.29 \\
IV & $71-147$ & 0.08 & 0.42 & 0.45 & 0.78 \\
V & $148-308$ & 0.06 & 0.68 & 1.20 & 1.81 \\
VI & $309-420$ & 0.03 & 0.11 & 0.09 & 0.17 \\
\hline
\end{tabular}

1 control group, no added $\mathrm{Se},(\mathrm{n}=14)$

2 sodium selenite as source of $\mathrm{Se},(\mathrm{n}=11)$

${ }^{3}$ selenited silage (or selenited barley during the period V) as source of $\mathrm{Se},(\mathrm{n}=11)$

${ }^{4}$ sodium selenite and selenited silage (selenited barley) as source of $\mathrm{Se},(\mathrm{n}=12)$

5 standardization period, feeding was adjusted to meet requirements

${ }^{6}$ days 260-308 are excluded from further analysis, because of unequal quality of roughage among groups.

\subsubsection{Preparation of selenited feeds}

Selenited silage was produced by spraying sodium selenite on growing grass one week before cutting. Selenium used per hectare was $5 \mathrm{~g}, 3 \mathrm{~g}$ and $4 \mathrm{~g}$ for the $1 \mathrm{st}$, 2nd and 3rd cutting, respectively. Silage was slightly prewilted (DM content between 23 and $30 \%$ ). A more detailed description of the silage preparation is presented elsewhere. Control silage was made on the same days with the same method as selenited silage, only without spraying selenite. Selenited barley was produced by spraying $100 \mathrm{~g} \mathrm{Se} / \mathrm{ha}$ as sodium selenite on growing barley when coming into axe.

Sodium selenite was fed as a preparation manufactured by Kemira Ltd. The preparation was produced by mixing sodium selenite with feed grade lime and granulated using bentonite. The final content of selenium in the preparation was predicted to be $100 \mathrm{mg} / \mathrm{kg}$ (measured content $116 \mathrm{mg} \mathrm{Se} / \mathrm{kg}$ ).

\subsubsection{Feeding, dietary composition and production}

The feeding was based on wilted silage. Both silage and hay were given ad libitum and the cows had free access to them during the whole day. Hay consumption was, however, less than one $\mathrm{kg}$ per day. Concentrate : roughage ratio was on average $35: 65$ on a dry matter basis. Half of the cows were given concentrates $0.4 \mathrm{~kg} / \mathrm{kg}$ FCM exceeding $5 \mathrm{~kg}$ milk production and protein according to standards (SAlo et. al. 1982). The other half of the animals in each group were fed according to the flat rate system (see TuOri and PoutialNEN, 1982) i.e. fixed concentrate level at a maximum of $6 \mathrm{~kg} / \mathrm{d}$ including $1.5 \mathrm{~kg} / \mathrm{d}$ protein supplement during the first six lactation weeks and thereafter $0.5 \mathrm{~kg} / \mathrm{d}$ until 100 days after calving. After that the feeding pattern was changed to standard feeding (periods IIV) or concentrates were reduced to $3 \mathrm{~kg} / \mathrm{d}$ (periods V-VI). An average concentrate mixture contained $46.5 \%$ oats, $46.5 \%$ barley, $3.7 \%$ molassed beet pulp, $0.5 \%$ urea and 
$2.8 \%$ mineral mixture (Ca: P-ratio $2.5: 1$ ). In addition the cows were given daily $200 \mathrm{~g}$ of mineral mixture per cow on the top of the silage.

Roughage was given separately for each group. Refusals were removed and weighed daily. Concentrate, protein supplement, selenited barley (during period V), and selenium preparation were given individually twice daily. Concentrate refusals were weighed at each feeding time and selenium preparation refusals were estimated.

Dietary selenium originating from mineral feeds (MSe) including the selenium preparation and the commercial mineral mixture is presented in Table 2. This selenium is considered inorganic selenium in the later discussion, even though no chemical analyses of the selenium forms in the feeds were done. Selenium in energy and protein feeds is called "ffeed selenium", (FSe) and regarded as organic selenium. The content of selenium and of other minerals in feeds used in the experiment 3 are presented in Appendix 2. The highest dietary Se content fed to the cows was $2.4 \mathrm{mg} / \mathrm{kg} \mathrm{DM}$ and was thus close to the toxic level (UNDERWOOD 1981), but no symptoms of toxicity were observed.

The average dietary mineral and trace element content are presented in Table 3 . Higher $\mathrm{Ca}$ content in the groups 2 and 4 was mainly
Table 3. Average dietary mineral and trace element content in cows fed various Se diets (for group explanation see Table 1, p. 29).

\begin{tabular}{|c|c|c|c|c|c|}
\hline & \multicolumn{4}{|c|}{ Group } \\
\hline & & 1 & 2 & 3 & 4 \\
\hline $\mathrm{Ca}$, & $\mathrm{g} / \mathrm{kg} \mathrm{DM}$ & 8.8 & 9.4 & 8.3 & 9.0 \\
\hline $\mathrm{P}$ & $\mathrm{g} / \mathrm{kg} \mathrm{DM}$ & 4.5 & 4.6 & 4.8 & 4.7 \\
\hline $\mathrm{Mg}$, & $\mathrm{g} / \mathrm{kg} \mathrm{DM}$ & 2.2 & 2.2 & 2.2 & 2.2 \\
\hline & $\mathrm{g} / \mathrm{kg} \mathrm{DM}$ & 1.8 & 1.8 & 2.0 & 2.0 \\
\hline $\mathrm{Fe}$, & $\mathrm{mg} / \mathrm{kg} \mathrm{DM}$ & 680 & 650 & 550 & 580 \\
\hline $\mathrm{Zn}$, & $\mathrm{mg} / \mathrm{kg} \mathrm{DM}$ & 89 & 95 & 90 & 86 \\
\hline
\end{tabular}

due to the high content of $\mathrm{Ca}$ in the selenium preparation ( $370 \mathrm{~g} / \mathrm{kg} \mathrm{DM})$. During phase IV, when the allotment of the selenium preparation was greatest, groups 2 and 4 received $18 \%$ of their $\mathrm{Ca}$ intake in this supplement. Variation in mineral and trace element content between the periods was great (see Appendix 3).

Milk production was recorded twice daily on five days in a week with an accuracy of 0.1 $\mathrm{kg}$. Cows were weighed at four week intervals before the afternoon feeding and one day after calving.

Average feed intake was $16.6,17.4,16.8$ and $16.4 \mathrm{~kg} \mathrm{DM} / \mathrm{d}$, live weight $585,583,564$ and $563 \mathrm{~kg}$, and milk production $20.2,22.2$, 21.0 and $19.7 \mathrm{~kg} / \mathrm{d}$ in the groups $1,2,3$ and 4 , respectively. More detailed information will be published later.

Table 2. Mineral selenium (MSe) and feed selenium (FSe) intake (mg/kg DM) ${ }^{1}$ in cows fed various Se diets (for group explanation see Table 1, p. 29).

\begin{tabular}{|c|c|c|c|c|c|c|c|c|}
\hline \multirow[t]{3}{*}{ Period } & \multicolumn{8}{|c|}{ Group } \\
\hline & \multicolumn{2}{|c|}{1} & \multicolumn{2}{|c|}{2} & \multicolumn{2}{|c|}{3} & \multicolumn{2}{|c|}{4} \\
\hline & MSe & FSe & MSe & $\mathrm{FSe}$ & MSe & $\mathrm{FSe}$ & MSe & $\mathrm{FSe}$ \\
\hline II & 0.005 & 0.069 & 0.103 & 0.083 & 0.005 & 0.219 & 0.102 & 0.183 \\
\hline III & 0.005 & 0.064 & 0.349 & 0.098 & 0.005 & 0.449 & 0.381 & 0.503 \\
\hline IV & 0.006 & 0.056 & 0.701 & 0.074 & 0.005 & 1.168 & 0.615 & 1.242 \\
\hline V & 0.005 & 0.024 & 0.108 & 0.033 & 0.007 & 0.116 & 0.096 & 0.099 \\
\hline VI & 0.006 & 0.035 & 0.005 & 0.034 & 0.005 & 0.036 & 0.007 & 0.031 \\
\hline
\end{tabular}

1 Mineral selenium includes Se from commercial mineral mixture and selenium preparation, and feed selenium Se from the rest of the feeds.

Proportion of inorganic and organic Se during period I are not given because of the relatively high proportion of Se originating from protein concentrate, which contained an inorganic Se component in addition to natural feed selenium. 


\subsubsection{Sampling}

During the first four periods quality and ensiling losses of silage were monitored by the buried bag method described by EtTALA et. al. (1972). Total number of sacks was 53. During the fifth and sixth periods silage was sampled weekly. Barley and oats were sampled before grinding and hay was sampled approximately every two months. Protein supplement, mineral mixture and molassed beet pulp were sampled once for each set of these feeds purchased. Selenited barley and selenite preparation were sampled once.

Milk was sampled at four week intervals for fat and protein content and somatic cell count. Milk samples for selenium determinations and blood samples were taken on days 7, 14, 42, $70,147,259,420$ and 539. Blood samples were taken before feeding from Vena jugularis. Samples for haemoglobin, hematocrit, whole blood GSH-Px and selenium were taken in $5 \mathrm{ml}$ EDTA tubes and samples for the rest of determinations into heparinized $20 \mathrm{ml}$ tubes.

\subsubsection{Analytical methods}

Dry matter content of feeds was determined by oven drying at $103^{\circ} \mathrm{C}$ for $24 \mathrm{~h}$. Samples for analysis were dried in vacuum at $50^{\circ} \mathrm{C}$ for two to three days and milled through a $1 \mathrm{~mm}$ screen. Feed analyses were made according to standard procedures. Silage DM content was corrected for volatile losses by adding 1.4 percent units to the measured DM content (HuIDA et al. 1986). Selenium in feeds was determined by hydride method, calcium, magnesium, iron and zinc by atomic absorption and phosphorus by vanadium molybdate method as described by SAARI and PAASO (1980). Sulphur was determined by LECO-132 sulphur analyzer. In earlier studies these minerals and trace elements are speculated to interfere with Se metabolism (Rodvien et al. 1974, Pope et al. 1979, HARrison and ConRAD 1984b, RAHIM et al. 1986). In vitro digestibility (TILLEY and TERry 1963) was measured in all roughage samples. Net energy in fattening feed units and digestible crude protein were calculated according to chemical composition and digestibility coefficients taken from Finnish feed tables (SALo et. al 1982).

Milk fat and protein content and somatic cell count were determined with standard NIR-technique. Milk and whole blood selenium was determined by hydride method as described by TYKKYLÄINEN et al. (1985) and plasma selenium by electrothermal atomic absorption spectrometric method (ALFTAN and Kumpulainen, 1982).

GSH-Px in whole blood and plasma (on days 7, 70 and 147) were determined by modified GúNZLER (1974) method as described by SANKARI (1985), hemoglobin by cyanomethemoglobin method (van KAMPEN and Z IJLSTRA 1961), and hematocrit as described in experiment 1. Aspartate aminotransferase (ASAT), alkaline phosphatase (AP), creatine kinase (CK) (ANON. 1974), and $\gamma$-glutamyl transferase $(\gamma$-GT) (Anon. 1976) were determined according to the recommendations of the Committee on Enzymes of the Scandinavian Society. Plasma glucose was determined by otoluidine method (HYvärINEN and NIKKILÄ 1962), total protein by biuret reaction (HENRY et al. 1974), albumin by bromcresol green method (BARTHOLOMEW and Delaney 1964), cholesterol by enzymatic colorimetric method (TAlKe and Schubert 1965) and plasma Ca, $\mathrm{P}$ and $\mathrm{Mg}$ with GILFORD 3500 Auto Analyzer. Plasma tocopherols on days 14 and 259 (four animals in each group) were determined by a high performance liquid chromatographic method (PiIRonen et al. 1985).

\subsubsection{Calculations and statistical analyses}

Erythrocyte Se content and GSH-Px-activity were calculated using hematocrit value, and whole blood and plasma Se/GSH-Px values. For calculating blood volume 0.077 1/kg live weight (KolB 1967) and for estimating mammary uptake of Se from plasma 5001 blood circulating through the mammary gland per one liter milk produced (RooK and THOMAs 1983) were assumed. 
Differences in blood parameters and milk Se content were analyzed by split-plot analyses of variance using the following model:

$\mathrm{Y}_{\mathrm{ijkl}}=\mu+\mathrm{D}_{\mathrm{i}}+\mathrm{e}_{\mathrm{ij}}+\mathrm{P}_{\mathrm{k}}+(\mathrm{DP})_{\mathrm{jk}}+\mathrm{e}_{\mathrm{ijk} \mathrm{k}}$,

where $\mathrm{D}$ and $\mathrm{P}$ are diet and period effects, $e_{i j}$ the main plot error and $e_{i j k l}$ the subplot error.

Significance levels given in the tables were obtained by analysis of variance separately within each period, and differences between the groups using Q-test (SNEDECOR and Cochran 1980). 


\section{RESULTS}

\subsection{Experiment 1}

\subsection{1. ${ }^{75}$ Se given orally in selenited grass}

\subsubsection{Excretion of ${ }^{75} \mathrm{Se}$}

During the 16 day follow-up period (phase I) after the oral ${ }^{75} \mathrm{Se}$ dose, depleted goats excreted $6.7 \pm 1.0(\overline{\mathrm{x}} \pm \mathrm{SE}), 5.7 \pm 1.6$ and $37.5 \pm$ $4.2 \%$ of the dose in milk, urine and faeces, respectively. Selenium supplemented goats excreted during the same time interval 8.2 \pm 1.1 , $15.2 \pm 2.6$ and $38.5 \pm 0.3$, respectively. Total excretion was thus $49.9 \pm 6.8$ for depleted and $61.9 \pm 1.1$ for selenium supplemented goats. Only excretion in urine was significantly different $(\mathrm{p}<0.05)$ in Se depleted and supplemented groups.

Maximum excretion in milk occurred at $25.7 \pm 0.1$ and $23.3 \pm 0.2$ hrs after dosing in selenium depleted and supplemented goats, respectively. The difference in maximum values was significant $(p<0.05$, Figure $3 a)$. Variation in ${ }^{75} \mathrm{Se}$ excretion in urine was great, mostly due to uneven volume of urine $(\mathrm{ml} / \mathrm{h})$ voided during the first two days when sampling interval was frequent. However, maximum ${ }^{75} \mathrm{Se}$ activity was reached in less than one day (Figure 3b) and rate of excretion of ${ }^{75} \mathrm{Se}$ tended to be lower for depleted goats than for supplemented ones (1.9 vs. $3.6 \%$ of dose/d). Maximum faecal ${ }^{75} \mathrm{Se}$ losses occurred at $31.2 \pm 1.4 \mathrm{hrs}$ and $25.9 \pm 1.2 \mathrm{hrs}$ after dosing (Figure 3c) and total ${ }^{75} \mathrm{Se}$ losses at $28.1 \pm 1.2 \mathrm{hrs}$ and $22.8 \pm 0.2 \mathrm{hrs}$ after dosing in depleted and supplemented goats $(\mathrm{p}>0.05)$, respectively. The time when maximum ${ }^{75} \mathrm{Se}$ excretion occurred was different $(\mathrm{p}<0.05)$ in milk and in faeces.

During the first 20 hours urine was the primary route for ${ }^{75} \mathrm{Se}$ excretion, but later ${ }^{75} \mathrm{Se}$ excretion in faeces exceeded that in urine. On day two the proportion of ${ }^{75} \mathrm{Se}$ excreted in faeces was highest with an average of $88 \%$ for depleted and $80 \%$ for supplemented goats ( $p>0.05$ ). Subsequently there was a steady decrease in the proportion of ${ }^{75} \mathrm{Se}$ excreted in faeces and an increase in the proportion excreted in urine. In supplemented goats ${ }^{75} \mathrm{Se}$ excretion in urine exceeded that of faeces at day four after the dose, but in depleted goats faeces remained the primary route for ${ }^{75} \mathrm{Se}$ excretion over the 16 day follow-up period.

In depleted goats ${ }^{75} \mathrm{Se}$ excretion in milk resembled that in urine after $24 \mathrm{hrs}$, but in supplemented goats milk ${ }^{75} \mathrm{Se}$ was only onethird of that excreted in urine between 6 and 16 days after the dose (Figure 4). During the first $36 \mathrm{hrs}$ there was no difference in proportional excretion between depleted and supplemented goats. During the time interval between 36 hrs and 5 days proportionally more $(p<0.01)$ of ${ }^{75} \mathrm{Se}$ was excreted in urine in supplemented goats and less in faeces $(p<$ 0.05 ) than in depleted ones. After five days proportional excretion of ${ }^{75} \mathrm{Se}$ was lower in urine and higher in faeces in depleted goats $(p<0.05)$. A slightly higher proportion of ${ }^{75} \mathrm{Se}$ was excreted via milk in depleted goats than in supplemented ones ( $26.4 \%$ vs. $15.9 \%$, $\mathrm{p}=0.09$ ). Interaction between dietary selenium level and time was significant $(\mathrm{p}<0.001)$ only in faeces and in total excretion indicating more rapid excretion of selenium in selenium supplemented goats than in depleted ones. 

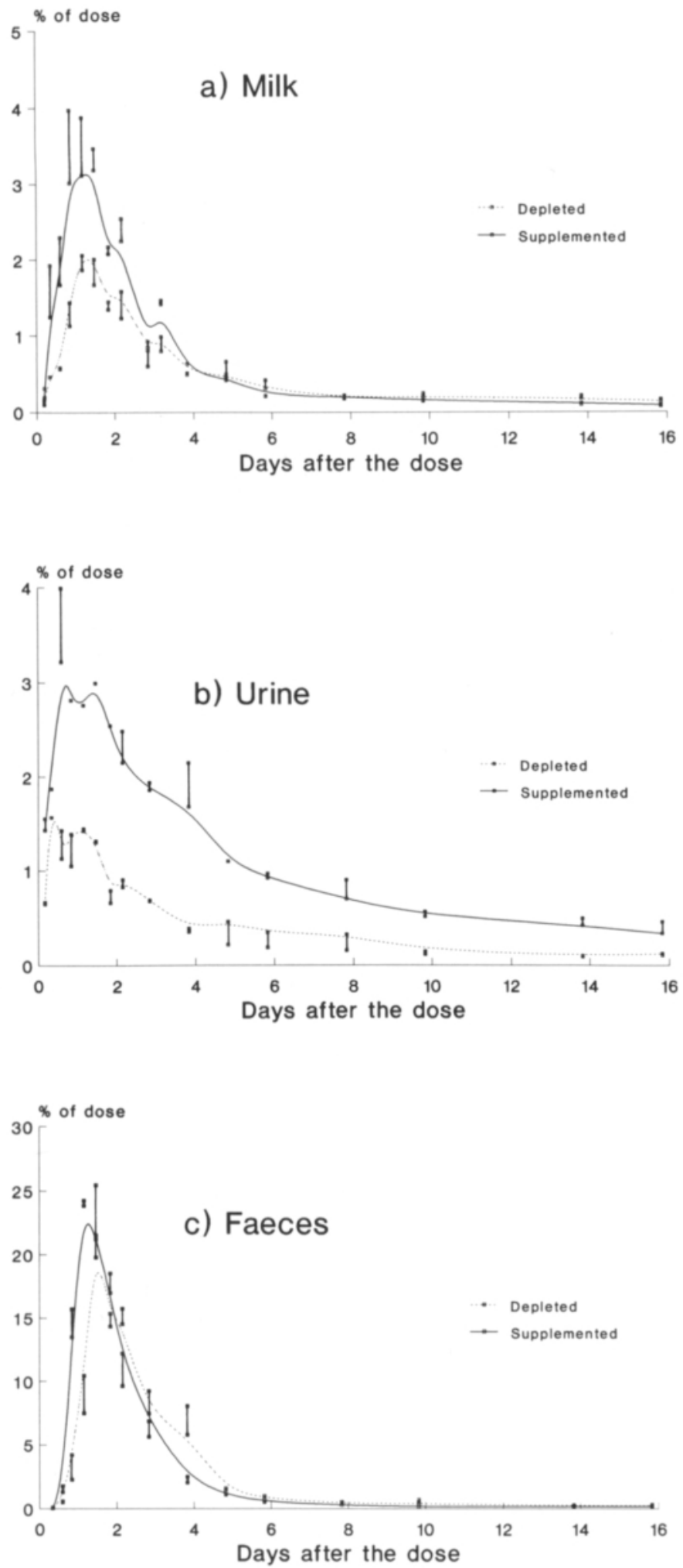

Figure 3. Excretion of ${ }^{75} \mathrm{Se}$ after oral dose a) in milk b) in urine c) in faeces in experiment $1,(n=2, \bar{x} \pm S E)$. 


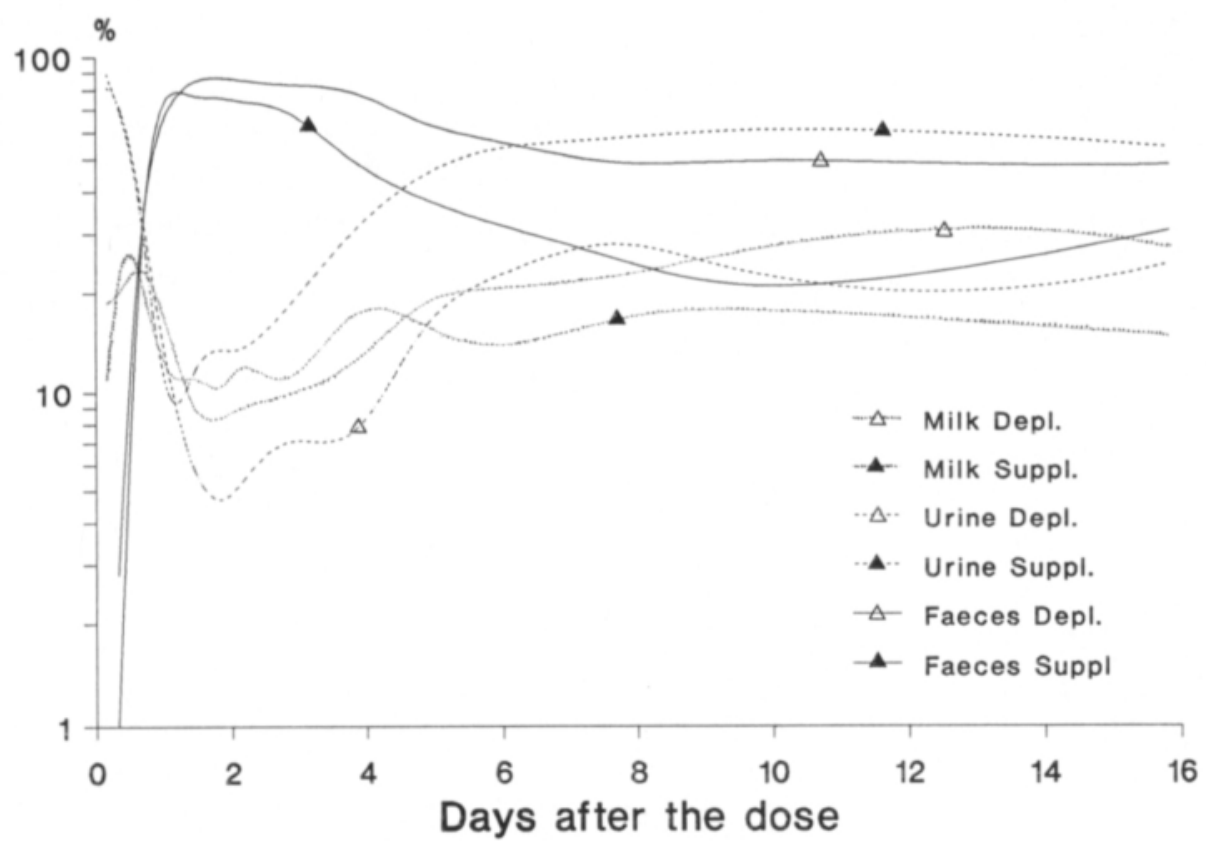

Figure 4. Proportional excretion of ${ }^{75} \mathrm{Se}$ after oral dose in experiment $1,(n=2)$.

\subsubsection{Rate constants}

There were no differences between the two selenium treatments in rate constants calculated based on ${ }^{75} \mathrm{Se}$ excreted in milk, urine or faeces (see Appendix 1). Only $k_{1}$-values based on total excretion of ${ }^{75} \mathrm{Se}$ differed between the selenium levels $(\mathrm{p}<0.05)$. Urine $\mathrm{k}_{1}$ values are rough estimates due to a great variation in the volume of urine voided. The only differences found were in $\mathrm{k}_{2}$-values between excretion paths $(\mathrm{p}<0.001)$ and in interaction between the path and selenium supplementation $(\mathrm{p}<0.05)$.

\subsubsection{3. ${ }^{75} \mathrm{Se}$ in plasma and erythrocytes}

Plasma ${ }^{75} \mathrm{Se}$ values reached their maximum two days after the dose. The maximum value for depleted goats was $7.9 \pm 0.6$ and for supplemented ones, $4.6 \pm 0.1 \%$ of dose $(p<$ 0.05 ). After the maximum values there was a steady decrease in plasma ${ }^{75} \mathrm{Se}$-activity, but the regression analysis of the slope revealed no difference between two selenium treatments (Figure 5).

Erythrocyte ${ }^{75}$ Se-activity tended to be slightly higher (1.0 vs. $0.5 \%$ of dose) in de- pleted goats than in supplemented ones. There was great variation in the time when erythrocyte ${ }^{75}$ Se-activity reached maximum. However, at 1.5 days after the dose erythrocyte ${ }^{75} \mathrm{Se}$ values were close to maximum and they remained at this level over the 16 day followup period.

\subsection{2. ${ }^{75}$ Se given intraruminally as sodium selenite}

\subsubsection{Excretion of ${ }^{75} \mathrm{Se}$}

During the 18 day follow-up period (phase II) after the intraruminal ${ }^{75} \mathrm{Se}$-dose total excretion was $56.7 \pm 3.2$ and $64.8 \pm 0.1 \%$ of the dose in depleted and supplemented goats, respectively. During the same time interval in depleted goats $4.0 \pm 0.7,10.2 \pm 2.9$ and $42.5 \pm$ $0.9 \%$ of the dose was excreted in milk, urine and faeces, respectively, and in selenium supplemented goats $4.3 \pm 0.6,22.1 \pm 2.2$ and $38.4 \pm 1.7 \%$, respectively. The difference between the selenium treatments was significant $(\mathrm{p}<0.05)$ only in urine.

In depleted goats there was no actual peak in ${ }^{75} \mathrm{Se}$ excretion in milk; ${ }^{75} \mathrm{Se}$ activity slowly 


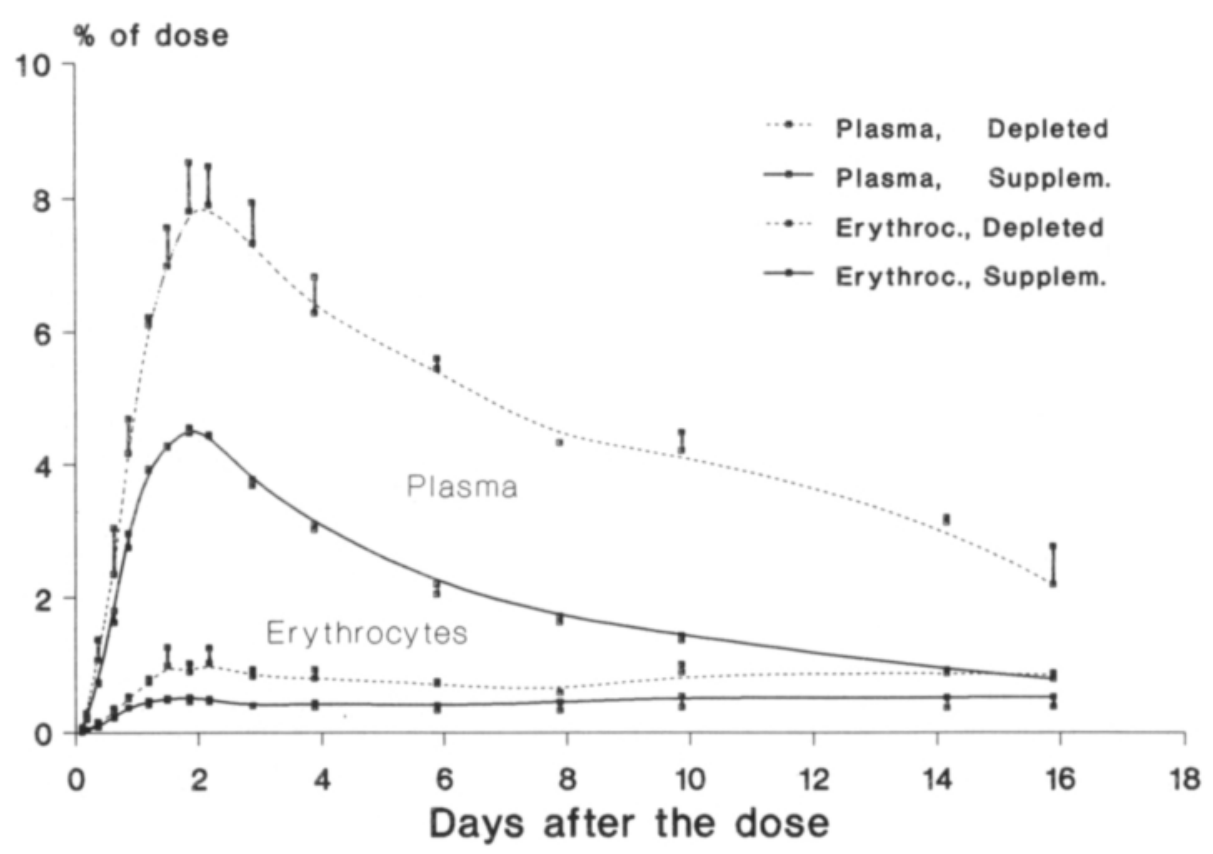

Figure 5. ${ }^{75} \mathrm{Se}$ in plasma and erythrocytes after oral dose in experiment $1,(\mathrm{n}=2, \overline{\mathrm{x}} \pm \mathrm{SE})$.

increased reaching its highest activity at $3.1 \mathrm{~d}$ post dosing. Maximal ${ }^{75} \mathrm{Se}$ excretion in milk differed between the two selenium treatments $(p<0.01$, Figure 6a). Depleted goats had only two components in their excretion curves. Also the maximum urinary excretion value in supplemented goats tended to be higher than in depleted ones $(p=0.07$, Figure $6 b) .{ }^{75} \mathrm{Se}$ excretion in faeces was similar in the two groups (Figure 6c). Interaction between the selenium level and time was significant in milk $(p<0.001)$ and urine $(p<0.05)$, but not in faeces or in total excretion rate $(p>0.05)$. Time after the dose had a significant effect $(\mathrm{p}<$ 0.001 ) in all cases. Interaction between the selenium level and path for excretion was significant $(\mathrm{p}<0.05)$, and there was a strong tendency for selenium level to affect excretion path $(p=0.07)$. Total mean retention time (TMRT) and half-life $\left(\mathrm{T}_{1 / 2}\right)$ based on ${ }^{75} \mathrm{Se}$ excreted in urine were different between the selenium levels $(p<0.05)$. Dietary level significantly affected the excretion paths $(\mathrm{p}<0.001)$. The interaction between the path and the selenium level significantly affected both TMRT and $\mathrm{T}_{1 / 2}(\mathrm{p}<0.01)$.
During the first $20 \mathrm{hrs}$ urine was the primary route for ${ }^{75} \mathrm{Se}$ excretion followed by milk. Thereafter ${ }^{75} \mathrm{Se}$ excreted in faeces exceeded that of urine and milk. The proportion of ${ }^{75} \mathrm{Se}$ excreted in faeces was highest at day two after the dose at $92 \%$ of total daily excretion for depleted and $78 \%$ for supplemented goats $(p>0.05)$. At the same time the proportion of ${ }^{75} \mathrm{Se}$ excreted in milk and urine reached their minimums. Thereafter a steady increase in proportion of ${ }^{75} \mathrm{Se}$ excreted in milk and urine resulted in the proportion of ${ }^{75} \mathrm{Se}$ excreted in the urine exceeding that in faeces at day five in supplemented goats and at day nine in depleted goats. The proportion of ${ }^{75} \mathrm{Se}$ excreted in milk exceeded that in faeces on day 11 in both depleted and supplemented goats (Figure 7). The proportion of ${ }^{75} \mathrm{Se}$ excreted in urine and faeces differed significantly in the two groups $(\mathrm{p}<0.05)$, but was similar in milk between groups. In milk the proportion of excreted ${ }^{75} \mathrm{Se}$ was greater $(\mathrm{p}<$ 0.05 ) during the time interval between 5 and 18 days than during the first five days. In urine the proportion was lowest $(\mathrm{p}<0.05)$ during the time interval between two and five days 

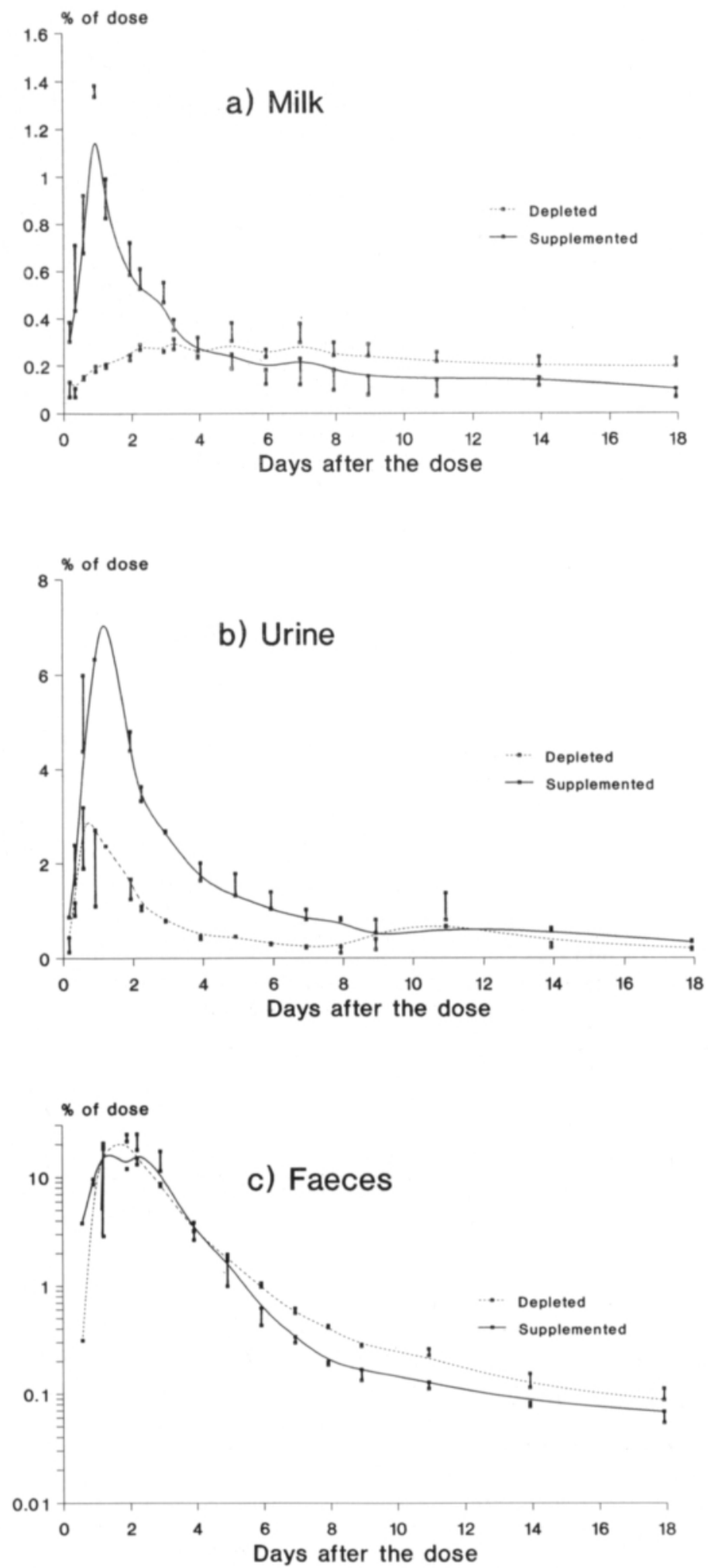

Figure 6. Excretion of ${ }^{75} \mathrm{Se}$ after I.R. dose a) in milk b) in urine c) in faeces in experiment $1,(n=2, \bar{x} \pm S E)$. 


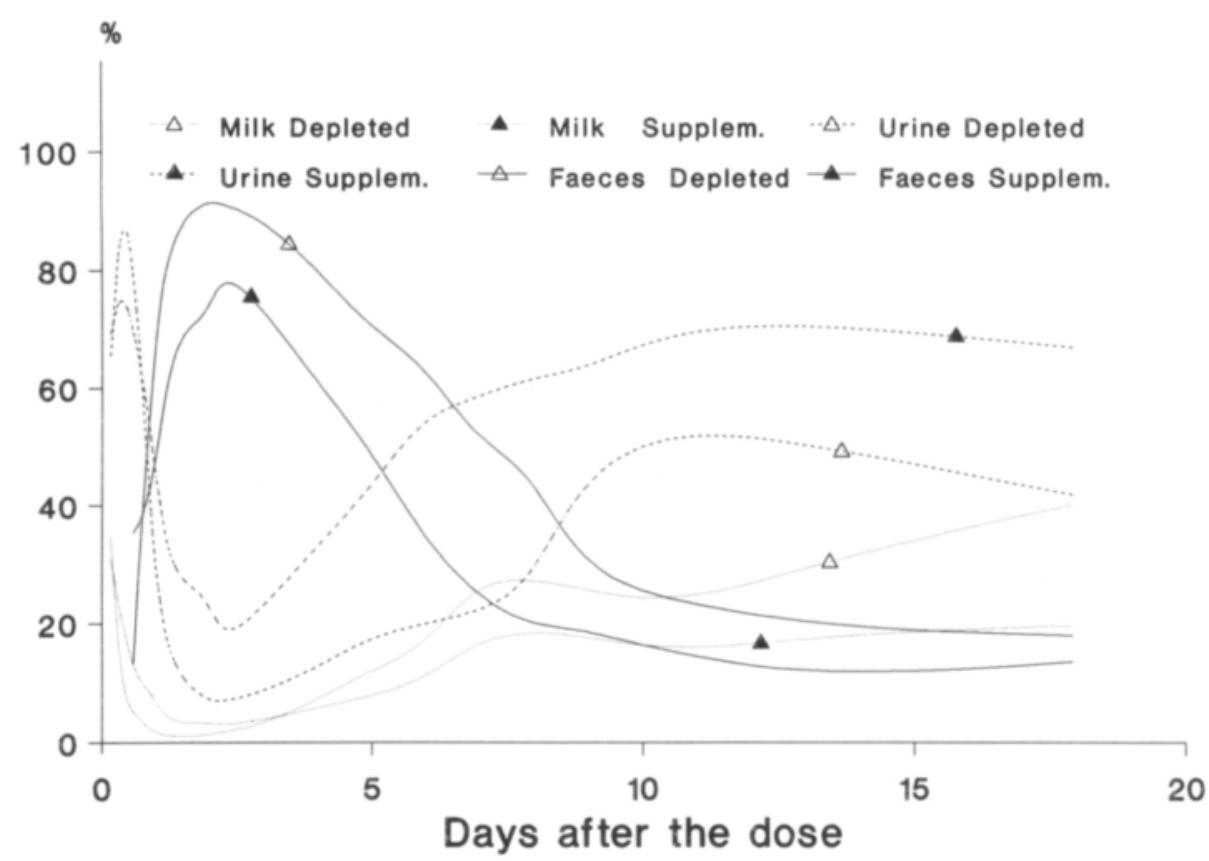

Figure 7. Proportional excretion of ${ }^{75} \mathrm{Se}$ after I.R. dose in experiment $1,(n=2)$.

after the dose, during which time the faecal proportion was highest $(\mathrm{p}<0.001)$.

\subsubsection{Rate constants}

Each of excretion curves consisted of three components, except the curve describing the ${ }^{75} \mathrm{Se}$ excretion in milk in depleted goats, which had only two components. There were no differences in rate constants either between the selenium levels or the excretion paths (Appendix 1). However, in $k_{3}$ the interaction between the selenium level and excretion path was significant $(\mathrm{p}<0.01)$.

\subsubsection{3. ${ }^{75} \mathrm{Se}$ in plasma and erythrocytes}

The maximum values of ${ }^{75} \mathrm{Se}$ activity in plasma were reached two days after the dose and they were higher in depleted goats than in supplemented ones $(13.9 \%$ vs. $7.5 \%$ of the dose, $\mathrm{p}<0.01$ ). Thereafter there was a steady decrease in plasma ${ }^{75} \mathrm{Se}$ values, although the slope of the regression was not affected by selenium level. However, at the end of 18 day follow-up period plasma ${ }^{75} \mathrm{Se}$ ac- tivities were higher $(\mathrm{p}<0.05)$ in depleted goats than in supplemented ones (Figure 8).

${ }^{75}$ Se-activity in the first samples of erythrocytes had a high proportion of background remaining from the first phase and they were thus omitted from the analysis. Maximum values in supplemented goats were reached at day two after the dose and thereafter values steadily decreased. In depleted goats, however, erythrocyte ${ }^{75} \mathrm{Se}$ values began to increase again four days after the dose. At day 14 the values exceeded those found at day two and the maximum values were reached at the end of the 18 day follow-up period. Regression analysis indicates that the slope of ${ }^{75} \mathrm{Se}$ activity in erythrocytes $(p<0.05)$ as well as ${ }^{75} \mathrm{Se}$ activity in erythrocytes at the end of the follow-up period $(\mathrm{p}<0.01)$ were different between the selenium treatments.

\subsection{3. ${ }^{75}$ Se given intravenously as selenomethionine}

\subsubsection{Excretion of ${ }^{75} \mathrm{Se}$}

During the 18 day follow-up period (phase 


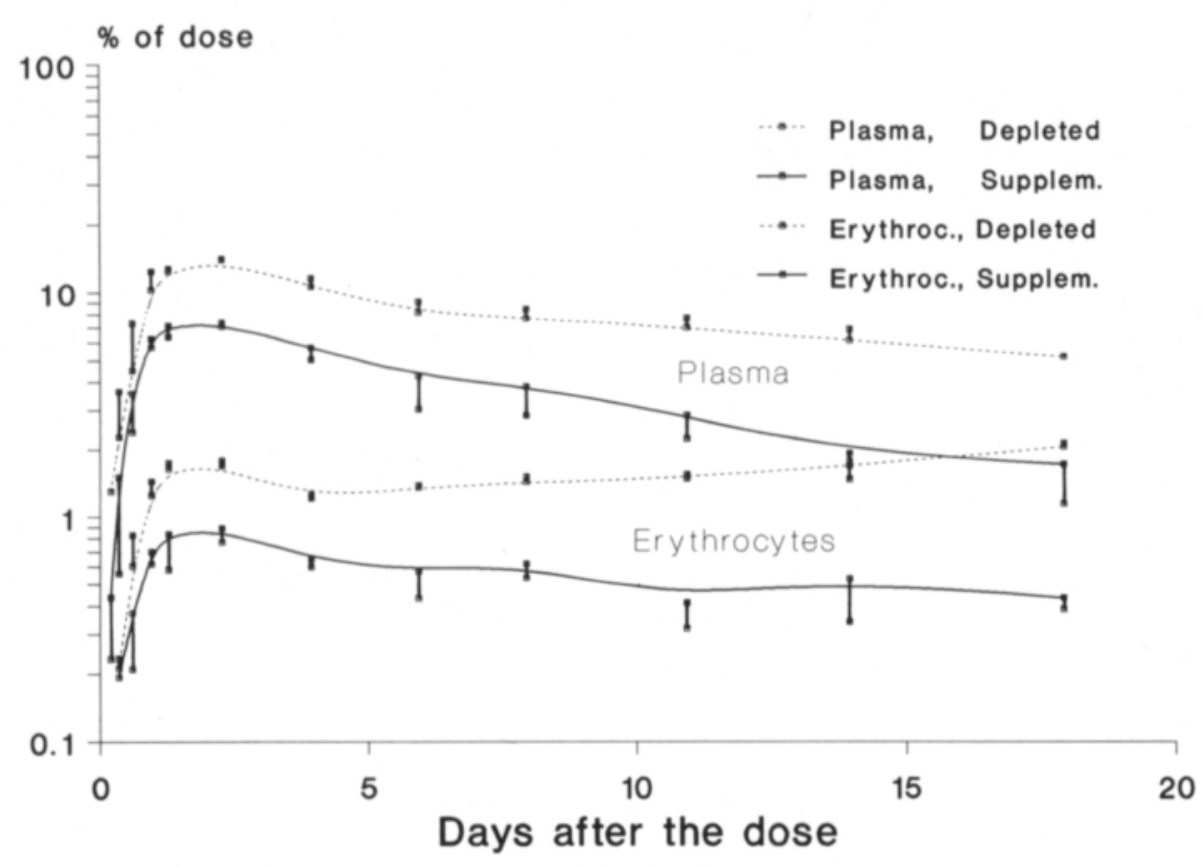

Figure 8. ${ }^{75} \mathrm{Se}$ in plasma and erythrocytes after I.R. dose in experiment $1,(\mathrm{n}=2, \overline{\mathrm{x}} \pm \mathrm{SE})$.

III) after the intravenous ${ }^{75} \mathrm{Se}$-selenomethionine dose total excretion was $43.5 \pm 4.2$ and $67.9 \pm 5.4 \%$ of the dose in depleted and supplemented goats, respectively. During the same time interval $33.2 \pm 3.8,4.8 \pm 0.4$ and $5.4 \pm 0.01$, and $35.8 \pm 1.8,25.7 \pm 7.6$ and $6.3 \pm 0.4 \%$ of the dose was excreted in milk, urine and faeces in depleted and supplemented goats, respectively (Figure 9). The differences between the selenium treatment groups were non-significant even though there was a trend $(p=0.09)$ for different excretion rates in urinary ${ }^{75} \mathrm{Se}$ when corrected to $100 \%$ excretion.

Excretion of ${ }^{75} \mathrm{Se}$ in urine and milk was a very rapid process and maximum excretion in urine occurred in the first samples $1.5 \mathrm{hrs}$ post dosing. In milk, excretion ( $\%$ of dose $/ \mathrm{h})$ was equal during the time intervals $0-1.5 \mathrm{hrs}$ and $1.5-3 \mathrm{hrs}$, indicating that maximum excretion probably occurs before $1.5 \mathrm{hrs}$ post dosing. In faeces peak excretion occurred at $20 \mathrm{hrs}$ post dosing, but in spite of relative frequent sampling, it was not possible to determinate transit time. At the end of the follow-up pe- riod total ${ }^{75}$ Se excretion $(\mathrm{p}<0.05)$ and excretion in urine $(p<0.01)$ were higher in supplemented than in depleted goats.

In depleted goats milk was the primary route for ${ }^{75} \mathrm{Se}$ excretion with the percentage exceeding $50 \%$ throughout the 18 day followup period. In supplemented goats most of ${ }^{75} \mathrm{Se}$ was excreted via milk during the first two days, but then excretion in urine was comparable to that in milk and after seven days it exceeded ${ }^{75} \mathrm{Se}$ excretion in milk. Urinary excretion of ${ }^{75} \mathrm{Se}$ was close to $60 \%$ at day 18 post dosing. In depleted goats excretion in urine played only a minor role with an overall percentage of less than $20 \%$. In depleted goats proportion of ${ }^{75} \mathrm{Se}$ excreted in faeces exceeded that of urine at eight hours post dosing and remained above that of urine over the follow-up period. Proportion of ${ }^{75} \mathrm{Se}$ excreted in faeces plateaued at $25 \%$ five days post dosing. In supplemented goats the proportion of ${ }^{75} \mathrm{Se}$ excreted in faeces was highest at day seven post dosing and thereafter slightly decreased and plateaued at $13 \%$ of excretion. 

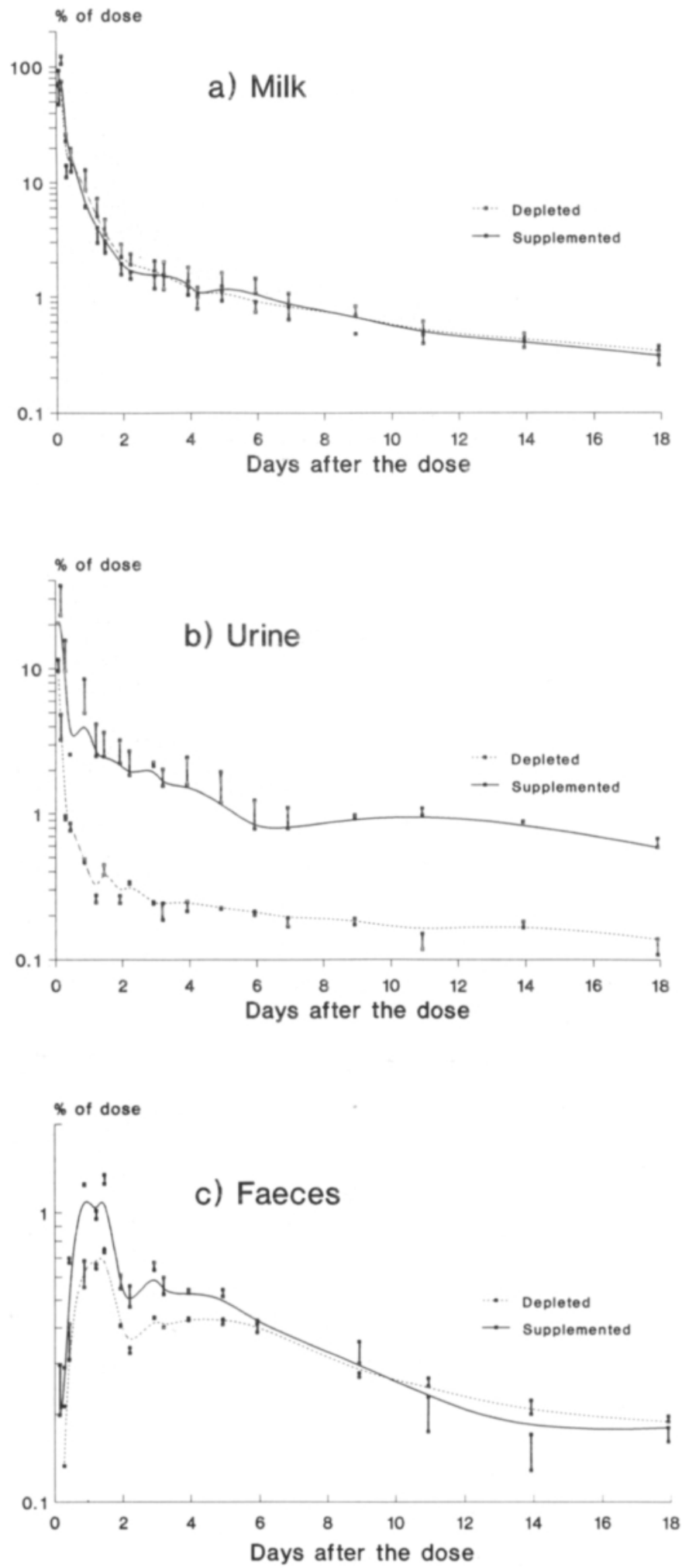

Figure 9. Excretion of ${ }^{75}$ after I.V. dose a) in milk b) in urine c) in faeces in experiment $1,(\mathrm{n}=2, \overline{\mathrm{x}} \pm \mathrm{SE})$. 


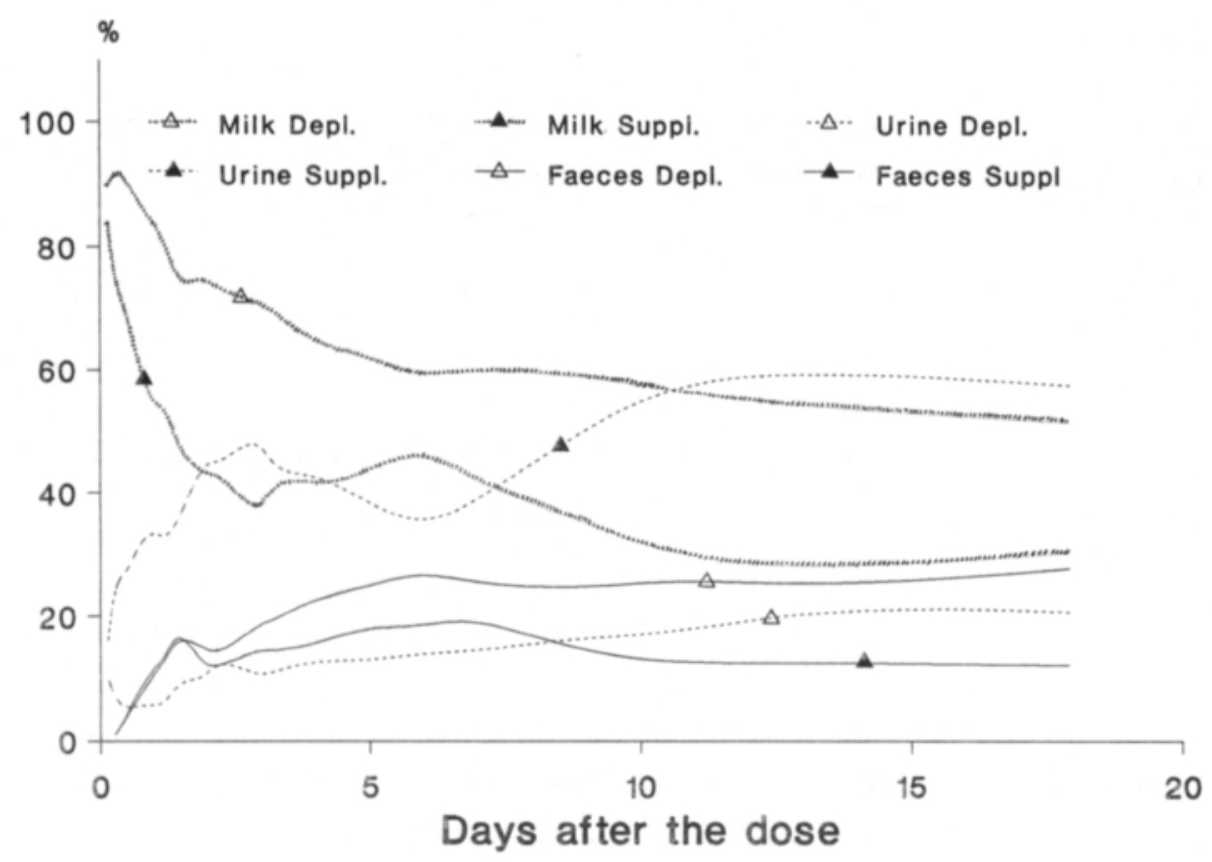

Figure 10. Proportional excretion of ${ }^{75} \mathrm{Se}$ after I.V. dose in experiment $1,(n=2)$.

At the end of the follow-up period differences in proportional excretion between the selenium treatments were significant $(p<0.05)$ in milk, urine and faeces (Figure 10).

\subsubsection{Rate constants}

Each of excretion curves consisted of three components, except curves based on faecal ${ }^{75} \mathrm{Se}$ excretion, which had only two components. Differences between the selenium levels were insignificant, but differences between the excretion paths were significant $(\mathrm{p}<0.05)$ in $k_{1}$ and $k_{3}$, and also in $T_{1 / 2}$.

\subsubsection{3. ${ }^{75} \mathrm{Se}$ in plasma and erythrocytes}

${ }^{75} \mathrm{Se}$ retained in plasma was reduced within 10 minutes to $11.4 \%$ and $8.6 \%$ of the dose in depleted and supplemented goats, respectively. Diminution of ${ }^{75} \mathrm{Se}$ activity in plasma continued until 30 minutes after the dose whereupon ${ }^{75} \mathrm{Se}$ levels rose for four hours, when maximum ${ }^{75} \mathrm{Se}$ activities in plasma were reached both in depleted and supplemented goats ( 17.5 vs. $13.0 \%$ of the dose, $p=0.08)$. Thereafter ${ }^{75} \mathrm{Se}$ activity decreased until the end of follow-up period, but there were no differences $(p<0.05)$ between either the final selenium values or in the slopes of the regression (Figure 11).

${ }^{75} \mathrm{Se}$ activity of erythrocytes showed two minimums at the time points of 30 minutes, and at day two in depleted and at day four in supplemented goats. ${ }^{75} \mathrm{Se}$ activity in erythrocytes continued to increase towards the end of follow-up period when depleted goats had maximum activity. In supplemented goats the maximum value reached at two hours post dosing was not exceeded during the follow-up period. The difference between the selenium treatment groups was insignificant even though erythrocyte ${ }^{75}$ Se activity in depleted goats was on the average twice that of supplemented goats.

\subsection{Experiment 2}

\subsection{1. ${ }^{75}$ Se given orally and intraruminally}

\subsubsection{Excretion of ${ }^{75} \mathrm{Se}$}

The intraruminal dose of ${ }^{75} \mathrm{Se}$-selenite failed in one of the goats, thus results from 


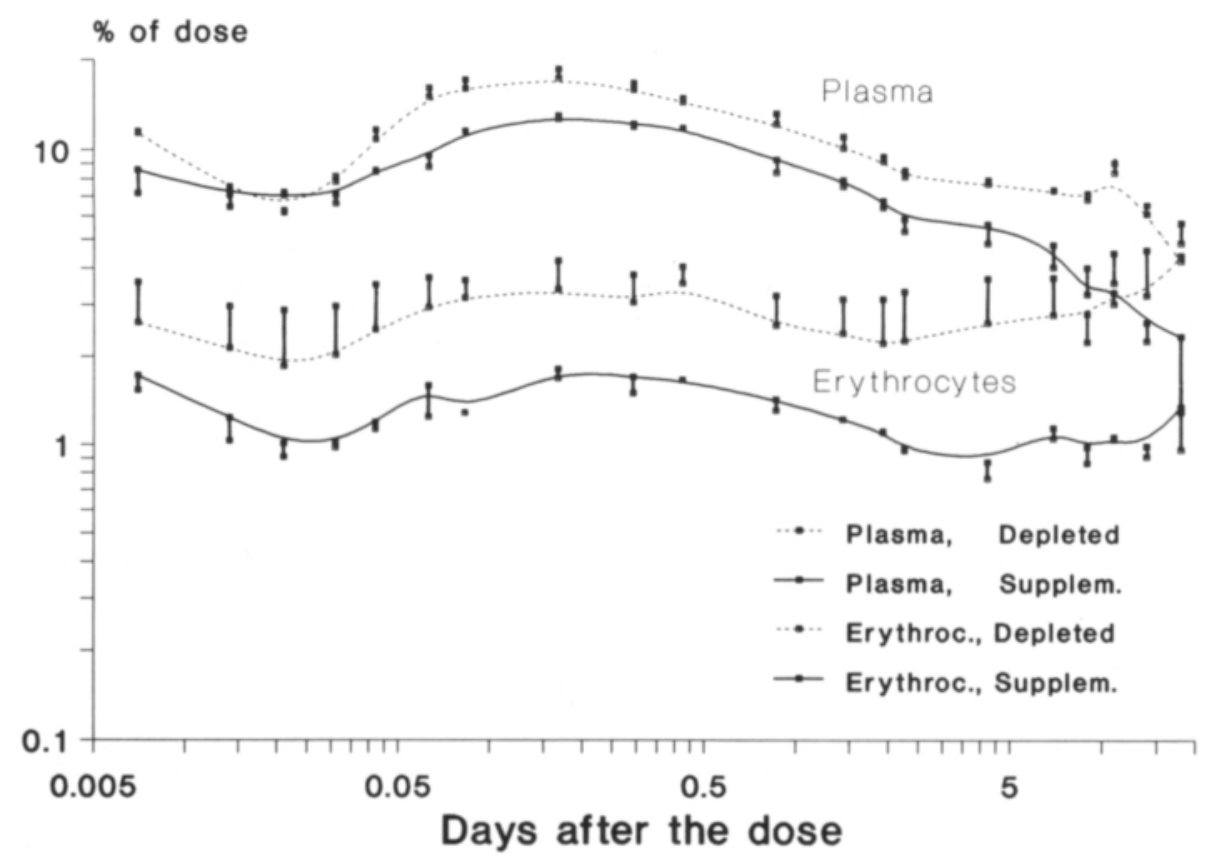

Figure 11. ${ }^{75} \mathrm{Se}$ in plasma and erythrocytes after I.V. dose a) in milk b) in urine c) in faeces in experiment $1,(\mathrm{n}=2, \overline{\mathrm{x}} \pm \mathrm{SE})$.

this animal were excluded from further analysis. Therefore no significances between the selenium sources are given. The other goat which was dosed intraruminally with inorganic ${ }^{75} \mathrm{Se}$ (IO) excreted 2.0, 21.3 and $68.8 \%$ of the dose, and the goats given orally ${ }^{75} \mathrm{Se}$ labeled grass (OR) excreted $7.9 \pm 0.76,15.5 \pm$ 0.2 and $59.8 \pm 9.0 \%$ of the dose in milk, urine and faeces, respectively, during the 28 day follow-up period. Total excretion was thus 92.1 and $70.0 \pm 4.8 \%$ of the dose in IO goat and OR goats, respectively.

Maximum excretion tended to occur later in the IO goat than in OR goats (13.7 vs. 9.8 hrs) even though transit time (TT) was shorter for IO (1.9 vs. $2.2 \mathrm{hrs})$. The maximum excretion value in milk for the IO goat was $0.7 \%$ and for the OR goats $3.6 \%$ of the dose (Figure 12a). One of the OR goats voided urine very infrequently and thus it was impossible to determine values for compartments having a fast turnover rate. Maximal ${ }^{75} \mathrm{Se}$ excretion in urine occurred at 16.1 and $23.5 \mathrm{hrs}$, and TT was $7.7 \mathrm{hrs}$ and $7.7 \mathrm{hrs}$ after dosing in $\mathrm{IO}$ and OR goats, respectively (Figure $12 \mathrm{~b}$ ). In fae- ces maximum excretion occurred at $29.8 \mathrm{hrs}$ for the IO goat and at $32.4 \mathrm{hrs}$ for OR goats (Figure 12c).

During the first $20 \mathrm{hrs}$ post-dosing urine was the primary route for ${ }^{75} \mathrm{Se}$ excretion in the IO goat, while in OR goats milk was the primary mode of excretion during the same time interval. Thereafter excretion in faeces contributed the bulk of ${ }^{75} \mathrm{Se}$ excretion until six days post dosing in both groups. Two weeks after dosing proportional excretion tended to plateau with only a slight decrease in the proportion of ${ }^{75} \mathrm{Se}$ excreted in urine. The levels of the plateau were in the IO goat 10 , 55 and $35 \%$, and in OR goats were 20,50 and $30 \%$ of total excretion in milk, urine and faeces, respectively (Figure 13).

\subsubsection{Rate constants}

There were no differences in rate constants either between the selenium sources or in interactions between the selenium source and the excretion path. However, there were differences in $k_{4}$, TMRT and $T_{1 / 2}$ values between the excretion paths (Appendix 1). 

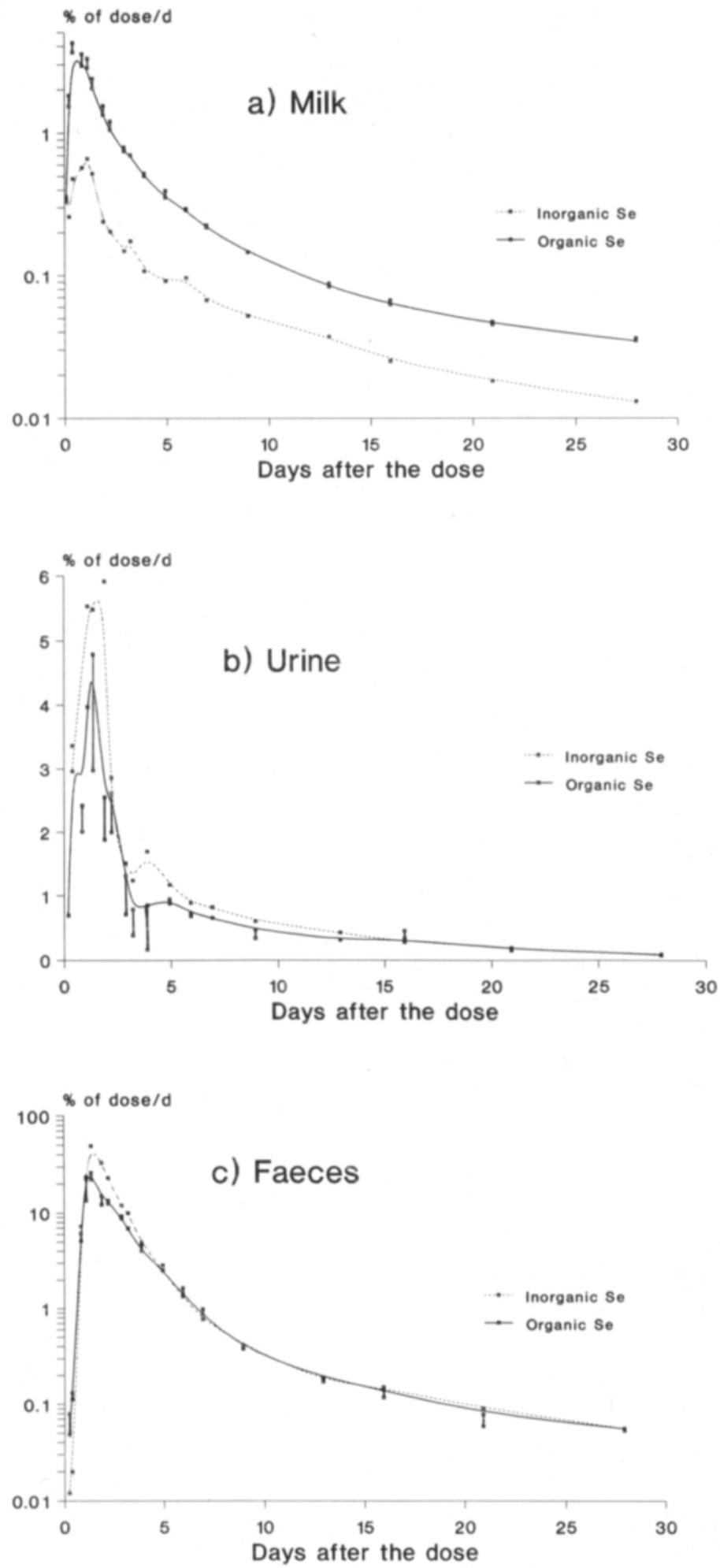

Figure 12. Excretion of ${ }^{75} \mathrm{Se}$ after oral and I.R. dose a) in milk b) in urine c) in faeces in experiment 2 , (for organic $\operatorname{Se} n=2$, $\overline{\mathrm{x}} \pm \mathrm{SE}$, for inorganic Se $\mathrm{n}=1$ ). 


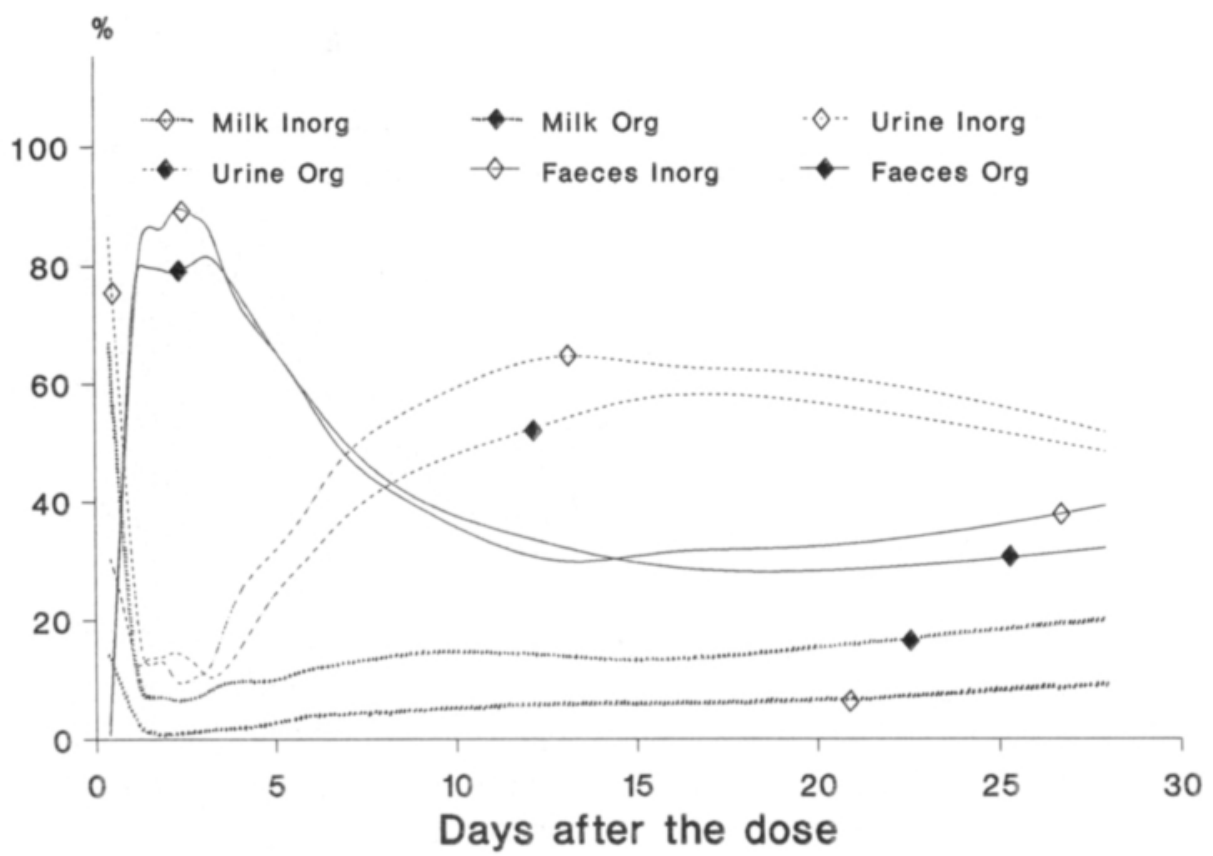

Figure 13. Proportional excretion of ${ }^{75} \mathrm{Se}$ after oral and I.R. dose in experiment 2, (for organic Se $\mathrm{n}=2$, for inorganic Se $\mathrm{n}=1$ ).

\subsubsection{3. ${ }^{75} \mathrm{Se}$ in plasma, erythrocytes and hair}

For IO and OR goats the transit time of ${ }^{75} \mathrm{Se}$ to plasma was 1.2 and $1.4 \mathrm{hrs}$, whereupon plasma ${ }^{75} \mathrm{Se}$ activity increased rapidly until 10 hrs. Maximum activity was reached at $22 \mathrm{hrs}$ post dosing with maximum values of $5.2 \%$ and $3.8 \%$ of the dose, respectively. The regression coefficients of the slope showed no effect on the plasma ${ }^{75} \mathrm{Se}$ activity curves due to selenium source (Figure 14).

Erythrocyte ${ }^{75} \mathrm{Se}$ activity increased rapidly during the first $10 \mathrm{hrs}$ after dosing, but it was not possible to calculate transit time because of the steady increase in erythrocyte ${ }^{75} \mathrm{Se}$ activity towards the end of the 28 day followup period. The regression slopes during the first $10 \mathrm{hrs}$ as well as the final ${ }^{75} \mathrm{Se}$ values in erythrocytes appeared to be different. By day 21 erythrocyte ${ }^{75} \mathrm{Se}$ activity exceeded that of plasma in both groups.

${ }^{75} \mathrm{Se}$-activity increased slowly in hair. After 13 days $0.15 \%$ and after 28 days $0.7 \%$ of the dose was calculated to be in hair both in IO goat and OR goats.

\subsection{2. ${ }^{75}$ Se given intravenously as sodium selenite and selenomethionine}

\subsubsection{Excretion of ${ }^{75} \mathrm{Se}$}

After the intravenous dose of ${ }^{75} \mathrm{Se}$-selenite or ${ }^{75} \mathrm{Se}$-selenomethionine the goats excreted $3.6 \pm 0.6,64.2 \pm 2.2$ and $15.3 \pm 0.3 \%$, and $32.1 \pm 0.4,35.0 \pm 3.8$ and $15.8 \pm 0.4 \%$ of the dose in milk, urine and faeces, respectively, during the 28 day follow-up period. Total excretion was thus $83.2 \pm 1.8 \%$ and $83.0 \pm$ $3.8 \%$ for IO and OR goats, respectively. Selenium source affected the proportion of ${ }^{75} \mathrm{Se}$ in milk $(\mathrm{p}<0.001)$ and urine $(\mathrm{p}<0.05)$.

${ }^{75} \mathrm{Se}$ excretion after the intravenous dose was very rapid and the highest radioactivity $(\mathrm{cpm} / \mathrm{g}$ ) was measured in milk samples taken at $1 \mathrm{~h}$ and in urine at $6 \mathrm{hrs}$ (Figures 15a and b). In faeces maximum excretion occurred at $17.0 \pm 0.7$ and $14.2 \pm 1.9 \mathrm{hrs}(\mathrm{p}>0.05)$ in IO and OR goats, respectively, with a similar type of excretion in both groups (Figure 15c). Regression analysis showed that ${ }^{75} \mathrm{Se}$ in milk declined more rapidly in OR goats while ${ }^{75} \mathrm{Se}$ 


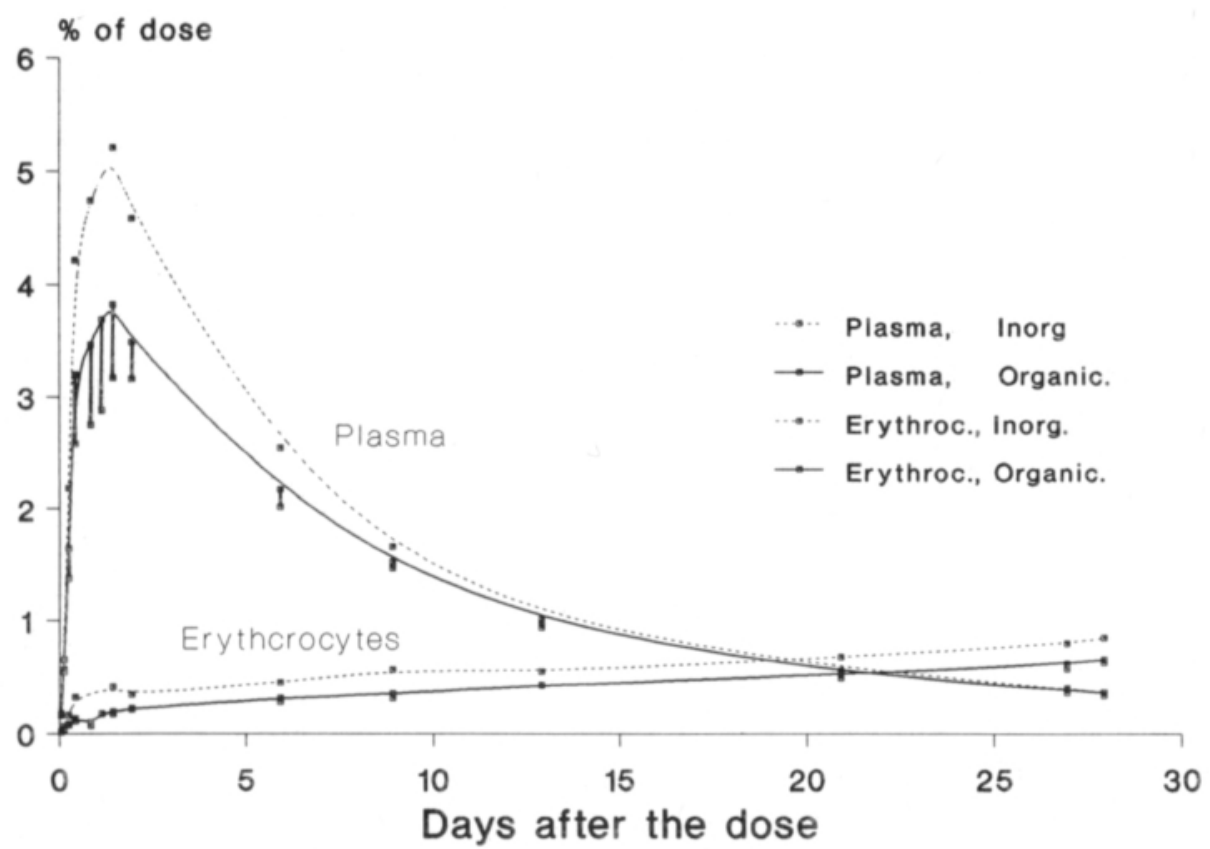

Figure 14. ${ }^{75} \mathrm{Se}$ in plasma and erythrocytes after oral and I.R. dose in experiment 2, (for organic Se $n=2, \bar{x} \pm S E$, for inorganic Se $n=1$ ).

in urine declined more slowly during the first $35 \mathrm{hrs}(\mathrm{p}<0.01)$. The difference between the final values due to selenium source was significant only in milk $(\mathrm{p}<0.05)$. Interaction between the selenium source and time was significant both in milk, urine $(\mathrm{p}<0.001)$, and faeces $(\mathrm{p}<0.05)$.

Urine was the primary route for ${ }^{75} \mathrm{Se}$ excretion after the I.V. dose in IO goats throughout the experiment and in OR goats later than $6 \mathrm{hrs}$ after dosing. In OR goats the excretion of ${ }^{75} \mathrm{Se}$ in milk contributed $70 \%$ of total excretion during the first 6 hrs, but thereafter it was exceeded by excretion in urine. The proportion of ${ }^{75} \mathrm{Se}$ excreted in milk tended to plateau at $6 \%$ and $22 \%(\mathrm{p}<0.05)$, and in urine at $71 \%$ and $55 \%$ of total excretion in IO and OR goats, respectively. The proportion of ${ }^{75} \mathrm{Se}$ excreted in faeces increased rapidly and reached $30 \%$ of total excretion at 33 hrs post dosing, thereafter declining slightly towards a plateau at $23 \%$ of the total excretion (Figure 16). Differences between the selenium sources in milk and urine $(\mathrm{p}<0.05)$, and the effect of time on milk $(\mathrm{p}<0.05)$ and faeces $(p<0.001)$ as well as the interaction between the selenium source and time in milk $(\mathrm{p}<0.01)$ were significant.

\subsubsection{Rate constants}

Due to rapid excretion of ${ }^{75} \mathrm{Se}$ in milk and urine all rate constants could only be determined for faecal excretion. The goats voided urine infrequently and thus only two of rate constants were determined in urine $\left(\mathrm{k}_{2}\right.$ and $\mathrm{k}_{4}$ ). In milk the highest activities were counted in the first samples and in spite of a one hour sampling interval, the fastest rate constant was incalculable. The turnover time for component $k_{1}$ was $4.7 \mathrm{hrs}$ for IO goats and $2.4 \mathrm{hrs}$ for OR goats $(p>0.05)$. A total of four rate constants were determined for milk (Appendix 1). Selenium source had a significant $(p<0.05)$ effect on $k_{2}$ and $k_{4}$.

\subsubsection{3. ${ }^{75} \mathrm{Se}$ in plasma, erythrocytes and hair}

More than $80 \%$ of the dose was recovered in plasma one minute post dosing. Thereafter 

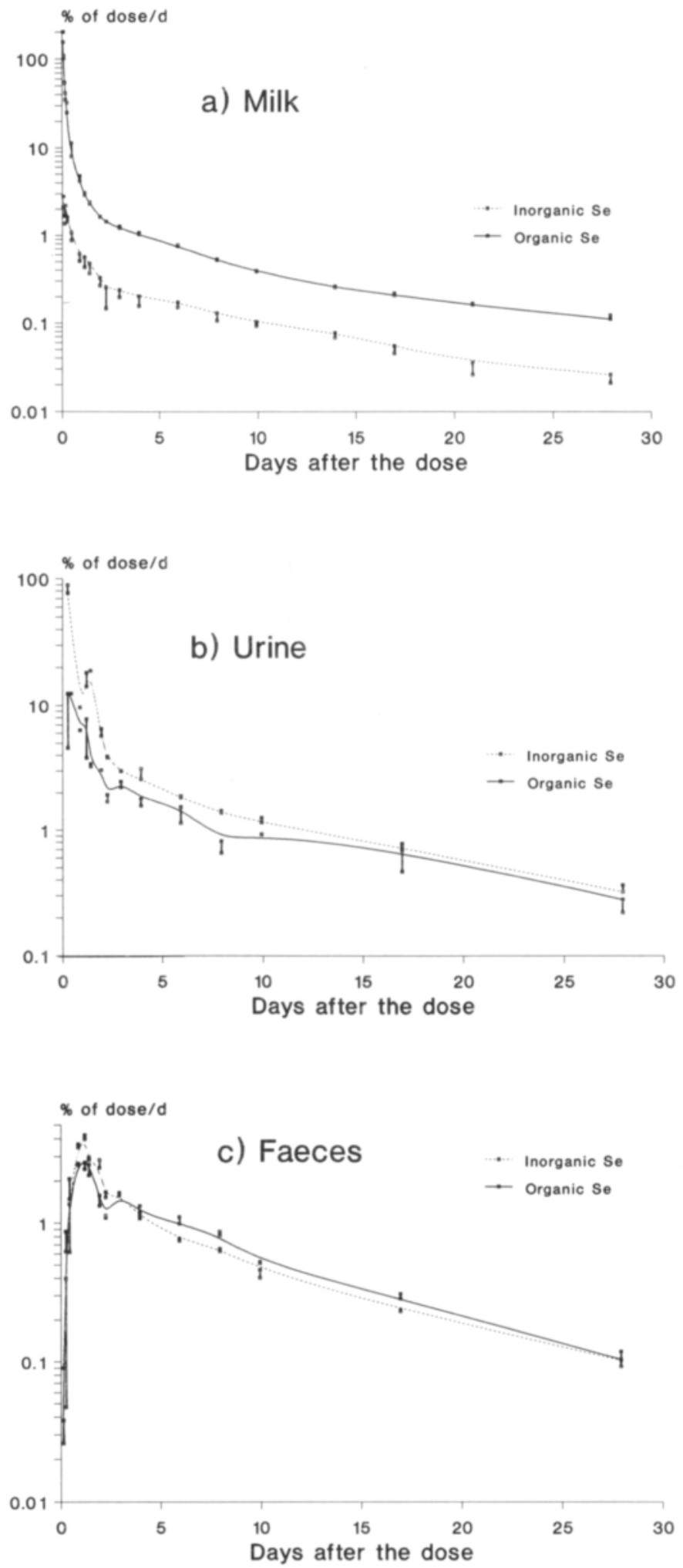

Figure 15. Excretion of ${ }^{75} \mathrm{Se}$ after I.V. dose a) in milk b) in urine c) in faeces in experiment $2,(n=2, \bar{x} \pm S E)$. 


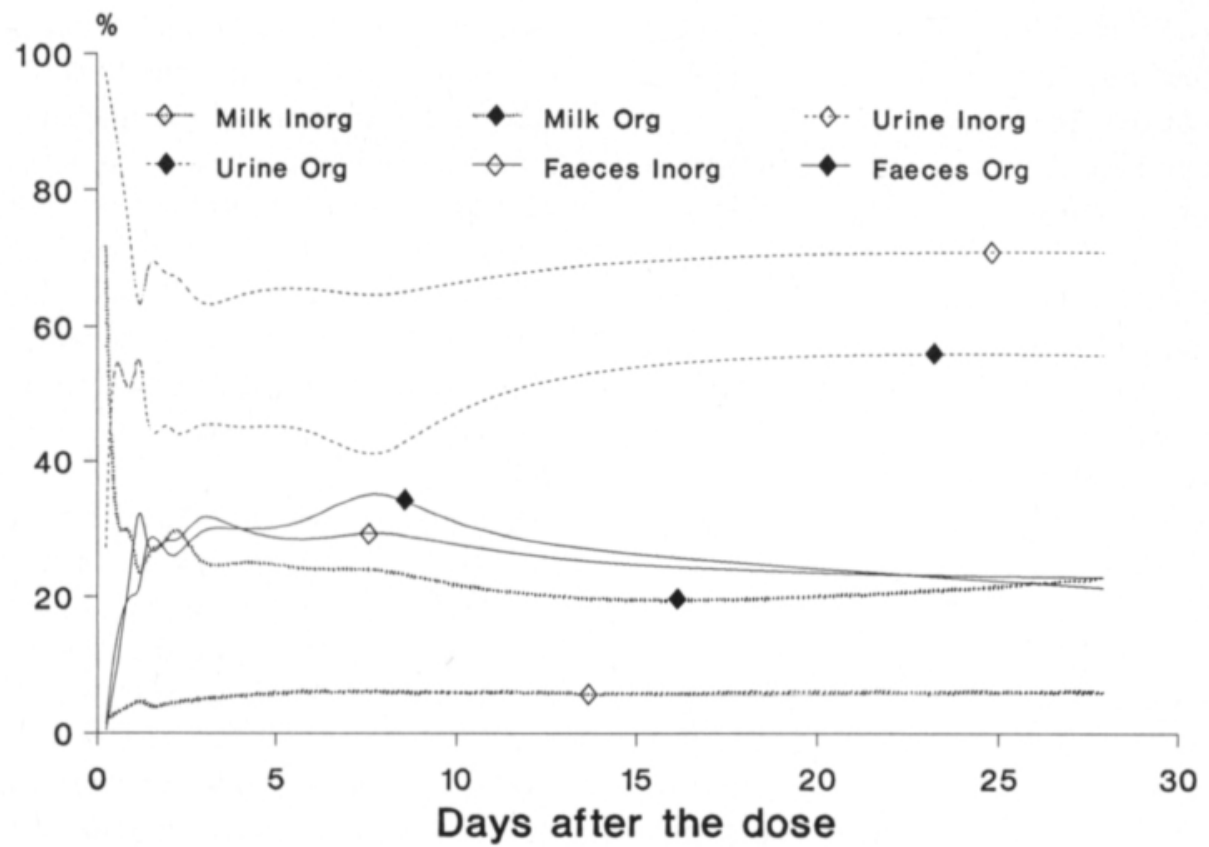

Figure 16. Proportional excretion of ${ }^{75} \mathrm{Se}$ after I.V. dose in experiment $2,(n=2)$.

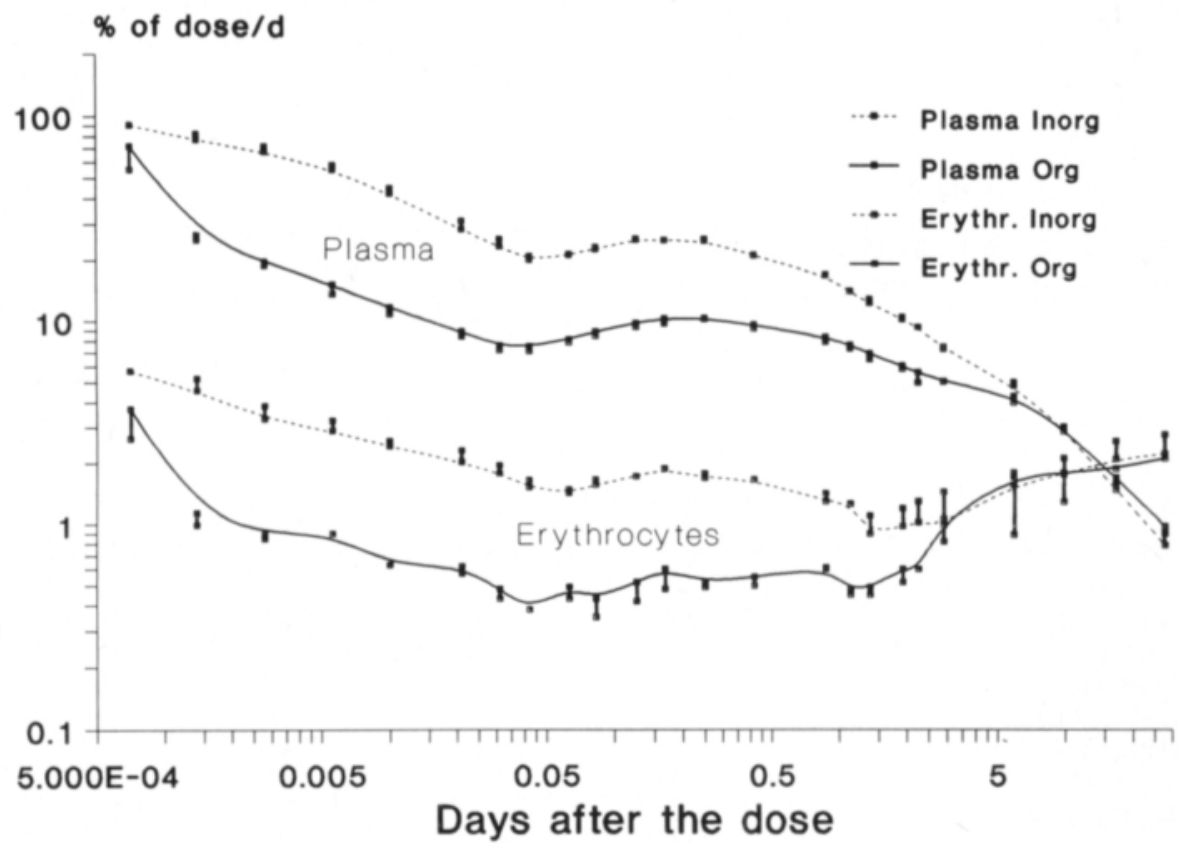

Figure 17. ${ }^{75} \mathrm{Se}$ in plasma and erythrocytes after I.V. dose in experiment $2,(\mathrm{n}=2, \overline{\mathrm{x}} \pm \mathrm{SE})$.

${ }^{75}$ Se activity in plasma decreased rapidly in OR goats, but more slowly in IO goats $(\mathrm{p}<$ 0.01 ). At one hour post dosing the ${ }^{75} \mathrm{Se}$ activity began to rise again until $4 \mathrm{hrs} .{ }^{75} \mathrm{Se}$ ac- tivity in plasma of IO goats was higher until 10 days whereupon it was exceeded by OR goats. The slope of the linear regression was steeper $(\mathrm{p}<0.05)$ in IO goats than in OR goats 
after 3 days post dosing. There was, however, no effect due to selenium source on final values at day 28 (Figure 17).

At one minute post dosing ${ }^{75} \mathrm{Se}$ activity in erythrocytes was in IO goats $5.7 \%$ and in OR goats $3.7 \%$ of the dose $(p>0.05)$. Thereafter ${ }^{75} \mathrm{Se}$ activity in erythrocytes decreased until one hour and then increased slightly and exceeded $2 \%$ of the dose in both groups at 28 days post dosing. More ${ }^{75} \mathrm{Se}$ was retained in erythrocytes in IO than in OR goats during the time interval from two minutes to $27 \mathrm{hrs}(\mathrm{p}<0.05)$. The proportion of ${ }^{75} \mathrm{Se}$ in erythrocytes exceeded that of plasma on day 14.

${ }^{75} \mathrm{Se}$ was retained more efficiently in hair when dosed as selenomethionine than as selenite. At 7 days post dosing the difference between the IO and OR goats was not great ( $0.4 \%$ vs. $0.6 \%$ of dose), but 28 days after dosing $0.6 \pm 0.03$ and $2.0 \pm 0.14 \%$ of dose $(\mathrm{p}<0.01)$ was calculated to be in hair in IO and OR goats, respectively.

\subsection{Experiment 3}

\subsubsection{Blood parameters}

Average plasma parameters, blood hemoglobin and hematocrit values in each group during the selenium supplementation periods (periods II - V) are given in the Table 4. Most of the values are similar among groups, but plasma glucose and plasma $\mathrm{Ca}$ level were higher $(\mathrm{p}<0.01)$ in the groups given organic Se than in the groups given no Se supplementation or supplemented with inorganic Se. Plasma ASAT and CK activities, which indicate cell damage in muscles and liver, were lower in the groups given organic $\mathrm{Se}(\mathrm{p}<$ $0.01)$.

Alpha-tocopherol was the only plasma tocopherol which was within the detection limit. Alpha-tocopherol content in the beginning of the experiment was $9.7,9.8,9.0$ and $8.5 \mathrm{mg} / \mathrm{l}$, and at day 259 was $4.3,4.1,5.1$ and $5.4 \mathrm{mg} / 1$ in the groups $1,2,3$ and 4 , respectively. The difference in the $\alpha$-tocopherol level between sampling times reflects seasonal differences, since the first sample was taken in September and the latter one in May. Plasma $\alpha$-tocopherol content tended to be positively correlated to plasma and whole blood selenium content as well as to GSH-Px content in plasma and whole blood.

\subsubsection{Plasma selenium}

Plasma selenium concentration was signifi-

Table 4. Plasma parameters, blood hemoglobin and hematocrit during periods $\mathrm{II}-\mathrm{V}$ in cows fed various Se diets (for group explanation see Table 1, p. 29).

\begin{tabular}{|c|c|c|c|c|c|}
\hline & \multicolumn{5}{|c|}{ Group } \\
\hline & 1 & 2 & 3 & 4 & \\
\hline \multicolumn{6}{|l|}{ Plasma } \\
\hline$-\mathrm{Ca}(\mathrm{mmol} / \mathrm{l})$ & $2.36^{\mathrm{a}}$ & $2.40^{\mathrm{ab}}$ & $2.50^{\mathrm{b}}$ & $2.45^{\mathrm{ab}}$ & \\
\hline$-\mathrm{P}(\mathrm{mmol} / \mathrm{l})$ & 1.62 & 1.69 & 1.64 & 1.63 & ns. \\
\hline$-\mathrm{Mg}(\mathrm{mmol} / \mathrm{l})$ & 0.94 & 0.98 & 0.97 & 0.93 & ns. \\
\hline - glucose $(\mathrm{mmol} / \mathrm{l})$ & $3.53^{\mathrm{a}}$ & $3.52^{\mathrm{a}}$ & $3.86^{b}$ & $3.83^{\mathrm{b}}$ & \\
\hline - cholesterol $(\mathrm{mmol} / \mathrm{l})$ & 5.21 & 5.55 & 5.41 & 5.33 & ns. \\
\hline - urea $(\mathrm{mmol} / \mathrm{l})$ & 3.55 & 4.01 & 4.06 & 4.03 & ns. \\
\hline - total protein $(\mathrm{g} / \mathrm{l})$ & 73.9 & 72.3 & 73.9 & 74.8 & ns. \\
\hline- albumin $(\mathrm{g} / \mathrm{l})$ & 38.4 & 39.8 & 39.4 & 38.9 & ns. \\
\hline - ASAT (IU/I) & $52.8^{\mathrm{ab}}$ & $63.1^{\mathrm{b}}$ & $49.0^{\mathrm{a}}$ & $48.6^{\mathrm{a}}$ & \\
\hline$-\gamma$-GT (IU/1) & 19.0 & 20.6 & 20.3 & 18.5 & ns. \\
\hline - CK (IU/l) & $79.0^{\mathrm{a}}$ & $113.1^{\mathrm{b}}$ & $69.6^{a}$ & $68.8^{\mathrm{a}}$ & \\
\hline \multicolumn{6}{|l|}{ Whole Blood } \\
\hline - hemoglobin $(\mathrm{g} / \mathrm{l})$ & 121.6 & 121.1 & 116.2 & 119.6 & ns. \\
\hline - hematocrit $(\%)$ & 36.1 & 35.8 & 34.6 & 35.4 & ns. \\
\hline
\end{tabular}

Means not sharing a common letter are significantly different $\mathrm{a}, \mathrm{b}(\mathrm{p}<0.05)$, ns. (non-significant). 
Table 5. Plasma selenium content $(\mathrm{mg} / \mathrm{l})$ in cows fed various Se diets (for group explanation see Table 1, p. 29).

\begin{tabular}{cccccc}
\hline Period & \multicolumn{5}{c}{ Group } \\
\cline { 2 - 6 } & 1 & 2 & 3 & 4 & \\
\hline I & 0.031 & 0.037 & 0.035 & 0.038 & ns. \\
II* $^{*}$ & $0.024^{\mathrm{a}}$ & $0.052^{\mathrm{b}}$ & $0.085^{\mathrm{c}}$ & $0.091^{\mathrm{c}}$ & \\
II** $^{* *}$ & $0.031^{\mathrm{a}}$ & $0.067^{\mathrm{b}}$ & $0.084^{\mathrm{c}}$ & $0.086^{\mathrm{c}}$ & \\
III & $0.034^{\mathrm{a}}$ & $0.084^{\mathrm{b}}$ & $0.100^{\mathrm{c}}$ & $0.111^{\mathrm{c}}$ & \\
IV & $0.031^{\mathrm{a}}$ & $0.073^{\mathrm{b}}$ & $0.087^{\mathrm{bc}}$ & $0.102^{\mathrm{c}}$ & \\
V & $0.033^{\mathrm{a}}$ & $0.058^{\mathrm{b}}$ & $0.082^{\mathrm{c}}$ & $0.089^{\mathrm{c}}$ & \\
VI & $0.018^{\mathrm{a}}$ & $0.020^{\mathrm{a}}$ & $0.027^{\mathrm{b}}$ & $0.030^{\mathrm{c}}$ & \\
\hline
\end{tabular}

* after 28 days supplementation

** after 56 days supplementation

For significances see Table 4, p. 48.

cantly affected by dietary treatment $(\mathrm{p}<0.05)$ and by time $(\mathrm{p}<0.001)$ (Table 5). The interaction between group and period affected plasma Se content $(\mathrm{p}<0.001)$ both when dietary Se level was increased and when it was decreased. This indicates that feed Se is taken up more efficiently by plasma and when cows are depleted plasma Se also remains higher in animals fed feed Se than in those fed inorganic Se.

The proportion (total plasma Se : daily Se intake) decreased with increasing dietary $\mathrm{Se}$ content, but there was no effect of dietary selenium source. During the selenium supplementation periods total plasma Se concentration was $1.43,0.48,0.54$ and 0.38 times the daily Se intake in the groups 1, 2, 3 and 4, respectively. Only group 1 differed from the others $(p<0.001)$. Age of cow, lactation stage or milk production had no effect on plasma Se content. Plasma albumin concentration $(\mathrm{p}<0.001)$ but not plasma total protein content affected plasma Se content. The following equation explained $68.1 \%$ of the variation in plasma selenium content:

$$
\begin{gathered}
\mathrm{Y}=-0.040+0.1150 \mathrm{X}_{1}-0.1041 \mathrm{X}_{1}{ }^{2}+ \\
0.1886 \mathrm{X}_{2}-0.1199 \mathrm{X}_{2}{ }^{2}+0.0019 \mathrm{X}_{3} \\
\text { where, } \mathrm{Y}=\text { plasma Se }(\mathrm{mg} / \mathrm{l}) \\
\mathrm{X}_{1}=\text { mineral Se intake }(\mathrm{mg} / \mathrm{kg} \mathrm{DM}) \\
\mathrm{X}_{2}=\text { feed Se intake }(\mathrm{mg} / \mathrm{kg} \mathrm{DM}) \\
\mathrm{X}_{3}=\text { plasma albumin }(\mathrm{g} / \mathrm{l}) .
\end{gathered}
$$

\subsubsection{Erythrocyte selenium}

Selenium source did not affect erythrocyte selenium content, even though the organic Se source tended to increase erythrocyte Se content more rapidly (Table 6). The interaction between group and period was significant both when increasing $(\mathrm{p}<0.001)$ and decreasing $(\mathrm{p}<0.01)$ dietary Se level indicating more efficient uptake and retention of Se in erythrocytes when feed $\mathrm{Se}$ was provided to the animals.

Table 6. Erythrocyte Se concentration (mg/l) in cows fed various Se diets (for group explanation see Table 1, p. 29).

\begin{tabular}{cccccc}
\hline Period & \multicolumn{5}{c}{ Group } \\
\cline { 2 - 6 } & 1 & 2 & 3 & 4 & \\
\hline I & 0.247 & 0.259 & 0.288 & 0.273 & ns. \\
II* $^{*}$ & 0.214 & 0.221 & 0.225 & 0.190 & ns. \\
II $^{* *}$ & $0.173^{\mathrm{a}}$ & $0.239^{\mathrm{b}}$ & $0.327^{\mathrm{c}}$ & $0.342^{\mathrm{c}}$ & \\
III & $0.155^{\mathrm{a}}$ & $0.360^{\mathrm{b}}$ & $0.416^{\mathrm{bc}}$ & $0.443^{\mathrm{c}}$ & \\
IV & $0.213^{\mathrm{a}}$ & $0.537^{\mathrm{b}}$ & $0.549^{\mathrm{b}}$ & $0.630^{\mathrm{b}}$ & \\
V & $0.209^{\mathrm{a}}$ & $0.366^{\mathrm{b}}$ & $0.441^{\mathrm{b}}$ & $0.536^{\mathrm{c}}$ & \\
VI & $0.096^{\mathrm{a}}$ & $0.187^{\mathrm{b}}$ & $0.221^{\mathrm{bc}}$ & $0.237^{\mathrm{c}}$ & \\
\hline
\end{tabular}

* after 28 days supplementation

** after 56 days supplementation For significances see Table 4, p. 48.

Both milk production and lactation stage were related $(p<0.01)$ to erythrocyte selenium content, but the effect seems to be due to lactation stage rather than actual production. Erythrocyte Se content was lowest two months post partum and reached maximum at seven months post calving whereupon it started to decrease. This indicates preferred use of Se for milk production and fetal growth. Neither age of the cow nor hematocrit affected erythrocyte Se content ( $p>0.05)$. Erythrocyte Se content plateaued at a $0.63 \mathrm{mg} / \mathrm{l}$ at dietary Se level of $1.82 \mathrm{mg} / \mathrm{kg} \mathrm{DM}$ and there was no clear difference between the selenium supplementation groups. The following equation explained $62.6 \%$ of the variation in erythrocyte content: 
$\mathrm{Y}=0.130+\mathrm{L}_{\mathrm{i}}+0.1408 \mathrm{X}_{1}+2.4075 \mathrm{X}_{2}$,

where $\mathrm{Y}=$ erythrocyte Se $(\mathrm{mg} / \mathrm{l})$

$\mathrm{X}_{1}=$ dietary Se intake $(\mathrm{mg} / \mathrm{kg} \mathrm{DM})$

$\mathrm{X}_{2}=$ plasma Se content $(\mathrm{mg} / \mathrm{l})$

$\mathrm{L}_{\mathrm{i}}=$ lactation stage

$$
\begin{aligned}
& \text { i: weeks } 1-13=0.289 \\
& \text { weeks } 14-30=0.350 \\
& \text { weeks 31- }=0.351 \\
& \text { dry period }=0.319
\end{aligned}
$$

Lactation weeks $1-13$ differed from lactation weeks $14-30$ and 31 - end $(p<0.05)$. The proportion of total daily Se intake $(\mathrm{mg} / \mathrm{d})$ which was retained in erythrocytes decreased with increasing Se intake $(\mathrm{p}<0.001)$. During the selenium supplementation periods erythrocytes retained an average of 5.32, 1.43, 1.86 and 1.36 the daily Se intake in the groups 1, 2,3 , and 4 , respectively. Only group 1 differed from the others $(p<0.001)$. Lactation stage affected the proportion of dietary Se retained in erythrocytes even more than it affected actual erythrocyte Se concentration. It was calculated that after eliminating the effect of Se intake erythrocytes retained 1.59, 2.62, 4.68 and 3.57 times the daily Se intake during lactation weeks $1-13,14-30,31-$ and dry period, respectively. Lactation weeks $1-13$ differed from lactation weeks 31 - end and the dry period, and lactation weeks 14-30 differed from lactation weeks $31-$ end $(\mathrm{p}<$ $0.05)$.

\subsubsection{Erythrocyte and plasma GSH-PX activity}

Erythrocyte GSH-Px activity in group 1 differed from that in Se supplemented groups and also differed between groups 2 and 4 $(\mathrm{p}<0.05$, Table 7). Selenium source had no significant effect. Se intake alone accounted for only $41.1 \%$ of the variation in erythrocyte GSH-Px activity even though both Se source and linear, quadratic and cubic components were included in the model. Erythrocyte Se content explained $61.2 \%$ of the variation in GSH-Px activity. Interaction between group and period in erythrocyte GSH-Px-
Table 7. Erythrocyte GSH-Px activity ( $\mu$ kat/1) in cows fed various Se diets (for group explanation see Table 1, p. 29)

\begin{tabular}{cccccc}
\hline Period & \multicolumn{5}{c}{ Group } \\
\cline { 2 - 6 } & 1 & 2 & 3 & 4 & \\
\hline I & 845 & 815 & 897 & 903 & ns. \\
II* $_{\text {II** }}^{715}$ & $785^{\mathrm{a}}$ & $861^{\mathrm{ab}}$ & $1017^{\mathrm{ab}}$ & $1056^{\mathrm{b}}$ & \\
III & $666^{\mathrm{a}}$ & $922^{\mathrm{b}}$ & $1047^{\mathrm{b}}$ & $1111^{\mathrm{b}}$ & \\
IV & $501^{\mathrm{a}}$ & $1244^{\mathrm{b}}$ & $1125^{\mathrm{b}}$ & $1253^{\mathrm{b}}$ & \\
V & $974^{\mathrm{a}}$ & $2818^{\mathrm{b}}$ & $3005^{\mathrm{b}}$ & $3175^{\mathrm{b}}$ & \\
VI & $1345^{\mathrm{a}}$ & $2189^{\mathrm{b}}$ & $2584^{\mathrm{bc}}$ & $2954^{\mathrm{c}}$ & \\
\hline
\end{tabular}

* after 28 days supplementation

** after 56 days supplementation

For significances see Table 4, p. 48.

activity was significant $(\mathrm{p}<0.001)$ both on increasing and decreasing dietary Se levels indicating better bioavailability and retention of feed Se as erythrocyte GSH-Px when compared to sodium selenite. Erythrocyte GSHPx activity did not reach a plateau within the range of experimental dietary Se content.

Age of the cow, lactation stage or milk production had no effect on erythrocyte GSH-Px activity, nor did any of the other determined minerals, trace elements or blood parameters.

The activity of GSH-Px-enzyme (kat/mol GSH-Px) was calculated using a molecular weight of $88000 \mathrm{U}$ and four Se atoms per unit (LADENSTEIN 1979). Furthermore the assumption that $75 \%$ of erythrocyte Se exists in GSH-Px-enzyme was made (OH et al. 1974, Sunde et al. 1978). This activity was 2464 , 2208, 2155 and $2101 \mathrm{~kat} / \mathrm{mol} \mathrm{GSH}-\mathrm{Px}$ in the groups 1, 2, 3 and 4, respectively. Only group 1 differed from the others $(\mathrm{p}<0.05)$.

Plasma GSH-Px activity averaged 2.7, 3.2, 3.2 and $3.8 \mu \mathrm{kat} / 1$ in the groups $1,2,3$, and 4 , respectively $(\mathrm{p}>0.05)$. Proportion of whole blood GSH-Px-activity associated with plasma was $0.89,0.54,0.46$ and $0.55 \%$ in groups $1,2,3$ and 4 , respectively. Only group 1 differed from the others $(\mathrm{p}<0.01)$. Plasma GSH-Px activity did not correlate with plasma Se, erythrocyte Se or GSH-Px, or Se intake, but it was negatively correlated with lactation stage $(\mathrm{p}<0.01)$. 


\subsubsection{Milk selenium}

Milk Se content differed $(\mathrm{p}<0.001)$ between groups, dietary organic Se being more effective $(p<0.001)$ in raising milk Se content than inorganic Se (Table 8). Calculated linear functions for the relationship between milk Se content (Y, mg/l) and dietary Se content (X, mg/kg DM) were for mineral Se and for feed Se $\mathrm{Y}=0.007+0.0160 \mathrm{X}$ and $\mathrm{Y}=0.011+$ $0.0256 \mathrm{X}$. The second degree polynomial functions were $\mathrm{Y}=0.007+0.0240 \mathrm{X}-0.000008 \mathrm{X}^{2}$ and $\mathrm{Y}=0.011+0.0441 \mathrm{X}-0.000015 \mathrm{X}^{2}$, respectively. The difference in linear components due to Se source was highly significant $(\mathrm{p}<0.001)$. The following equation explained $91.4 \%$ of the variation in milk Se content:

$$
\begin{aligned}
\mathrm{Y}= & 0.003+\mathrm{P}_{\mathrm{i}}+0.0131 \mathrm{~b}_{1}+0.1227 \mathrm{~b}_{2} \\
& -0.1549 \mathrm{~b}_{2}{ }^{2}+0.0654 \mathrm{~b}_{2}{ }^{3}
\end{aligned}
$$

where $\mathrm{Y}=$ milk Se content $(\mathrm{mg} / \mathrm{l})$

$$
\begin{aligned}
\mathrm{P}_{\mathrm{i}}= & \text { effect of experimental period } \\
& (\mathrm{i}=1 . .6) \\
\mathrm{b}_{1}= & \text { dietary mineral Se content }(\mathrm{mg} / \mathrm{kg} \\
& \text { DM) } \\
\mathrm{b}_{2}= & \text { dietary feed Se content }(\mathrm{mg} / \mathrm{kg} \\
& \text { DM) }
\end{aligned}
$$

Dietary Zn content was negatively correlated to milk Se content in cows fed inorganic

Table 8. Milk Se content $(\mathrm{mg} / \mathrm{l})$ in cows fed various Se diets (for group explanation see Table 1, p. 29).

\begin{tabular}{clcccc}
\hline Period & \multicolumn{5}{c}{ Group } \\
\cline { 2 - 6 } & \multicolumn{1}{c}{1} & \multicolumn{1}{c}{2} & 3 & 4 & \\
\hline I & 0.006 & 0.008 & 0.007 & 0.007 & ns. \\
II* $^{*}$ & $0.006^{\mathrm{a}}$ & $0.009^{\mathrm{a}}$ & $0.017^{\mathrm{b}}$ & $0.019^{\mathrm{b}}$ & \\
II** $_{\text {III }}$ & $0.008^{\mathrm{a}}$ & $0.011^{\mathrm{a}}$ & $0.020^{\mathrm{b}}$ & $0.025^{\mathrm{b}}$ & \\
IV & $0.008^{\mathrm{a}}$ & $0.016^{\mathrm{b}}$ & $0.029^{\mathrm{c}}$ & $0.034^{\mathrm{d}}$ & \\
V & $0.008^{\mathrm{a}}$ & $0.020^{\mathrm{b}}$ & $0.040^{\mathrm{c}}$ & $0.051^{\mathrm{d}}$ & \\
VI & $0.008^{\mathrm{a}}$ & $0.011^{\mathrm{b}}$ & $0.023^{\mathrm{c}}$ & $0.027^{\mathrm{d}}$ & \\
\hline
\end{tabular}

* after 28 days supplementation

** after 56 days supplementation

For significances see Table 4, p. 48.
Table 9. Proportion of dietary Se in milk $(\%)$ in cows fed various Se diets (for group explanation see Table 1, p. 29).

\begin{tabular}{rccccc}
\hline Period & \multicolumn{5}{c}{ Group } \\
\cline { 2 - 6 } & 1 & 2 & 3 & 4 & \\
\cline { 2 - 6 } I & 4.4 & 3.3 & 4.0 & 4.3 & ns. \\
II & $11.6^{\mathrm{b}}$ & $7.1^{\mathrm{a}}$ & $9.6^{\mathrm{a}}$ & $8.3^{\mathrm{a}}$ & \\
III & $19.7^{\mathrm{c}}$ & $4.4^{\mathrm{a}}$ & $9.4^{\mathrm{b}}$ & $5.7^{\mathrm{ab}}$ & \\
IV & $18.3^{\mathrm{b}}$ & $3.3^{\mathrm{a}}$ & $4.1^{\mathrm{a}}$ & $3.2^{\mathrm{a}}$ & \\
V & $35.0^{\mathrm{c}}$ & $13.3^{\mathrm{a}}$ & $28.7^{\mathrm{bc}}$ & $16.6^{\mathrm{ab}}$ & \\
VI & $14.0^{\mathrm{a}}$ & $17.8^{\mathrm{ab}}$ & $17.5^{\mathrm{ab}}$ & $20.2^{\mathrm{b}}$ & \\
\hline
\end{tabular}

For significances see Table 4, p. 48.

Se $(\mathrm{p}<0.01)$. Dietary $\mathrm{S}$ in cows fed inorganic $\mathrm{Se}(\mathrm{p}<0.01)$, and dietary $\mathrm{P}$ both in cows fed inorganic $(\mathrm{p}<0.05)$ and organic $\mathrm{Se}(\mathrm{p}<0.001)$ were positively related to milk Se.

An average of $0.050,0.047,0.059$ and $0.061 \%$ of plasma Se circulating through the mammary gland was extracted and secreted into milk in the groups $1,2,3$ and 4, respectively. Only group 2 differed from groups 3 and $4(p<0.05)$. Plasma Se $(p<0.001)$, plasma $\mathrm{Mg}(\mathrm{p}<0.01)$ and plasma cholesterol $(p<0.05)$ were negatively, and milk Se $(\mathrm{p}<0.001)$ and plasma $\mathrm{P}(\mathrm{p}<0.05)$ positively related to the transfer of plasma Se into milk. Thus a lower percentage of plasma Se was transferred into milk with increasing plasma Se content. There was no difference between the Se sources. Neither lactation stage, milk production nor age of a cow affected the Se transfer from plasma into milk.

The proportion of dietary Se transferred into milk was the greatest in group 1 (Table 9). The proportion of Se transferred into milk decreased with increasing dietary Se content, and with inorganic Se this decline was greater than with organic Se source $(\mathrm{p}<0.01)$. Dietary minerals and trace elements, milk production or composition, lactation stage or age of a cow were not related to the efficiency of Se transfer from diet into milk. 


\section{DISCUSSION}

This investigation attempts to elucidate metabolism of Se originating from inorganic and organic sources. In the present discussion feed sprayed with selenite before cutting is considered to be organic Se even though chemical form of Se in feed was not identified. Results from other investigations have revealed, however, that selenite-Se is incorporated into amino acids and further into plant proteins in less than 30 minutes (e.g. PEterSON and ButLer 1962, Shrift 1969, GisselNielsen 1976).

Results from goats are generally regarded applicable to cows even though DEBSKI et al. (1987) reported some discrepancies in selenium metabolism. However, goats were dosed with radioactive tracer in the present study, because the use of dairy cows in this part was beyond the facilities.

Because the intraruminal dose of selenite in phase I of experiment 2 failed in one of the goats, only one observation for this treatment is available. These results should therefore be considered a demonstration of the principles prevailing in selenium metabolism, even though vigorous statistical evaluation is not possible. Both experiments involved principally the same treatments and were well in line thus increasing reliability of the results. The length of the follow-up periods and sampling frequency were not identical in two goat experiments. Several tissue Se pools contribute to excretion of Se in milk, urine and faeces. Thus the length of follow-up period and sampling frequency significantly affect the rate constants obtained. Shorter sampling intervals towards the end of the follow-up period would have improved the accuracy of calculated rate constants, but probably would not have affected total excretion values, because most of ${ }^{75} \mathrm{Se}$-label was excreted during the first days after dosing.

Radioactive measurements from milk, urine and faeces were counted in triplicate, from plasma in duplicate and from erythrocytes in singlet. Erythrocyte ${ }^{75} \mathrm{Se}$ values are thus the least reliable particularly the samples that had to be diluted to obtain equal geometry in counting. Also plasma contamination may have interfered with determined ${ }^{75} \mathrm{Se}$ activities in erythrocytes during the first days after dosing. In experiment 2 attempt was made to avoid inaccuracy due to plasma contamination by measuring hematocrit in the erythrocyte suspension. Counting errors for ${ }^{75} \mathrm{Se}$ activity ranged mainly between one and two percent and only in a very few cases exceeded five percent. Accurate figures were thus available for calculations.

Roughage was fed to the cows as a group, which caused some inaccuracy in estimating dietary mineral and trace element intake. Therefor no significances concerning diets are given, although average values are suspected to represent true intake. The cows were sampled for blood parameters and milk Se content only once during each experimental period except during the first two periods when they were sampled twice. Variation in samples taken during the period I were insignificant, but during the period II parameters describing Se status of the cows changed considerably between the two samples in cows supplemented with Se indicating that the length of Se supplementation has to be considered carefully. Unequal length of supplementation periods 
may thus have biased the calculated relationship between dietary Se content and the parameters describing Se status of the cows.

More detailed investigations including the identification of chemical forms of seleno compounds in the course of metabolism should be conducted to confirm the conclusions made from the present data.

\subsection{Absorption of Se}

The apparent absorption of Se in this study varied from 46.6 to $62.5 \%$ for feed Se and $31.2 \%$ to $61.5 \%$ for selenite, in accordance with several other studies. Values of $46 \%$ (NEATHery et al. 1987) and $51 \%$ (van RySSEN et al. 1987) have been found in calves fed low selenium diets, and values range from $36 \%$ to $51 \%$ in dairy cows fed supplemented rations (Harrison and Conrad 1984a, 1984b). In sheep apparent absorption of Se has been reported to vary from $44 \%$ to $51 \%$ (POPE et al. 1979, SharifF and Khrisnamurti 1987, ZANETTI et al. 1987). Results of apparent selenium absorption vary considerably between studies and values as low as $11 \%$ have been reported in dairy cows (KoENIG et al. 1989) with $0.19 \mathrm{mg} \mathrm{Se} / \mathrm{kg}$ DM intake. This low value was, however, obtained with a technique which differs from those used most commonly. On the other hand as high as 97 $\%$ apparent absorption of Se in depleted sheep has been reported (SharifF and KhrisnamurTI 1987). Though the available data on selenium absorption are relatively abundant, most of the results are not applicable to ruminants. Absorption values obtained for monogastric animals and humans mainly range between $90 \%$ and $100 \%$ (e.g. Brown et al. 1972, Thomson et al. 1975, RAHIM et al. 1986). However, lower values in long term experiments have been also reported (RoBINSON et al. 1978).

True absorption of Se was similar from both inorganic and organic Se sources as well as from various dietary Se levels. True absorption in experiment 1 was $64.5 \%$. In experiment 2 true absorption for feed $\mathrm{Se}$ was
$63.3 \%$, but for inorganic Se was only $37.0 \%$. However, the value for inorganic Se in experiment 2 is based on data from only one goat and thus may not be reliable. This value was significantly lower $(\mathrm{p}<0.01)$ than the value obtained in experiment 1 for inorganic Se. Thus, if the result from experiment 2 for inorganic Se represents the real situation, the low absorption of inorganic Se could be due to a reduction of selenite to elemental Se or other insoluble forms of Se, such as metal selenides (Pope et al. 1979). The total amount of ${ }^{75} \mathrm{Se}$ excreted during the follow-up period for this goat ( $92.1 \%$ of the dose) was well above other types of dosing (range from 43.5 to $83.2 \%$ ) indicating that this might be the case.

LANGLANDS et al. (1986) speculated based on their results in sheep that Se entering faeces had been reduced to unavailable forms, such as elemental Se during passage through the rumen. The quantity of Se reduced depends on the quantity of organic matter fermented in the rumen and is thus related to organic matter intake. This is partly supported by the findings of PETER et al. (1985), but not by results from HARRISON and CONRAD (1984b). In the present study dry matter intake was on the average $77 \mathrm{~g} / \mathrm{kg} \mathrm{W}^{0.75}$ in both experiments and thus cannot be the cause for the differences in absorption. An inactive carrier was used in experiment 2 , but not in the experiment 1. Apart from using carrier, the procedures in the experiments were very similar. The total amount of intraruminally dosed Se was less than half of the total daily Se intake in experiment 2 and should thus not have disturbed absorption of selenite. It would have been expected to decrease reduction of labeled selenite to selenides in the rumen rather than the other way around. However, benefits and disadvantages of using carrier in this kind of study have to be carefully considered. Another possible reason, even though unlikely, for lowered Se absorption of ${ }^{75} \mathrm{Se}$-selenite with selenite feeding might be a saturation of the selenite absorption system. However, absorption of selenite is primarily by passive 
diffusion (Wolffram et al. 1985, 1986), and LOPEZ et al. (1968) did not find any decrease in Se absorption when feeding selenite diets containing Se up to $5 \mathrm{ppm}$ to lambs.

The goats in experiment 2 excreted almost three times as much of the intravenously dosed ${ }^{75} \mathrm{Se}$ in faeces as the goats in experiment 1 $(\mathrm{p}<0.001)$. However, there was no difference in faecal excretion due to the selenium source. In experiment 1 selenium deficient and supplemented goats excreted equal amounts of intravenously dosed ${ }^{75} \mathrm{Se}$ in faeces. The different length of the follow-up period does not explain the discrepancy between the experiments because about $95 \%$ of excretion occurred during the first two weeks. Endogenous faecal excretion was similar to that obtained in most other studies with values of $11 \%$ to $23 \%$ in sheep (LANGLANDS et al. 1986), $5 \%$ in lambs (Lopez et al. 1968) and 8 to $17 \%$ in cows (Symonds et al. 1981a). Earlier results from monogastric animals are around $10 \%$ (e.g. Burk et al. 1972, Thomson and Stewart 1973, HanSEN and Kristensen 1979, KRISTENSEN and HANSEN 1980) varying less than results from ruminants.

In most studies dietary Se level has not affected proportion of endogenous Se excreted in faeces (LOPEZ et al. 1968, BURK et al. 1972), but Shariff and Khrisnamurti (1989) reported increased endogenous faecal excretion in Se supplemented sheep. The source of $\mathrm{Se}$ affected endogenous excretion of $\mathrm{Se}$ in dairy cows (SymONDS et al. 1981a), but not in rats (Thomson and Stewart 1973). Arsenite has been reported to increase dramatically selenium excretion in bile in rats (4 to $40 \%$ ) (LeVANDER and BaumanN 1966), but not in sheep (LANGLANDS et al. 1986). The main route for endogenous Se secretion in sheep is reported to be saliva (DEJNEKA et al. 1979) with other important routes being bile and digestive juices (HANSSON and BLAU 1963, IMBACH and SternBerg 1967, Hidiroglou and Jenkins 1974, Symonds et al. 1981b). The anterior part of the small intestine is reported in some studies to be the main site for Se secretion (Wright and Bell 1966, Hidiroglou and JenKins 1974, LANGLANDS et al. 1986). In the present study the transit time for ${ }^{75} \mathrm{Se}$ in faeces was shorter after an intravenous dose than after oral or intraruminal doses supporting the conclusion that secretion mainly occurs in anterior part of the small intestine.

\subsection{Selenium in blood and hair}

In cows fed selenited feed a plateau in plasma Se content was calculated to occur at 0.113 $\mathrm{mg} \mathrm{Se} / 1$, but in cows fed inorganic Se plasma plateaued at a slightly lower level. Unequal intakes of inorganic and organic dietary Se caused some discrepancies in calculating the dietary level at which plasma Se plateaus, but after equalizing the range of dietary Se intake a plateau was calculated to be reached at approximately $0.5 \mathrm{mg} \mathrm{Se} / \mathrm{kg} \mathrm{DM}$. Previous research reports that a plateau occurs in dairy cows between 0.10 and $0.12 \mathrm{mg} \mathrm{Se} / 1$ plasma (WAite et al. 1975, MaUs et al. 1980). Feeding cows Se up to $100 \mathrm{mg} / \mathrm{d}$ as selenite raised this level only to $0.14 \mathrm{mg} / \mathrm{l}$ (FISHER et al. 1980). Stevens et al. (1985) reported an extremely high value $(0.78 \mathrm{mg} / \mathrm{l})$ in grazing cattle. Values in that range, however, are not supported by any other investigations.

In the present study goats fed Se at levels of 0.34 and $0.38 \mathrm{mg} \mathrm{kg} / \mathrm{DM}$ had an average plasma Se content of $0.16 \mathrm{mg} / 1$. The proportion of plasma Se excreted in milk and urine decreased rapidly during the first two days and slowly thereafter. The subsequent change to predominantly faecal excretion was not so clear due to long retention time in gut. However, plasma Se removed to faeces was better related to endogenous excretion of Se than erythrocyte Se removed to faeces.

In cows erythrocyte Se content decreased during the first weeks of the first Se supplementation period, which probably was due to the slight decrease in dietary Se content which was necessary to adhere to standard recommendations during the two months preceding the experiment. Because the turnover in erythrocyte $\mathrm{Se}$ content is known to be slow (Whanger and Beilstein 1986a), the ef- 
fect of the dietary changes appeared after a lag period. Depressed erythrocyte Se content towards the end of gestation observed in the present study is probably due to retention of $\mathrm{Se}$ in fetus, which is reported to sequester blood Se from the dam with higher priority than dam's own tissues (Koller et al. 1984).

Even though differences in erythrocyte GSH-Px between the groups fed either inorganic or feed Se were not significant, interaction between the Se source and dietary Se level indicated that feed Se maintains erythrocyte GSH-Px activity better than inorganic Se when cows are depleted. The slight difference between the sources when increasing dietary Se levels were fed may be due to unequal $\mathrm{Se}$ intake in the groups. Pehrson et al. (1989) have demonstrated in heifers that organic $\mathrm{Se}$ increases erythrocyte GSH-Px activity more efficiently than inorganic Se. The opposite has been reported in pigs (SANKARI 1985).

During the periods V and VI when Se intake was gradually reduced the activity of GSH-Px enzyme (activity kat/mol of GSH$\mathrm{Px}$ ) was markedly increased indicating either changes in the enzyme activity itself or preferred retention of Se in the GSH-Px enzyme instead of other selenoproteins. The main reason for poor correlation of Se intake with erythrocyte GSH-Px activity was the time required for depletion during the periods when decreasing dietary Se levels were fed, even though these periods lasted about four months. ButLER et al. (1990) reported that in the rhesus monkey erythrocyte GSH-Px activity was saturated in 4.5 months when animals were fed selenomethionine, but not within 8 months when selenite was the source of selenium. When rats were depleted, GSH-Px activity decreased more slowly in those animals which had been supplemented with selenomethionine than in those supplemented with selenite (BEILstein and Whanger 1986a). A correlation between dietary Se and erythrocyte GSH-Px activity has been demonstrated in sheep (OH et al. 1976, WhANGer et al. 1977), in cattle (Thompson et al. 1976, Hoffman et al. 1978), in pigs (CHAvEz 1979) and in rats
(HAFEmAn et al. 1979), but not in humans (ButLer et al. 1982). Generally when dietary Se intake is low, the correlation between dietary Se and erythrocyte GSH-Px is poor (Whanger et al. 1977).

The proportion of total GSH-Px activity in blood associated with plasma, ranging in the present study between $0.5 \%$ and $0.9 \%$, is well in line with earlier studies which report the proportion to be about one per cent (CARLSTRÖM 1979).

In experiment 1 only ${ }^{75} \mathrm{Se}$ activity in hair was measured, but no attempt was made to estimate the growth of hair so it is not possible to calculate deposition. There were no differences due to dietary Se level in hair ${ }^{75} \mathrm{Se}$ activity and, because of the fact that growth of hair occurs within the skin, comparing of sources during this short-term experiment may not be valid. In experiment $2,{ }^{75} \mathrm{Se}$ retention in hair was similar whether goats were dosed orally selenited grass or I.R. selenite, but after I.V. dose more of ${ }^{75} \mathrm{Se}$ was retained in hair when dosed as selenomethionine than as sodium selenite. In rats selenomethionine was two to three times more efficient than sodium selenate in raising Se content in hair, but dietary methionine content affected retention of $\mathrm{Se}$ in both sources (SAlbe and Levander 1990).

\subsection{Excretion of $\mathrm{Se}$ in urine}

${ }^{75} \mathrm{Se}$ excretion in urine was low in depleted goats $(5.7 \%$ of a dose and $11.4 \%$ of excreted $\mathrm{Se})$ which is in agreement with results from other studies (HopKINS et al 1966, LoPEZ et al 1968, BURK et al. 1972). A value as high as $50 \%$ has been reported (LANGLANDS et al 1986), but the high excretion value was obtained by using a different technique from the present one. Goats dosed with ${ }^{75} \mathrm{Se}$-selenite excreted about twice as much of the dose in urine as goats dosed with an organic source of ${ }^{75} \mathrm{Se}$, whether the calculation was based on actual excretion or on the excretion of truly absorbed ${ }^{75} \mathrm{Se}$. 
Differences due to selenium source in urinary Se excretion have been evident both at low and high Se intakes (THOMSON and Stewart 1973, Nahapatian et al. 1983, FosTER et al. 1986b). On a low Se intake (0.05 $\mathrm{ppm}$ ) urinary excretion of Se in rats was about $4 \%$ and $13 \%$ of orally administered selenomethionine and selenite, respectively. Excretion of intravenous doses was slightly higher (Thomson and Stewart 1973). With adequate Se intake $(0.25 \mathrm{ppm})$ about $30 \%$ of selenomethionine, $40 \%$ of selenocysteine and $45 \%$ of selenite were excreted in urine in rats $\mathrm{N}_{\mathrm{A}}$ HAPATIAN et al. 1983).

In the present study, excretion of intravenously dosed ${ }^{75} \mathrm{Se}$-selenomethionine in urine increased linearly with increasing dietary Se content $(\mathrm{p}<0.05)$. Excretion of feed ${ }^{75} \mathrm{Se}$ did not increase above a dietary Se content of $0.22 \mathrm{mg} / \mathrm{kg} \mathrm{DM}$, whether the calculations were based on actual excretion or on excretion of truly absorbed ${ }^{75} \mathrm{Se}$. The excretion pattern for selenite was similar when the calculations were based on actual excretion, but not when they were based on the excretion of truly absorbed ${ }^{75} \mathrm{Se}$. Excretion of truely absorbed selenite increased linearly with increasing dietary Se content. This is probably more accurate because the lowered absorption with the high selenite intake obtained in experiment 2 leads to underestimated actual excretion values.

Increased urinary excretion of ${ }^{75} \mathrm{Se}$ with increased Se intake is in agreement with several other studies reporting that urinary Se excretion was 40 to $67 \%$ of the dose at high Se intakes (e.g. BURK et al. 1972 and 1973, LoPEZ et al. 1968, HANSEN and KRISTENSEN 1979, Alfaro et al. 1987).

Results in rats vary concerning the effect of the Se dose on urinary Se excretion. Some of the studies report no dose-dependency (e.g. Hopkins et al. 1966, PALMER et al. 1970, KRISTENSEN and HANSEN 1980), while others show dose-dependency at physiological levels but not at higher levels (BURK et al. 1972). NAHAPATIAN et al. (1983) reported an absence of dose dependency for selenomethionine and selenocysteine, whereas selenite excretion in urine decreased with increasing Se dose. These discrepancies are most likely due to volatilization of Se at high doses. Thus a very high dose may result in a rather low percentage of injected Se being excreted in urine. Most of Se dose is exhaled as dimethylselenide, which is an intermediate product in the TMSe pathway. TMSe is the main urinary Se metabolite when Se is fed at high levels (PALMer et al. 1969).

Based on regression analysis of data from dosing with organic sources of Se, excretion of intravenously-given Se in urine exceeded that of orally-given Se at a dietary Se level of $0.13 \mathrm{mg} / \mathrm{kg}$ DM. Plasma Se plateaus at about this dietary Se level and thus the ability of plasma to bind Se may be exceeded with the excess Se being filtered by the kidneys. However, with increased dietary Se, a large proportion of the Se excreted in urine was excreted towards the end of follow-up period. BURK et al. (1973) studied the dietary threshold for urinary excretion and found it to be between 0.05 and $0.08 \mathrm{ppm}$ above which the percentage of the dose excreted in urine increased up to at least a level of $1 \mathrm{ppm}$ (BURK et al. 1972). They speculated that the increase in urinary excretion is probably related to metabolic production of substances such as TMSe or that the renal threshold for these metabolites may be altered. This is not supported by NAHAPATIAN et al. (1983) using selenomethionine, selenocysteine and selenite.

In the present study ${ }^{75} \mathrm{Se}$ clearance from plasma to urine was dependant on a dietary Se level and time, but for the most part not on Se source. The most distinct discrepancy between the sources occurred after the intravenous dose at a high dietary Se level with much higher clearance of selenite than selenomethionine ( $550 \mathrm{vs} .150 \mathrm{ml} / \mathrm{h}$ ) during the first 8 hours post dosing. After $24 \mathrm{~h}$ the clearance for both sources was equal, about $30 \mathrm{ml} / \mathrm{h}$. When dietary Se level was increased from 0.05 $\mathrm{mg} / \mathrm{kg} \mathrm{DM}$ to $0.22 \mathrm{mg} / \mathrm{kg} \mathrm{DM}$ the rate of clearance increased 4 to 6 times, but there was no further increase above the Se level of 0.22 
$\mathrm{mg} / \mathrm{kg}$ DM. After an oral or intraruminal dose the plasma clearance in supplemented goats decreased from about $230 \mathrm{ml} / \mathrm{h}$ during the first hours to about $24 \mathrm{ml} / \mathrm{h}$ and in depleted goats from about $100 \mathrm{ml} / \mathrm{h}$ to $4 \mathrm{ml} / \mathrm{h}$. In depleted goats after I.V. dose of selenomethionine plasma clearance never exceeded $75 \mathrm{ml} / \mathrm{h}$ and in $8 \mathrm{hrs}$ it fell below $5 \mathrm{ml} / \mathrm{h}$ reaching a level of about $2 \mathrm{ml} / \mathrm{h}$ few days later. Thus regardless of dosage route depleted goats cleared much less $\mathrm{Se}$ from plasma than supplemented goats.

The dose of ${ }^{75} \mathrm{Se}$ contained less than $10 \mu \mathrm{g}$ of Se which contributed roughly $10 \%$ excess Se to plasma in depleted goats and even less in supplemented goats. Se which exceeds the binding capacity of plasma is rapidly taken up by tissues, most notably liver and kidney, and is processed to compounds which may be retained in the body and released later in the continuous turnover of body Se pool (SyMONDS et al. 1981b, BEILSTEIN et al. 1984). ZeISEL et al. (1987) speculated based on their results in the rat that production of TMSe is dose dependant, but excretion of a single dose was dependant on the previous Se intake. This is not supported by the findings of the present study, probably because ZeISEL et al. (1987) were operating at relatively high Se intakes, their lowest Se level being about at the same as the highest level in the present study. Above the level of $0.2 \mathrm{mg} \mathrm{Se} / \mathrm{kg} \mathrm{DM}$ there was a tendency for decreasing plasma clearance to urine after both oral and intraruminal doses, but not after intravenous doses. Thus the speculation of ZEISEL et al. (1987) could be valid, but only when intake of Se is in a range which more closely approximates requirements.

\subsection{Excretion of selenium in milk}

In goats neither actual excretion of feed incorporated ${ }^{75} \mathrm{Se}$ in milk, varying from $6.7 \%$ to $8.1 \%$ of the dose, proportion of total ${ }^{75} \mathrm{Se}$ excretion excreted in milk, varying from $11.3 \%$ to $13.2 \%$, nor excretion of truly absorbed ${ }^{75} \mathrm{Se}$, varying from $10.2 \%$ to $12.7 \%$, were dependant on dietary Se level. The actual excretion of I.V. dosed ${ }^{75} \mathrm{Se}$-selenomethionine in milk also was not dependant on Se intake. However, when expressed as a proportion of total excretion, relatively less ${ }^{75} \mathrm{Se}$ was excreted in milk with increasing dietary Se level due to higher urinary ${ }^{75} \mathrm{Se}$ losses $(76.4 \%, 52.8 \%$ and $38.7 \%$ at dietary Se levels 0.05, 0.22 and $0.34 \mathrm{mg} \mathrm{Se} / \mathrm{kg} \mathrm{DM}$, respectively). Higher ${ }^{75} \mathrm{Se}$ excretion in milk after an I.V. dose than after an oral dose was due primarily to excretion very shortly after the I.V. dose. With higher Se intake more of dosed Se is metabolized to compounds which are not excreted to milk, but are excreted in urine (NAHAPETIAN et al. 1983).

Maximum excretion in milk tended to occur earlier with increasing dietary Se level both with feed-incorporated ${ }^{75} \mathrm{Se}$ and ${ }^{75} \mathrm{Se}$-selenite. There was no difference in $k_{1}$ or $k_{2}$ due to dietary selenium levels, but the slowest component $\left(\mathrm{k}_{3}\right.$ or $\left.\mathrm{k}_{4}\right)$ tended to be faster with increasing selenium intake. Length of sampling period and sampling interval play an important role in determining rate constants in this kind of study, where several pools are contributing to the sampled pool. Selenium content in different tissues varies greatly and a given tissue may contribute to several pools (Burk et al. 1972, BeHne and Höfer-Bosse 1984). A longer follow-up period would enable determination of the slowest turnover rate, and more frequent sampling in the early phases would allow closer determination of $\mathrm{k}_{1}$ and $\mathrm{k}_{2}$.

After an oral dose of ${ }^{75} \mathrm{Se}$-labeled grass in depleted goats, milk ${ }^{75} \mathrm{Se}$ activity only slightly exceeded that of plasma for the first four hours; thereafter ${ }^{75} \mathrm{Se}$ activity in milk was lower than in plasma. At dietary Se levels of 0.22 and $0.34 \mathrm{mg} \mathrm{Se} / \mathrm{kg} \mathrm{DM}$, milk ${ }^{75} \mathrm{Se}$ activity was above plasma ${ }^{75} \mathrm{Se}$ activity until 24 and $30 \mathrm{hrs}$, respectively. This indicates that organic selenium is at least partly transferred into milk by some active process thus confirming results from JENKINS and Hidiroglou (1971). The ratio of ${ }^{75} \mathrm{Se}$ in milk to ${ }^{75} \mathrm{Se}$ in plasma was dependant on dietary selenium 
level. Generally changes in milk ${ }^{75} \mathrm{Se}$ : plasma ${ }^{75} \mathrm{Se}$ ratios during the first $12 \mathrm{hrs}$ were not great. A plateau was reached at 6,8 and 9 days post dosing at ratios $0.09,0.10$ and 0.15 for dietary Se levels of $0.05,0.22$ and $0.34 \mathrm{mg} / \mathrm{Se}$ $\mathrm{kg} \mathrm{DM}$, respectively, $(\mathrm{p}<0.01)$.

Plasma ${ }^{75} \mathrm{Se}$ was transferred into milk on the average 1.5 times more efficiently after an I.V. dose than after an oral dose of ${ }^{75} \mathrm{Se}$. At highest Se intake ${ }^{75} \mathrm{Se}$ activity was 25 times higher in milk than in plasma one hour after dosing with I.V. ${ }^{75} \mathrm{Se}$-selenomethionine. In depleted goats the maximum concentration in milk was only four times higher than in plasma. Milk ${ }^{75} \mathrm{Se}$ : plasma ${ }^{75} \mathrm{Se}$ ratios, however, decreased rapidly after the I.V. dose and 20 hrs post dosing were less than one at each Se level. Plateaus in these ratios were reached in depleted goats 10 days post dosing, but in supplemented goats not until two weeks post dosing. The heights of these plateaus were about 1.5 times higher than after the oral dose.

Enhanced efficiency of plasma Se transfer into milk with increasing dietary Se content might reflect saturation of plasma Se concentration which is reported to occur about at the level of $0.1 \mathrm{mg} / 1$ (WAITE et al. 1975, MAUS et al. 1980). However, this saturation was not found in the present goat experiments; goats fed $0.34 \mathrm{mg}$ organic $\mathrm{Se} / \mathrm{kg} \mathrm{DM}$ and $0.38 \mathrm{mg}$ inorganic $\mathrm{Se} / \mathrm{kg} \mathrm{DM}$ had average plasma $\mathrm{Se}$ concentrations of $0.17 \mathrm{mg} / 1$ and $0.16 \mathrm{mg} / \mathrm{l}$, respectively

Excretion of intraruminally dosed ${ }^{75} \mathrm{Se}$ selenite in milk also was similar (5.3\% to $6.6 \%$ ) at all Se intakes when calculated based on truly absorbed ${ }^{75} \mathrm{Se}$. MAUS et al. (1980) reported milk Se content to be linearly related to dietary Se intake up to the level of 0.3 $\mathrm{mg} / \mathrm{kg}$, but not above that. This was, however, because of their use of an experimental ration which contained a high level of natural feed Se and this diet was supplemented with sodium selenite.

Excretion of ${ }^{75} \mathrm{Se}$-selenite in milk after an intravenous dose was similar to that after an intraruminal dose. However, excretion of intravenous ${ }^{75} \mathrm{Se}$-selenite in milk was only about $10 \%$ that of selenomethionine.

When inorganic selenium was administrated intraruminally, the lowest milk ${ }^{75} \mathrm{Se}$ : plasma ${ }^{75} \mathrm{Se}$ ratios were reached at 1,4 and 6 days at dietary Se levels $0.05,0.22$ and 0.38 $\mathrm{mg} \mathrm{Se} / \mathrm{kg} \mathrm{DM}$, respectively. The ratios were lower for depleted goats than for supplemented goats. After reaching minimums the ratios began to increase until 14 days, probably due to the release of selenocompounds from some slow turnover pool and having greater $\mathrm{k}_{\mathrm{m}}$-value for excretion in milk.

A milk-Se plateau was reached at $20 \mathrm{hrs}$ after the I.V. dose of ${ }^{75} \mathrm{Se}$-selenite. The increase in milk ${ }^{75} \mathrm{Se}$ : plasma ${ }^{75} \mathrm{Se}$ ratios found after the I.R. dose was not discernible after the I.V. dose of selenite. Enhanced transfer of plasma Se into milk with increased dietary Se level was greater when organic forms of Se were used.

In cows the correlation between dietary Se content and milk Se content was high $(\mathrm{p}<$ 0.001 ) both with organic (r: 0.85) and inorganic Se ( $r$ : 0.79). This is in agreement with results from PERRY et al. (1977) on selenite (r: 0.94) and Conrad and Moxon (1979) on selenite (r: 0.77) and on brewers grain (r: 0.89) (Conrad and Moxon 1979). Fisher et al. (1980), did not find a correlation between dietary Se content and milk Se content, but the 8 days supplementation period in that study was probably insufficient.

Plateaus in milk Se content were reached at 0.025 and $0.043 \mathrm{mg} / \mathrm{l}$ in cows fed mineral and feed selenium, respectively. It was anticipated that a plateau in milk Se would be reached at a dietary level of $1.5 \mathrm{mg} \mathrm{Se} / \mathrm{kg} \mathrm{DM}$ with both Se sources. However, in the group receiving both mineral and feed selenium supplementation at high levels $(1.8 \mathrm{mg} / \mathrm{kg}$ DM) milk Se content exceeded the expected plateau level. This suggests either some disturbance in Se secretion in milk as speculated by FISHER et al. (1980) or that secretion of inorganic and organic selenium into milk does not share the same route and thus saturation occurs at higher level. Derivation of third degree polynomial functions fitted on the data indicated 
that some kind of anomaly occurs in the transfer of Se into milk, because derivatives neither for organic nor for inorganic Se have any solution. A second degree polynomial function fitted on the data, gives a plateau for both Se sources, but fails to explain the effect of using both forms of Se-supplementation.

In cows fed organic selenium blood Se circulating through the mammary gland was removed about 1.5 times more efficiently than in cows receiving inorganic supplementation. The difference was thus more apparent in goats than in cows. This could be due to differences in the distribution of Se in milk of goats and cows (DEBSKI et al. 1987).

Maus et al. (1980) concluded that cows fed sufficient Se up to a level of $0.6 \mathrm{ppm}$ excrete $15 \%$ of dietary Se in milk, but above that level only $7-10 \%$. They were, however, supplementing a diet containing $0.33 \mathrm{mg} \mathrm{Se} / \mathrm{kg}$ DM natural selenium, which thus resulted in relatively high concentrations in milk. If the basal diet had contained less natural feed Se, much less of the Se would have been transferred to milk (e.g. at a level of $0.77 \mathrm{mg} / \mathrm{Se}$ $\mathrm{kg}$ DM about $1.5 \%$ of added Se). Based on their results they concluded that milk Se content plateaus at $0.06 \mathrm{ppm}$. FiSHER et al. (1980) did not notice this plateau in their experiment in which they were operating at Se dietary levels up to $10 \mathrm{ppm}$. They concluded that above toxic Se levels secretory controls may be overridden and more Se may be transferred into milk. They regarded selenite as a safer supplementation form for dairy animals, because milk Se content was less responsive to dietary selenite unless a toxic amount of selenite was used.

Milk Se content was positively related to plasma (r: $0.78, \mathrm{p}<0.001)$ and erythrocyte Se content ( $\mathrm{r}: 0.83, \mathrm{p}<0.001)$ and to milk protein content $(\mathrm{r}: 0.23, \mathrm{p}<0.01)$. Milk $\mathrm{Se}$ is bound almost entirely to proteins (JENKINS and Hidiroglou 1971, Khirwar and Arora 1977). All correlations were higher in organic Se than in inorganic Se groups.

Calcium intake was positively correlated to milk Se content, but this is due at least partly to high $\mathrm{Ca}$ content in the inorganic Se supplement. However, this correlation was also found in animals not receiving the selenium preparation. Dietary Ca content may affect Se absorption (HARRISON and CONRAD 1984b). With organic selenium $\mathrm{Zn}$ intake was negatively $(\mathrm{r}:-0.37, \mathrm{p}<0.01)$ correlated to milk Se content. Sword et al. (1984) did not, however, find any effect of $\mathrm{Ca}$ and $\mathrm{Zn}$ on whole blood Se content or utilization of Se. 


\section{GENERAL CONCLUSIONS}

True absorption from inorganic and organic sources of selenium is similar and is not affected by dietary selenium level.

Organic selenium is more efficient in increasing plasma selenium content and selenium-supplemented animals maintain plasma selenium levels longer when depleted. Inorganic and organic selenium sources are similar in their ability to increase erythrocyte selenium content.

The efficiency of inorganic and organic selenium in increasing erythrocyte GSH-Pxactivity is similar, but previous organic selenium supplementation results in higher GSHPx-activity when animals are depleted. Erythrocyte GSH-Px-activity did not reach a plateau with selenium supplementation which was below toxic levels.

About twice as much selenium was eliminated in urine after dosing with inorganic selenium as after dosing with organic selenium.
Organic selenium supplementation results in greater selenium content in milk than inorganic selenium supplementation. When selenium-supplemented cows were depleted, animals fed natural selenium containing feed maintained milk selenium better than animals fed inorganic selenium.

In order to raise milk selenium content to the level of $0.020 \mathrm{mg} \mathrm{Se} / 1$, which was regarded by the group to be sufficient, animals must be fed either $0.7 \mathrm{mg} / \mathrm{kg}$ DM inorganic selenium or $0.1 \mathrm{mg} / \mathrm{kg}$ DM organic selenium.

Organic selenium supplementation is safe and more efficient than inorganic selenium and does not risk toxic selenium intake by consumers, because milk selenium content plateaus with high dietary levels.

This kind of methodology is able to provide information on overall selenium metabolism. Identifying chemical forms of various selenium metabolites would be desirable in subsequent studies to confirm those results which remain only as speculations. 


\section{References}

Alfaro, E., Neathery, M.W., Miller, W.J., Gentry, R.P., Crowe, C.T., Fielding, A.S., Etheridge, R.E., Pugh, D.G. \& Blackmon, D.M. 1987. Effects of varying the amounts of dietary calcium on selenium metabolism in dairy calves. J. Dairy Sci. 70:831 - 836 .

Alfthan, G. \& Kumpulainen, J. 1982. Determination of selenium in small volumes of blood plasma and serum by electrothermal atomic absorption spectrmetry. Analytica Chimica Acta 140:221-227.

Allen, J.C. \& Miller, W.J. 1980. Selenium binding and distribution in goat and cow milk. J. Dairy Sci. 63: 526-531.

— \& Miller, W.J. 1981a. Mechanism for selenium secretion into milk. Feedstuffs 53: (5) 22-23.

- \& Miller, W.J. 1981b. Transfer of selenium from blood to milk in goats and noninterference of copper with selenium metabolism. J. Dairy Sci. 64:814821.

Amiot, J., Janghorbani, M., Young, V.R. 1982. Absorption and retention of ${ }^{75} \mathrm{SeSeO}_{3}{ }^{2-}$. Biochim. Biophys. Acta 372:255-265.

ANON. 1974. Recommended methods for the determination of four enzymes in blood. The committee on enzymes of the Scandinavian Society for Clinical Chemistry and Clinical Physiology. Scand. J. Clin. Lab. Invest. 33:291-306.

ANON. 1976. Recommended methods for the determination of $\gamma$-glutamyltransferase in blood. The committee on enzymes of the Scandinavian Society for Clinical Chemistry and Clinical Physiology. Scand. J. Clin. Lab. Invest. 36:119-125.

Anundi, I., Högerg, J. \& StäHL, A. 1984. Absorption of selenite in the rat small intestine: interactions with glutathione. Acta Pharmacol. et. Toxicol. 54: 273-277.

Ardóser, F., Wolffram, S. \& Scharrer, E. 1985. Active absorption of selenate by rat ileum. J. Nutr. 115: 1203-1208.

Bartholomew, R.J. \& Delaney, A.M. 1964. Proc. Austr. Assoc. Clin. Biochem. 1:64.

Behne, D. \& Hofer-Bosse, T. 1984. Effects of low selenium status on the distribution and retention of selenium in the rat. J. Nutr. 114:1289-1296.

- \& Wolters, W. 1979. Selenium content and glutathione peroxidase activity in the plasma and erythrocytes of non-pregnant and pregnant women. J. Clin. Chem. Clin. Biochem. 17:133.

- \& Wolters, W. 1983. Distribution of selenium and glutathione peroxidase in the rat. J. Nutr. 113:456461.

Beilstein, M.A., Butler, J.A. \& Whanger, P.D. 1984. Metabolism of ${ }^{75} \mathrm{Se}$-selenite by rhesus monkeys. J. Nutr. 114:1501-1509.

- \& Whanger, P.D. 1986a. Deposition of dietary organic and inorganic selenium in rat rat erythrocyte proteins. J. Nutr. 116:1701-1710.

— \& Whanger, P.D. 1986b. Chemical forms of selenium in rat tissues after administration of selenite or selenomethionine. J. Nutr. 116:1711

Binnerts, W.T., Rijken, J. \& Viets T.C. 1984. The selenium content in milk as an indicator of the selenium status of cows. Trace Elem. Anal. Chem. Med. Biol., Proc. Int. Workshop, 3rd, pp. 129-137. (Eds. Braetter, P and Schramel, P. De Gruyter), Berlin.

Bozkurt, A. \& Sмітн, J.C. 1981. The interaction between cadmium and selenium in the rat. In: Selenium in Biology and Medicine (Eds. Spallholz, J.E., Martin, J.L. and Ganther, H.E.), pp. 331-335, Avi Publishing Co., Westport, CT.

Brown, D.G., Burk, R.F., Seely,R.J. \& Kiker, K.W. 1972. Effect of dietary selenium on the gastrointestinal absorption of ${ }^{75} \mathrm{SeO}_{3}{ }^{2-}$ in the rat. Int. J. Vitam. Nutr. Res. 42:588.

BURK, R.F. 1973. Effect of dietary selenium level on ${ }^{75} \mathrm{Se}$ binding to rat plasma proteins. Proc. Soc. exp. Biol. Med. 143:719-722.

- 1974. In vivo ${ }^{75} \mathrm{Se}$ binding to human plasma proteins after administration of ${ }^{75} \mathrm{SeO}_{3}{ }^{2-}$. Biochim. Biophys. Acta 372:255-265.

- 1976. Selenium in man. In: Trace elements in human health and disease. Volume II. Essential and toxic elements. pp. 105-133. (Eds. Prasad, A.S. \& Oberleas, D.). Academic Press, New York.

- 1978. Selenium in nutrition. World Rev. Nutr. Diet. 30:88-106.

-, Brown, D.G., Seely, R.J. \& Scaief, C.C. 1972. Influence of dietary and injected selenium on wholebody retention, route of excretion, and tissue retention of ${ }^{75} \mathrm{SeO}_{3}{ }^{2-}$ in the rat. J. Nutr. 102:1049-1056.

- \& Gregory, P.E. 1982. Some characteristics of ${ }^{75} \mathrm{Se}-$ 
$\mathrm{P}$, a selenoprotein found in rat liver and plasma, and comparison of it with selenoglutathione peroxidase. Arch. Biochem. Biophys. 213:73-80.

—, Pearson, W.N., Wood, R.P. \& Viteri, F. 1967. Blood selenium levels and in vitro red blood cell uptake of ${ }^{75} \mathrm{Se}$ in Kwashiorkor. Am. J. Clin. Nutr. 20:723.

—, Seely, R.J. \& KIKer, K.W. 1973. Selenium: dietary threshold for urinary excretion in the rat. Proc. Soc. exp. Biol. Med. 142:214-216.

Butler, G.W. \& Peterson, P.J. 1967. Uptake and metabolism of inorganic forms of selenium-75 by Spirodela oligorrizha. Austr. J. Biol. Sci. 20:77-86.

Butler, J.A., Beilstein, M.A. \& Whanger, P.D. 1985. Incorporation of selenium from selenite and selenomethionine in rat tissues. Fed. Proc. 44:1510.

-, Whanger, P.D. Kaneps, A.J. \& Patton, N.M. 1990. Metabolism of selenite and selenomethionine in the rhesus monkey. J. Nutr. 120:751-759.

-, Whanger, P.D. \& Tripp, M.J. 1982. Blood selenium and glutathione peroxidase activity in pregnant women: Comparative assays in primates and other animals. Am. J. Clin. Nutr. 36:15-23.

Carlstróm, G. 1979. On the determination of glutathione peroxidase. The distribution of the enzyme between blood plasma and erythrocytes in different animals. 21st World Veterinary Congress, Moscow, 55.

Cary, E.E., Allaway, W.H. \& Miller, M. 1973. Utilization of different forms of dietary selenium. J. Anim. Sci. 36:285.

Cavalieri, R.R, Dickard, R., Searle, G.I. \& Scott, K.G. 1967. Uptake of selenium labeled with selenium75 by human leukocytes in vitro. Nature 215:10911092.

Chavez, E.R. 1979. Effect of dietary selenium on glutathione peroxidase activity in piglets. Can. J. Anim. Sci. 59:67-75.

Comвs, G.F., Jr. 1976. Differential effects of high dietary levels of vitamin A on the vitamin E - Selenium nutrition of young and adult chickens. J. Nutr. 106: 967-975.

— \& ComBs, S.B. 1984. The nutritional biochemistry of selenium. Annual Reviews of Nutrition 4:257-280.

- \& Pesti, G.M. 1976. Influence of ascorbic acid on selenium nutrition in the chick. J. Nutr. 106:958-966.

— \& Scotr, M.L. 1974. Antioxidant effects on selenium and vitamin E function in the chick. J. Nutr. 104: 1297-1303.

Conrad, H.R. \& Moxon, A.L. 1979. Transfer of dietary selenium to milk. J. Dairy Sci. 62:404-411.

Costa, N.D., Gleed, P.T., Sansom, B.F., Symonds, H.W. \& Allen, W.M. 1985. Monensin and narasin increase selenium and zinc absorption in steers. Trace Elements in Man Animals - TEMA 5, Proc. Int. Symp., 5th Meeting 1984, (Eds. Mills, C.F., Bremner, I. \& Chesters, J.K.), pp. 472-474. CAB: Farn- ham Royal Slough, UK.

Cummins, L.M. \& Martin, J.L. 1967. Are selenocystine and selenomethionine synthesized in vivo from sodium selenite in mammals? Biochemistry 3:31623168.

Deagen, J.T. \& Whanger, P.D. 1985. Influence of selenium status on selenite metabolism in the rat. Fed. Proc. 44:1510.

Debski, B., Picciano, M.F. \& Milner, J.A. 1987. Selenium content and distribution of human, cow and goat milk. J. Nutr. 117:1091-1097.

Dejneka, J., Nowosad, R. \& Simoni, J. 1979. Studies on radio-selenium ${ }^{75} \mathrm{Se}$ distribution in tissues and rumen content and on its excretion with bile, urine and faeces in sheep (Summary). Polskie Archiwum Veterynaryjne 21(2): 247-248.

Eberle, D.R., Clarke, R. \& Kaplowitz, N. 1981. Rapid oxidation in vitro of endogenous and exogenous glutathione in bile of rats. J. Biol. Chem. 256:21152117.

Ekholm, P., Ylinen, M. Eurola, M. Koivistoinen, P. \& VARO, P. 1991. Effects of general soil fertilization with sodium selenate in Finland on the selenium content of milk, cheese and eggs. Milchwissenchaft (in press).

Esaki, J., Karal, N., Nakamura, T., Tanaka, H. \& SODA, K. 1985. Mechanism of reactions catalyzed by selenocysteine $\beta$-lyase. Arch. Biochem. Biophys. 238:418-423.

-, Nakamura, T., TANaka, H. \& Soda, K. 1982. Selenocysteine lyase, a novel enzyme that specifically acts on selenocysteine. J. Biol. Chem. 257:43864391.

-, Nakamura, N., Tanaka, H., Suzuki, T., Morino, Y. \& SodA, K. 1981. Enzymatic synthesis of selenocysteine in rat liver. Biochemistry 20:44924496.

Ettala, E., Nenonen, E. \& Lampila, M. 1972. Nurmirehujen säilöntätappioista. Kehittyvă maatalous 7 : 16-28 (In Finnish).

Fisher, L.J., Hoogendoorn, C. \& Montemurro, J. 1980. The effect of added dietary selenium on the selenium content of milk, urine and feces. Can. J. Anim. Sci. 60:79-86.

Flohe, L., Gonzler, W.A. \& Schook, H.H. 1973. Glutathione peroxidase: A selenoenzyme. FEBS Lett. $32: 132-134$.

Foster, S.J. \& Ganther, H.E. 1984. Synthesis of ${ }^{75} \mathrm{Se}-$ trimethyl selenoniumiodide from ${ }^{75} \mathrm{Se}$-selenocystine. Anal. Biochem. 137:205.

-, Kraus, R.J. \& Ganther H.E. 1986a. Formation of dimethyl selenide and trimethylselenonium from selenobetaine in the rat. Arch. Biochem. Biophys. 247:12-19.

- Kraus, R.J. \& Ganther H.E. 1986b. The metabolism of selenomethionine, selenium-methylselenocysteine, their selenonium derivates, and trimethyl- 
selenonium in the rat. Arch. Biochem. Biophys. 247: $77-86$.

Fuss, C.N. \& Godwin, K.O. 1975. A comparison of the uptake of ${ }^{75} \mathrm{Se}$-selenite, ${ }^{75} \mathrm{Se}$-selenomethionine and ${ }^{35} \mathrm{~S}$-methionine by tissues of ewes and lambs. Aust. J. Biol. Sci. 28:239-249.

Ganther, H.E. 1968. Selenotrisulfides: Formation by the reaction of thiols with selenious acid. Biochemistry 7:2898.

- 1971. Reduction of the selenotrisulfide derivate of glutathione to a persulfide analog. Biochemistry 10 : 4089-4098.

- \& Baumann, C.A. 1962. Selenium metabolism. II Modifying effect of sulphate. J. Nutr. 77:408-414.

- \& Hsien, H.S. 1974. Mechanism for the conversion of selenite to selenides in mammalian tissues. In: Trace Element Metabolism in Animals -2 (eds. Hoekstra, W.G., Suttle, J.W., Ganther, H.E. \& Mertz, W.). Universtity Park Press, Baltimore.

-, Levander, O.A. \& Baumann, C.A. 1966. Dietary control of selenium volatilization in the rat. J. Nutr. 88:55.

Gasiewicz, T.A. \& Sмiтh, J.C. 1978. The metabolism of selenite by intact rat erythrocytes in vitro. Chem. Biol. Interactions 21:299-313.

Gissel-Nielsen, G. 1976. Selenium in soils and plants. Proceedings of the symposium on Selenium-Tellurium in the environment. Univ. Notre Dame, Indiana.

- 1982. Transport and metabolism of selenium in plants. In: Selenium, Glutathione Peroxidase and Vitamin E. 12th Linderström-Lang Conference, IUB symposium No. 110, Laugarvatn, Iceland.

- 1987. Fractionation of selenium in barley and ryegrass. J. Plant Nutr. 10:2147-2152.

Godwin, K.O., Handreck, K.A. \& Fuss, C.N. 1971. Identification of ${ }^{75} \mathrm{Se}$-selenomethionine in ewe milk protein following the intraruminal administration of $\mathrm{Na}_{2}{ }^{75} \mathrm{SeO}_{3}$ as a single oral dose. Austr. J. Biol. Sci. 24: $1251-1261$.

GoMeZ, B. \& TAPPEL, A.L. 1989. Selenoprotein P receptor from rat. Biochim. Biophys. Acta 979:20-26.

Grace, N.D. \& Watkinson, J.H. 1988. Se, Cu, Zn and Fe metabolism of the young lamb. Proc. N. Zealand Soc. Anim. Prod. 48:257-260.

Greger, J.L. \& Marcus, R.E. 1981. Effect of dietary protein, phosphorus and sulphur amono acids on selenium metabolism of adult males. Ann. Nutr. Metab. 25:97-108.

Gregus, Z. \& KlaAssen, C.D. 1986. Disposition of metals in rats: a comparative study of faecal urinary and biliary excretion and tissue distribution of eighteen metals. Toxicol. Appl. Pharmacol. 85:24-38.

Grovum, W.L. \& Phillips, G.D. 1973. Rate of passage of digesta in sheep. 5. Theoretical considerations based on a physical model and computer simulation. $\mathrm{Br}$. J. Nutr. 30:377-390.

— \& Williams, V.J. 1973. Rate of passage in sheep. 4.
Passage of marker through alimentary tract and biological relevances of rate-constants derived from changes in concentration of marker in faeces. Br. J. Nutr. 30:313-329.

Gúnzler, W.A., Kremers, H. \& Flohe, L. 1974. Zeitschrift für Klinische Chemie und Klinische Biochemie. 12:444-448.

Hafeman, D.G., Sunde, R.A. \& Hoekstra, W.G. 1974. Effect of dietary selenium on erythrocyte and liver glutathione peroxidase in rat. J. Nutr. 104:580-587.

HandRECK, K.A. \& Godwin, K.O. 1970. Distribution in the sheep of selenium derived form ${ }^{75} \mathrm{Se}$-labelled ruminal pellets. Aust. J. Agric. Res. 21:71-84.

Hansen, J.C. \& Kristensen, P. 1979. The Kinetics of ${ }^{75} \mathrm{Se}$-selenium in relation to dose and mode of administration to mice. J. Nutr. 109:1223-1233.

Hansson, E. \& Blau, M. 1963. Incorporation of ${ }^{75} \mathrm{Se}-$ selenomethionine into pancreatic juice proteins in vivo. Biochem. Biophys. Res. Communications 13: $71-74$.

- \& JACOBSEN, S. 1966. Uptake of ${ }^{75}$ Se-selenomethionine in the tissues of the mouse studied by whole-body autoradiography. Biochim. Biophys. Acta 7:66-76.

Harrison, J.H. \& Conrad, H.R. 1984a. Effect of selenium intake on selenium utilization by the nonlactating dairy cow. J. Dairy Sci. 67:219-223.

— \& ConRad, H.R. 1984b. Effect of dietary calcium on selenium absorption by the nonlactating dairy cow. J. Dairy Sci. 67: 1860-1864.

Hawkes, W.C., Lyons, D. \& TAPPel, A.L. 1982. Biochim. Biophys. Acta 699:183-191.

- \& TAPPEL, A.L. 1983. In vitro synthesis of glutathione peroxidase from selenite: translational incorporation of selenocysteine. Biochim. Biophys. Acta 739:225-234.

-, Wilhelmsen, E.C. \& TAPpel, A.L. 1983. The biochemical forms and tissue and subcellular distribution of selenium in rat (Abstr.). Fed. Proc. 42:928.

HE, Y. ZHU, L. 1988. The effect of dietary vitamin E on the metabolism of selenium in rats raised with Keshan disease diets. Yingyang Xuebao 10:16-21.

Henry, R.J., Cannon, D.C. \& Winkelman, J.W. 1974. Clinical chemistry principles and technics. pp. 413416. New York.

Herrman, J.L. \& McConnell, K.P. 1974. The binding of selenium to serum albumin. In: Trace Element Metabolism in Animals -2 (Eds. Hoekstra, W.G., Suttle, J.W., Ganther, H.E. \& Mertz, W.). University Park Press, Baltimore.

Hidiroglou, M., Heaney, D.P. \& Jenkins, K.J. 1968. Metabolism of inorganic selenium in rumen bacteria. Can. J. Physiol. Pharmacol. 64:229-232.

— \& Jenkins, K.J. 1973. Absorption of 75-selenomethionine from the rumen of sheep. Can. J. Anim. Sci. 54:325-330.

— \& JenKInS, K.J. 1974. Fate of ${ }^{75}$ Se-selenomethionine in the gastrointestinal tract of sheep. In: Trace Ele- 
ment Metabolism in Animals -2 (Eds. Hoekstra, W.G., Suttle, J.W., Ganther, H.E. \& Mertz, W.). University Park Press, Baltimore.

—, Jenkins, K.J. \& KNIPfel, J.E. 1974. Metabolism of selenomethionine in the rumen. Can. J. Anim. Sci. 53:527-536.

HıLL, C.H. 1979. Studies on the ameliorating effect of ascorbic acid on mineral toxicities in the chick. J. Nutr. 109:84-90.

Hirooka, T. \& Gal.ambos, J.T. 1966. Selenium metabolism. III. Serum proteins, lipoproteins and liver injury. Biochim. Biophys. Acta 130:321-328.

Hopkins, L.L., Pope, A.L. \& Baumann, C.A. 1966. Distribution of microgram quantities of selenium in the tissues of the rat, and effects of previous selenium intake. J. Nutr. 88:61-65.

Hsieh, H.S. \& Ganther, H.E. 1975. Acid-Volatile selenium formation catalyzed by glutathione reductase. Biochemistry 14:1632.

- \& Ganther, H.E. 1977. Biosynthesis of dimethyl selenide from sodium selenite in rat liver and kidney cell-free systems. Biochem. Biophys. Acta 497:205.

Huber, R.E., \& Criddle, R.S. 1967. Comparison of the chemical properties of selenocysteine and selenocystine with their sulfur analogs. Arch. Biochem. Biophys. 122:164-173.

Hudman, J.F. \& GlenN, A.R. 1984. Selenite uptake and incorporation by Selenomonas ruminantum. Arch. Microbiol. 140:252-256.

Huida, L., VãĂTÃınen, H. \& Lampila, M. 1986. Comparison of dry matter contents in grass silages as determined by oven drying and gas-chromatographic water analysis. Ann. Agric. Fenn. 25:215-230.

Humaloja, T. \& MykKănen H.M. 1986. Intestinal absorption of ${ }^{75} \mathrm{Se}$-labeled sodium selenite and selenomethionine in chick: Effect of time, segment, selenium concentration and method of measurement. J. Nutr. 116:142-148.

HYvĭ̃añnen A. \& NiKKILĀ, E. 1962. Yksinkertainen veren glukoosin măăritysmenetelmă. Duodecim 78:305307.

Imbach, A. \& Sternberg, J. 1967. Metabolic studies with selenited compounds. J. Appl. Radiat. Isotop. 18: 545-556.

Jacobsen, S.O. Oksanen, H.E. \& Hansson, E. 1965. Excretion of selenium in the milk of sheep. Acta Vet. Scand. 6:299-312.

JenKINS, K.J. 1968. Evidence for the absence of selenocystine and selenomethionine in the serum proteins of chicks administered selenite. Can. J. Biochem. 46:1417-1425.

- \& Hidiroglou, M. 1967. The incorporation of ${ }^{75} \mathrm{Se}-$ selenite into dystrophogenic pasture grass. The chemical nature of the seleno compounds formed and their availability to young ovine. Can. J. Biochem. 45: 1027-1040.

— \& Hidiroglou, M. 1971. Transmission of selenium as selenite and as selenomethionine from ewe to lamb via milk using selenium-75. Can. J. Anim. Sci. 51: 389-403.

— \& Hidiroglou, M. 1972. Comparative metabolism of ${ }^{75} \mathrm{Se}$-selenite, ${ }^{75} \mathrm{Se}$-selenate and ${ }^{75} \mathrm{Se}$-selenomethionine in bovine erythrocytes. Can J. Physiol. Pharmacol. 50:927.

- \& Hidiroglou, M. 1988. Binding of selenium-75 to blood in liver cytosolic proteins in the preruminant calf. J. Dairy Sci. 71:442-451.

- \& Hidiroglou, M. \& RYAN, J.F. 1969. Intravascular transport of selenium by chick serum proteins. Can. J. Physiol. Pharmacol. 47:459-467.

JoNEs, G.B. \& GodwIN, K.O. 1963. Studies on the nutritional role of selenium. 1. The distribution of radioactive selenium in mice. Austr. J. Agric. Res. 14: $716-722$.

Keenan, T.W. \& Dylewske, D.P. 1985. Aspects of intracellular transit of serum and lipid phases of milk. J. Dairy Sci. 68:1025-1040.

KhIRWAR, S.S. \& ARORA, S.P. 1977. Incorporation of ${ }^{75} \mathrm{Se}$-selenomethionine in milk proteins of goats. Milchwissenschaft 32:283-284.

KICE, J.L. 1981. The mechanism of the reaction of thiols with selenite and other Se (IV) species. In: Selenium in Biology and Medicine (Eds. Spallholz, J.E., Martin, J.L. and Ganther, H.E.), pp. 17-32, Avi Publishing Co., Westport, CT.

KIKER, K.W. \& BURK R.F. 1974. Production of urinary selenium metabolites in the rat following ${ }^{75} \mathrm{SeO}_{3}$ administration. Am. J. Physiol. 227:643-646.

Koenig, K.M., Buckley, W.T. \& Shelford, J.A. 1989. Use of seleniumstable isotopes to determine the effect of supplemental copper on true absorption of dietary selenium in dairy cows. Can. J. Anim. Sci. 69:297.

Kolв, E. 1967. Lehrbuch der physiologie der haustiere. VEB Gustaf Fisher Verlag, Jena. p. 375.

Koller, L.D., Whitbeck, G.A. \& South, P.J. 1984. Transplacental transfer and colostrum concentration of selenium in beef cattle. Am. J. Vet. Res. 45: $2507-2510$.

Kristensen, P. \& Hansen, J.C. 1980. Urinary and fecal excretion of selenium $\left(\mathrm{Na}_{2}{ }^{75} \mathrm{SeO}_{3}\right)$ and mercury $\left({ }^{203} \mathrm{HgCl}_{2}\right)$ administered separately and simultaneously to mice. Toxicology 16:39-47.

Kumpulainen, J. Raittila, Am., Lehto, J. \& Koivistoinen, P. 1983. Electrothermal atomic absorption spectrometric determination of selenium in foods and diets. J. Assoc. Off. Anal. Chem. 66:1129-1135.

Ladenstein, R., Epp, O., Bartels, K. Jones, A. Huber, R. \& Wendel, A. 1979. Structure analysis and molecular model of the selenoenzyme glutathione peroxidase at 2.8 Å resolution. J. Mol. Biol. 134:199.

Langlands, J.P., Bowles, J.E., Donald, G.E. \& Smith, A.J. 1986. Selenium excretion in sheep. Austr. J. Agric. Res. 37:201-209. 
Lazarov, E. \& Ivanov, N. 1970. Resorption of sulfurcontaining amino acids in the rumen of ruminants. Zhivotnovadni Nauki. 7:43-48.

Lee, M., Dong, A. \& YAno, J. 1969. Metabolism of ${ }^{75}$ Se-selenite by human whole blood in vitro. Can. J. Biochem. 47:791.

Levander, O.A. \& Baumann, C.A. 1966. Selenium metabolism. V. Studies on the distribution of selenium in rats given arsenic. Toxicol. Appl. Pharmacol. 9: 106.

Lloyd, L.E., McDonald, B.E. \& Crampton, E.W. 1978. Fundamentals of nutrition. p. 30. W.H. Freeman and Company. San Francisco.

Lopez, P.L., Preston, R.L. \& Pfander, W.H. 1968. Whole-body retention, tissue distribution and excretion of selenium-75 after oral and intravenous administration in lambs fed varying selenium intakes. J. Nutr. 97:123-132.

Martin, J.L. 1973. Selenium assimilation in animals. In: Organic Selenium Compounds: Their chemistry and biology (Eds. Klayman, D.L. Günther, W.H.H.) pp. 663-691. Wiley, New York.

Mas, A., Jiang, J. \& Sarkar, B. 1988. Selenite metabolism in rat and human blood. Biol. Trace Elem. Res. 15:97-100.

Mason, A.C. \& WeAver, C.M. 1986. Metabolism in rats of selenium from intrinsically and extrinsically labeled isolated soy protein. J. Nutr. 116:1883-1888.

Mathias, M.M., Hogue, D.E. \& Loosli, J.E. 1967. The biological value of selenium in bovine milk for the rat and chick. J. Nutr. 93:14-20.

Maus, R.W., Martz, F.A., Belyea, R.L. \& Weiss, M.F. 1980. Relationship of dietary selenium in plasma and milk from dairy cows. J. Dairy Sci. 63:532-537.

McConnel, K.P. \& CHo, G.J. 1965. Transmucosal movement of selenium. Am.J.Physiol. 208:593-600.

— \& Сно, G.J. 1967. Active transport of L-selenomethionine in the intestine. Am.J.Physiol. 213:150156.

- \& Hoffman, J.L. 1972. Methionine - selenomethionine parallels in rat liver polypeptide chain synthesis. FEBs Letters 24:60-62.

McMurray, C.H. \& Davidson, W.B. 1979. In vitro metabolism of selenium in sheep blood; factors controlling the distribution of selenium and the labelling of plasma proteins. Biochim. Biophys. Acta 583: 332343.

Meng, X., Yu, w., Zeng, S., Zhou, B. \& Kang, B. 1987. Influence of manganese on selenium metabolism in rats. Yingyang Xuebao 9:97-104.

MillaR, K.R. 1972. Distribution of ${ }^{75}$ Se in liver, kidney and blood proteins of rats after intravenous injection of sodium selenite. N. Z. J. Agric. Res. 15:547-563.

-, Gardiner, M.A. \& Sheppard, A.D. 1973. A comparison of the metabolism of intravenously injected sodium selenite, sodium selenate and selenomethionine in rats. N. Z. J. Agric. Res. 16:115-127.
Morris, V.C. \& Levander, O.A. 1986. Urinary trimethylselononium ion (TMSe) as an index of selenium (Se) exposure in rats (Abstr.) Fed. Proc. 45:474.

MotSEnBoCKer, M.A. \& TAPPEL, A.L. 1982a. Selenocysteine-containing proteins from rat and monkey plasma. Biochem. Biophys. Acta 704:253-260.

- \& TAPPEL, A.L. 1982b. Selenium and selenoproteins in the rat kidney. Biochem. Biophys. Acta 704:160165.

— \& TAPPEL, A.L. 1982c. A selenocysteine-containing seleniumtransport protein in rat plasma. Biochem. Biophys. Acta 719:147-153.

— \& TAPPEL, A.L. 1984. Effect of dietary selenium on plasma selenoprotein $\mathrm{P}$, selenoprotein $\mathrm{P} 1$ and glutathione peroxidase in the rat . J. Nutr. 114:279285.

MykkÄnen, H.M. \& Humaloja, T. 1984. Effect of lead on the intestinal absorption of sodium selenite and selenomethionine $\left({ }^{75} \mathrm{Se}\right)$ in chicks. Biol. Trace Elem. Res. 6:11.

- \& Mutanen, M.L. 1983. Effect of ascorbic acid on the intestinal absorption of ${ }^{75}$ Se-selenite in chicks. Nutr. Rep. Intern. 28:67-73.

- \& Mutanen, M.L. 1986. Intestinal interactions of ascorbic acid with different selenium compounds in chicks. Nutr. Rep. Int. 33:575-583.

Nahapetian, A.T., Janghorbani, M. \& Young, V.R. 1983. Urinary trimethylselenonium excretion by the rat: Effect of level and source of selenium-75. J. Nutr. 113:401-411.

Neathery, M.W., Miller, W.J., Gentry, R.P., Crowe, C.T., Alfaro, E., Fielding, A.S., Puhg, D.G. \& BLACKMON, D.M. 1987. Influence of high dietary lead on selenium metabolism in dairy calves. J. Dairy Sci. 70:645-652.

Nigam, S.N. \& McConnell, W.B. 1976. Metabolism of $\mathrm{Na}_{2}{ }^{75} \mathrm{SeO}_{4}$ in Astragalus bisulcatus Lima Bean, and Wheat: a comparative study. J. Exp. Botany 27:565571.

Obermeyer, B.D., Palmer, I.S., Olson, O.E. \& HalverSON, A.W. 1971. Toxicity of trimethylselenonium chloride in the rat with and without arsenite. Toxicol. Appl. Pharmacol. 20:135-146.

Оh, S.H., Ganther, H.E. \& Hoekstra, W.G. 1974. Selenium as a component of glutathione peroxidase isolated from ovine erythrocytes. Biochemistry 13: 1825-1829.

Olson, O.E., Novacek, E.J., Whitehead, E.I. \& PalMER,I.S. 1970. Investigations on selenium in wheat. Phytochemistry 9:1181-1188.

Ostadalova, I., Babicky, A. \& Kopoldova, J. 1988. Selenium metabolism in rats after administration of toxic doses of selenite. Physiol. Bohemoslov. 37:159 164.

Palmer, I.S., Fischer, D.D., Halverson, A.W. \& OLSON, O.E. 1969. Identification of a major selenium excretory product in the rat urine. Biochim. Biophys. 
Acta 177:336-342.

-, Gunsalus, R.P., Halverson, A.W. \& Olson, O.E. 1970. Trimethyl-selenonium ion as a general excretory product from selenium metabolism in the rat. Biochim. Biophys. Acta 208:260-266.

Parsons, M.J., Ku, P.K., Ullrey, D.E., Stowe, H.D., Whetter, P.A. \& Miller, E.R. 1985. Effects of riboflavin supplementation and selenium source on selenium metabolism in the young pig. J. Anim. Sci. $60: 451-461$.

Paulson, G.C., Baumann, C.A. \& Pope, A.L. 1966. Fate of physiological dose of selenate in the lactating ewe: Effect of sulfate. J. Anim. Sci. 25:1054-1058.

-, Baumann, C.A. \& Pope, A.L. 1968. Metabolism of ${ }^{75} \mathrm{Se}$-selenite, ${ }^{75} \mathrm{Se}$-selenate, ${ }^{75} \mathrm{Se}$-selenomethionine and 35 -S-sulfate by rumen microorganisms in vitro. J. Anim. Sci. 27:497-504.

Pehrson, B., Knutsson, M. \& Gyllenswärd, M. 1989. Glutathione peroxidase activity in heifers fed diets supplemented with organic and inorganic selenium compounds. Swedish J. agric. Res. 19:53-56.

Perry, T.W., Peterson, R.C. \& Beeson, W.M. 1977. Selenium in milk from feeding small supplements. J. Dairy Sci. 60:1698-1700.

Pesti, G.M. \& Coмвs, G.F. 1976. Studies on enteric absorption of selenium in the chick using localized coccidial infections. Poultry Sci. 55:2265-2274.

Peter, D.W., Hunter, R.A., Whanger, P.D. \& BusCALL, D.J. 1985. Feed intake as a factor influencing selenium metabolism in young sheep. Trace Elements in Man Animals - TEMA 5, Proc. Int. Symp., 5th Meeting 1984, (Eds. Mills, C.F., Bremner, I. \& Chesters, J.K.), pp. 487-490. CAB: Farnham Royal Slough, UK.

Peterson, P.J. \& Butler, G.W. 1962. The uptake and assimilation of selenite by higher plants. Austr. J. Biol. Sci. 15:126.

- \& Spedding, D.J. 1963. The excretion by sheep of ${ }^{75}$ selenium incorporated into red clover (Trifolium pratense L.): The chemical nature of the excreted selenium and its uptake by three plant species. N.Z. J. Agric. Res. 6:13-23.

Piironen, V., Varo, P., Syvãoja, E-L., Salminen, K. \& KoIvistoinen, P. 1985. High-performance liquid chromatographic determination of tocopherols and tocotrienols and its application to diets and plasma of Finnish men. 1. Analytical method. Intern. J. Vit. Nutr. Res. 53:35-40.

Pope, A.L., Molr, R.J., Somers, M. Underwood, E.J. \& White, C.I. 1979. The effect of sulphur on ${ }^{75} \mathrm{Se}$ absorption and retention in sheep. J. Nutr. 109: 1448-1455.

Porter, E.K., Karle, J.E. \& Schrift, A. 1979. Uptake of selenium-75 by human lymphosytes in vitro. $\mathrm{J}$. Nutr. 109:1901-1908.

Preston, R.L., Schaeffer, J.E. \& Curran, P.F. 1974. Structure-affinity relationship substrates for the neu- tral amino acid transport system in rabbit ileum. J. Gen. Physiol. 64:443-467.

Raghib, M.H., Chan, W.Y. \& Rennert, O.M. 1986. Comparative studies of selenium-75 (selenite and selenomethionine absorption from various milk diets in suckling rats. J. Nutr. 116:1456-63.

Raнiм, A.G.A. 1985. The effects of dietary L-ascorbic acid on the absorption and utilization of sodium [ $\left.{ }^{75} \mathrm{Se}\right]$ selenite $\left(\mathrm{Na}_{2}{ }^{75} \mathrm{SeO}^{3}\right)$ of silver-treated rats. Comp. Biochem. Pysiol. C: Comp. Pharmacol. Toxicol. 81C:131-132.

-, Arthur, J.R. Mills, C.F. 1986. Effects of dietary copper, cadmium, iron, molybdenum and manganese on selenium utilization by the rat. J. Nutr. 116: 403-411.

Robinson, M.F. Rea, H.M., Friend, G.M., Stewart, R.D., Snow, P.G. \& Thomson, C.D. 1978. On supplementing the selenium of New Zealanders. 2. Prolonged metabolic experiments with supplements of selenomethionine, selenite and fish. Br. J. Nutr. 39:589-600.

Robinson, J.R., Robinson, M.F., Levander, O.A. \& Thомson, C.D. 1985. Urinary excretion of selenium by New Zealand and North American human subjects on differing intakes. Am. J. Clin. Nutr. 41:10231031.

Rodvien, R., Gillum, A. \& Wantraub, L.R. 1974. Decreased glutathione peroxidase activity secondary to severe iron deficiency: a possible mechanism responsible for the shortened life span of the iron deficient red cell. Blood 43:281-290.

Rosenfeld, I. 1962. Biosynthesis of seleno-compounds from inorganic selenium by sheep. Proc. Soc. Exp. Biol. Med. 111:670.

Rotruck, J.T., Pope, A.L., Ganther, H.E., Swanson, A.B. Hafeman, D. \& Hoekstra, W.G. 1973. Selenium: Biochemical role as a component of glutathione peroxidase. Science 179:588-590.

SAARI, E. \& PAASO, A. 1980. Mineral element composition of Finnish foods. II Analyticl methods. Acta Agr. Scand. Suppl. 22:15-25.

Salbe, A.D. \& Levander, O.A. 1990. Effect of various dietary factors on the deposition of selenium in the hair and nails of rats. J. Nutr. 120:200-206.

SAlo, M-L., Tuori, M. \& KiISKInen, T. 1982. Rehutaulukot ja ruokintanormit. 70 p. Helsinki. (In Finnish)

Salonen, J.T., Alfthan, G., Pikkarainen, J., Huttunen, J.K. \& PUSKA, P. 1982. Association between cardiovascular death and myocardial infarction and serum selenium in a matched-pair longitudinal study. Lancet 2:175-179.

SAndholm, M. 1973a. The initial fate of a trace amount of intravenously administered selenite. Acta Pharmacol. Toxicol. 33:1-5.

- 1973b. The metabolism of selenite in cow blood in vitro. Acta Pharmacol. Toxicol. 33:6-16.

- 1974. Selenium carrier proteins in mouse plasma. Acta 
Pharmacol. Toxicol. 35:424-428.

- 1975. Function of erythrocytes in attaching seleniteSe onto specific plasma proteins. Acta Pharmacol. Toxicol. 36:321-327.

- \& SIPPONEN, P. 1973. Formation of unstable seleniteglutathione complex in vitro. Arch. Biochem. Biophys. 155:120.

SANKARI, S. 1985. Plasma glutathione peroxidase and tissue selenium response to selenium supplementation in swine. Acta Vet. Scand. Suppl. 81.

Shariff, M.A. \& Krishnamurti, C.R. 1987. Kinetics of whole body selenium in nonpregnent ewes. Can. J. Anim. Sci. 67:1207.

- \& Krishnamurti, C.R. 1989. Kinetics of whole-body selenium (Se) metabolism in pregnant sheep. Can. J. Anim. Sci. 69:296.

Shippley, R.A. \& Clark, R.E. 1972. Tracer methods for in vivo kinetics. Academic Press. London. $239 \mathrm{p}$.

SHrIFT, A. 1969. Aspects of selenium metabolism in higher plants. Ann. Rev. Plant Physiol. 20:475-494.

- 1973. Metabolism of selenium by plants and microorganisms. In: Organic Selenium Compounds: Their chemistry and biology. (Eds. Klayman, D.L. \& Günther, W.H.H.) pp. 760-814. Wiley New York.

Sies, H., Кoch, O.T., Martino, E. \& Boveris, A. 1979. Increased biliary glutathione disulfide release in chronically ethanoltreated rats. FEBS Lett. 103:287-290.

Sippola, J. 1979. Selenium content of soils and timothy (Phleum pratense L.) in Finland. Ann. Agric. Fenn. 18:182-187.

Snedecor, G.W. \& Cochran, W.G. 1980. Statistical methods. 7th editon. The Iowa State University Press. Ames, Iowa.

Soda, K., Esakı, N., Nakamura, T. \& TAnaka, H. 1981. Enzymatic synthesis of selenocysteine in rat liver. In: Selenium in Biology and Medicine (Eds. Spallholz, J.E., Martin, J.L. and Ganther, H.E.), pp. 427-431, Avi Publishing Co., Westport, CT.

Sokal, R.R. \& Rohlf, F.J. 1981. Biometry. The Principles and Practice of Statistics in Biological Research. 2nd ed. pp. 208-231. W.H. Freeman and Co, San Francisco.

Stevens, J.B., Olson, W.G., Kraemer, R. \& ArchamBEAU, J. 1985. Serum selenium concentrations and glutathione peroxidase activities in cattle grazing forages of various selenium concentrations. Am. J. Vet. Res. 46:1556-1560.

Sunde, R.A., Ganther, H.E. \& Hoekstra, W.G. 1978. A comparison of ovine liver and erythrocyte glutathione peroxidase. Fed. Proc. 37:757 (abstr.).

Sunde, R.A. \& Hoekstra, W.G. 1980. Structure, synthesis and function of glutathione peroxidase. Nutrition Reviews 38: 265-273.

- \& Hoekstra, W.G. 1981. Use of the isolated, perfused rat liver to study the synthesis of glutathione peroxidase. In: Selenium in Biology and Medicine (Eds. Spallholz, J.E., Martin, J.L. and Ganther,
H.E.), pp. 454-459, Avi Publishing Co., Westport, CT.

Sword, J.T., Ataja, A., Pope, A.L. \& Hoekstra, W.G. 1984. Effect of calcium phosphates and zinc in saltmineral mixtures on ad libitum salt-mix intake and on zinc and selenium status of sheep. J. Anim. Sci. 59:1594-1600.

Symonds, H.W., Mather, D.L. \& VAGG, M.J. 1981 a. The excretion of selenium in bile and urine of steers: the influence of form and amount of Se salt. Br. J. Nutr. 46:487-493.

-, Sansom, B.F., Mather, D.L. \& VAGG, M.J. 1981 b. Selenium metabolism in the dairy cow: the influence of the liver and the effect of the form of Se salt. Br. J. Nutr. 45:117-125.

TAlke, H. \& Schubert, G.E. 1965. Enzymatische Harnstoffbestimmung in Blut und Serum in optischen Test nach Warbung. Klin. Wschr. 43:174-175.

Thompson, K.G., McMurray, C.H. \& Blanchflower, W.J. 1976. The levels of selenium and glutathione peroxidase activity in blood of sheep, cows and pigs. Res. Vet. Sci. 20:229-231.

Thomson, C.D. \& Stewart, R.D.H. 1973. Metabolic studies of ${ }^{75} \mathrm{Se}$ - selenomethionine and ${ }^{75} \mathrm{Se}$-selenite in the rat. Br. J. Nutr. 30:139-147.

-, Robinson, B.A., Stewart, R.D.H. \& Robinson, M.F. 1975. Metabolic studies of ${ }^{75} \mathrm{Se}$-selenocystine and ${ }^{75} \mathrm{Se}$-selenomethionine in the rat. Br. J. Nutr. 34:501-509.

Tilley, J. \& Terry, R. 1963. A two-stage technique for in vitro digestion of forage crops. $\mathrm{J}$. Br. Grassl. Soc. 18:104-111.

Tsay, D.T., Halverson, A.W. \& Palmer, I.S. 1970. Inactivity of dietary trimethylselenonium chloride against the necrogenic syndrome of the rat. Nutr. Rep. Int. 2:203-207.

TUori, M. \& Poutiainen, E. 1982. Feeding a fixed amount of concentrate and ad lib. silage to dairy cows during early lactation. 33rd Annual Meeting of the EAAP. Leningrad, Soviet Union.

Turner, J.C., Osborn, P.J. \& McVEAGH, S.M. 1990. Studies on selenate and selenite absorption by sheep ileum using an everted sac method and an isolated, vascularly perfused system. Comp. Biochem. and Physiol. A, Comp. Physiol. 95:297-301.

Tykkyläinen, P., Nuurtamo, M. \& Aspila, P. 1985. Seleenin siirtyminen maitoon ja maitovalmisteisiin. Karjantuote 1985 (6) pp. 28-31. (In Finnish).

ULREY, D.E. 1981. Selenium in the soil-plant food chain. In: Selenium in biology and medicine. (Eds. Spallholz, J.E., Martin, J.L. \& Ganther, H.E.) pp. 176-197, Avi. Publishing Company, Westport, CT.

UNDERWOOD, E.J. 1981. The mineral nutrition of livestock. 2nd ed. C.A.B. Page Bros. Ltd., Norwich.

van KAMPEN, E.J. \& ZiJlstra, W.G. 1961. Standardization of hemoglobinometry. II The hemoglobincyanide method. Clin. Chim. Acta 6:538-544. 
van Ryssen, J.B., Deagen, J.T., Beilstein, M.A. \& Whanger, P.D. 1989. Comparative metabolism of organic and inorganic selenium by sheep. J. Agric. Food. Chem. 37:1358-1363.

-, Miller, W.J., R.P. Gentry, \& Neathery, M.W. 1987. Effect of added dietary cobalt on metabolism and distribution of radioactive selenium and stable minerals. J. Dairy Sci. 70:639-644.

VARo, P. \& KoIVISTOINEn, P. 1981. Int. J. Vit. Nutr. Res. 51:79-84.

VENKov, T. 1969. Research on the resorption capability of the alimentary tract of lambs treated with selenium dioxide. Vet. Med. Nauk. 6:27-30.

VoKal-Borek, H. 1980. Selenium. Institute of Theoretical Physics, University of Stockholm, Report 79-16.

Waite, R., Conrad, H.R. \& Moxon, A.L. 1975. Metabolism of selenium-75 in dairy cows. J. Dairy Sci. 58: 749-750.

Whanger, P.D., Pedersen, N.D., Hatfield, J. \& Weswig, P.H. 1976. Absorption of selenite and selenomethionine from ligated digestive tract segments in rats. Proc. Soc. Exp. Biol. Med. 153:295-297.

-, Weswig, P.H., Oldfield, J.E., Cheeke, P.R. \& Muth, O.H. 1967. Metabolism of 75-selenite and 75-selenomethionine by rumen microorganisms. Fed. Proc. 27:418.

—, Weswig, P.H., Schmitz, J.A. \& Oldfield, J.E. 1977. Effects of selenium and vitamin $\mathrm{E}$ on blood selenium levels, tissue glutathione peroxidase activities and white muscle disease in sheep fed purified or hay diets. J. Nutr. 107:1298-1307.

White, C.L. \& Somers, M. 1977. Sulphur-selenium studies in sheep. The effects of varying dietary sulphate and selenomethionine on sulphur, nitrogen and selenium metabolism in sheep. Austr. J. Biol. Sci. $30: 47-56$.

Wolffram, S., Anliker, E. \& Scharrer, E. 1986. Uptake of selenate and selenite by isolated brush border membrane vesicles from pig, sheep and rat. Biol. Trace Elem. Res. 10:293-306.

-, Ardúser, F. \& Scharrer, E. 1985. In vivo intestinal absorption of selenate and seienite by rats. J. Nutr.
$115: 454-459$.

-, Berger, B., Grenacher, B. \& Scharrer, E. 1989. Transport of selenoamino acids and their sulfur analogues across the intestinal brush border membrane of pigs. J. Nutr. 119:706-712.

-, Grenacher, B. \& Scharrer, E. 1988. Transport of selenate and sulfate across the intestinal brush-border membrane of pig jejunum by two common mechanisms. Q. J. Exp. Physiol. 73:103-111.

-, Stingelin, Y. \& Scharrer, E. 1987. Inhibition of sulfate and selenate transport in sheep jejunum by oxalate and other dicarboxylate anions. J. Vet. Med. Ser. A. 34:679-683.

Wright, P.L. \& Bell, M.C. 1966. Comparative metabolism of selenium and tellurium in sheep and swine. Am. J. Physiol. 211:6-10.

Wormli, R., Wolffram, S., Stingelin, Y. \& Scharrer, E. 1989. Stimulation of mucosal uptake of selenium from selenite by L-cysteine in sheep small intestine. Biol. Trace Elem. Res. 20:75-85.

Xia, Y., Oldfield, J.E., Beilstein, M.A. \& Whanger, P.D. 1985. Metabolism of orally administered ${ }^{75} \mathrm{Se}-$ selenite by the pig. Nutr. Res. 5:543-553.

YLÄANTA, T. 1984a. Effect of selenium fertilization and foliar spraying at different growth stages on the selenium content of spring wheat and barley. Ann. Agric. Fenn. 23:85-95.

- 1984b. Effect of selenite and selenate fertilization and foliar spraying on selenium content of timothy grass. Ann. Agric. Fenn. 23:96-108.

Yoshida, M., Yasumoto, K., Iwami, K. \& Tashiro, H. 1981. Distribution of selenium in bovine milk and selenium deficiency in rats fed casein-based diets monitored by lipid peroxidase level and glutathione peroxidase activity. Agric. Biol. Chem. 45:1681-1688.

Zanetti, M.A., Nunes, F.M. \& Pivatto, C.C. 1987. Selenium balance in sheep receiving added dietary selenium. Rev. Soc. Bras. Zootec. 16:331-336.

Zeisel, S.H., Ellis, A.L. Sun, X.F., Pomfret, E.A., TING, B.T. \& JANGhorbni, M. 1987. Dose-response relations in urinary excretion of trimethylselenonium in the rat. J. Nutr. 117:1609-1614. 


\section{SELOSTUS}

\section{Seleeniaineenvaihdunta maitoa tuottavalla vuohella ja lehmällä}

\author{
Pentti Aspila \\ Helsingin yliopisto \\ kotieläintieteen laitos \\ 00710 Helsinki
}

Tutkimuksen tarkoituksena oli selvittăă epăorgaanisen ja orgaanisen seleenin aineenvaihduntaa maitoa tuottavilla vuohilla ja lypsylehmillă useilla seleenitasoilla.

Tutkimus koostuu kahdesta vuohilla ja yhdestả lehmillă suoritetusta kokeesta. Vuohille annettiin kerta-annoksena joko viikoa ennen niittoa $\mathrm{Na}_{2}{ }^{75} \mathrm{SeO}_{3}$ :llă ruiskutettua ruohoa, pötsinsisăisesti (I.R.) $\mathrm{Na}_{2}{ }^{75} \mathrm{SeO}_{3}$ :ă tai suonensisäisesti (I.V.) $\mathrm{Na}_{2}{ }^{75} \mathrm{SeO}_{3}$ tai ${ }^{75} \mathrm{Se}$-selenometioniinia. Seurantajaksojen pituus oli $15-28 \mathrm{~d}$. Käytetyt seleenitasot olivat $0.05,0.22$, ja $0.34 \mathrm{mg} \mathrm{Se} / \mathrm{kg}$ ka. Tulokset esitetään ${ }^{75} \mathrm{Se}$ imeytymisestă, erittymisestă maidossa, virtsassa ja sonnassa sekä ${ }^{75}$ Se-aktiivisuudesta plasmassa, erytrosyyteissä ja karvassa. Lehmillă suoritettu koe kesti $539 \mathrm{~d}$ ja siină 48 lehmaalle annettiin joko $\mathrm{Na}_{2} \mathrm{SeO}_{3}$ :ă tai săilörehua, jolle oli viikkoa ennen korjuuta ruiskutettu $\mathrm{Na}_{2} \mathrm{SeO}_{3}$ :ă. Dieetin seleenipitoisuus vaihteli vălillä $0.03 \mathrm{ja} 1.8 \mathrm{mg} \mathrm{Se} / \mathrm{kg}$ ka. Tulokset esitetaăn maidon, plasman ja erytrosyyttien seleenipitoisuudesta sekä plasman ja erytrosyyttien GSHPx -aktiivisuudesta.
${ }^{75}$ Se todellinen imeytyminen oli $63 \%$ ja $65 \%$ sekä erittyminen maidossa $4 \%$ ja $7 \%$ vuohilla, joille annettiin $\mathrm{Na}_{2}{ }^{75} \mathrm{SeO}_{3}$ I.R. tai ${ }^{75} \mathrm{Se}$ :llă leimattua ruohoa. Dieetin seleenipitoisuudella ei ollut vaikutusta ${ }^{75} \mathrm{Se}: \mathrm{n}$ imeytymiseen tai erittymiseen maidossa. Kun ${ }^{75} \mathrm{Se}$ annettiin I.V., $3.6 \%$ seleniitistă ja $33 \%$ selenometioniinista erittyi maidossa. $\mathrm{Na}_{2}{ }^{75} \mathrm{SeO}_{3}$ erittyi pääasiassa virtsassa.

Lehmillä, joilla $\mathrm{Na}_{2} \mathrm{SeO}_{3}$ oli seleenin lähteenă, maidon seleenipitoisuus oli $0.011,0.011,0.016$ ja 0.020 , kun dietin seleenipitoisuus oli $0.11,0.17,0.42 \mathrm{ja} 0.68 \mathrm{mg} \mathrm{Se} / \mathrm{kg}$ ka. Selenoidun săilörehun ollessa seleenin lähteenă maidon seleenipitoisuus oli $0.023,0.020,0.029 \mathrm{ja} 0.040 \mathrm{mg} / \mathrm{l}$ dieetin seleenipitoisuuden ollessa $0.09,0.20,0.45$ ja 1.20 $\mathrm{mg} / \mathrm{kg}$ ka. Selenoitu säilörehu nosti maidon seleenipitoisuutta voimakkaammin $(\mathrm{p}<0.001)$ kuin $\mathrm{Na}_{2} \mathrm{SeO}_{3}$. Kun seleenitäydennyksen jälkeen eläinten seleenin saantia rajoitettiin aleni maidon seleenipitoisuus nopeammin lehmillä, jotka olivat saaneet $\mathrm{Na}_{2} \mathrm{SeO}_{3}$ :ä kuin lehmillä, jotka olivat saaneet selenoitua säilörehua. 
Appendix 1 .

Rate constants, retention time and half-life in experiments 1 and 2.

Experiment 1.

Oral dose of ${ }^{75} \mathrm{Se}$-labeled grass (Phase I).

\begin{tabular}{|c|c|c|c|c|c|c|}
\hline & \multicolumn{2}{|c|}{ Milk } & \multicolumn{2}{|c|}{ Urine } & \multicolumn{2}{|c|}{ Faeces } \\
\hline & $\mathrm{D}^{\prime}$ & $\mathrm{S}^{2}$ & D & $\mathrm{S}$ & D & $\mathrm{S}$ \\
\hline$k_{1}$ & 1.623 & 1.919 & N.D. & N.D. & 1.484 & 2.406 \\
\hline $\mathrm{k}_{2}$ & 0.778 & 0.849 & 0.664 & 0.389 & 0.961 & 1.040 \\
\hline$k_{3}$ & 0.061 & 0.096 & 0.062 & 0.065 & 0.081 & 0.039 \\
\hline TMRT & 18.7 & 12.6 & 18.3 & 22.5 & 52.2 & 28.1 \\
\hline$T_{1 / 2}$ & 11.5 & 7.4 & 11.6 & 13.7 & 34.7 & 18.2 \\
\hline
\end{tabular}

1 Goats fed diet containing $0.05 \mathrm{mg} \mathrm{Se} / \mathrm{kg} \mathrm{DM}(\mathrm{n}=2)$

${ }^{2}$ Goats fed diet containing $0.22 \mathrm{mg} \mathrm{Se} / \mathrm{kg} \mathrm{DM}(\mathrm{n}=2)$

N.D., not determined

Intraruminal dose of ${ }^{75} \mathrm{Se}$-labeled sodium selenite (Phase II).

\begin{tabular}{|c|c|c|c|c|c|c|}
\hline & \multicolumn{2}{|c|}{ Milk } & \multicolumn{2}{|c|}{ Urine } & \multicolumn{2}{|c|}{ Faeces } \\
\hline & D & $\mathrm{S}$ & D & $\mathrm{S}$ & D & $\mathrm{S}$ \\
\hline$k_{1}$ & N.D. & 2.707 & 3.742 & 2.127 & 2.637 & 2.169 \\
\hline $\mathrm{k}_{2}$ & 1.462 & 1.380 & 0.898 & 1.105 & 0.909 & 1.026 \\
\hline$k_{3}$ & 0.027 & 0.048 & 0.019 & 0.068 & 0.139 & 0.102 \\
\hline TMRT & 38.4 & 23.7 & 53.0 & 17.5 & 9.9 & 12.0 \\
\hline $\mathbf{T}_{y_{2}}$ & 26.1 & 15.5 & 35.7 & 11.0 & 5.3 & 6.8 \\
\hline
\end{tabular}

Intravenous dose of ${ }^{75} \mathrm{Se}$-labeled selenomethionine (Phase III)

\begin{tabular}{|c|c|c|c|c|c|c|}
\hline & \multicolumn{2}{|c|}{ Milk } & \multicolumn{2}{|c|}{ Urine } & \multicolumn{2}{|c|}{ Faeces } \\
\hline & D & $\mathrm{S}$ & D & $\mathrm{S}$ & D & $\mathrm{S}$ \\
\hline$k_{1}$ & 1.546 & 4.959 & 11.238 & 9.952 & 4.183 & 5.171 \\
\hline $\mathrm{k}_{2}$ & 0.627 & 1.204 & 0.858 & 1.716 & - & - \\
\hline $\mathrm{k}_{3}$ & 0.090 & 0.100 & 0.032 & 0.043 & 0.042 & 0.074 \\
\hline TMRT & 13.7 & 13.0 & 35.8 & 31.4 & 25.5 & 16.3 \\
\hline $\mathbf{T}_{1 / 2}$ & 7.7 & 8.2 & 23.8 & 20.4 & 12.8 & 10.1 \\
\hline
\end{tabular}


Appendix 1 (continued).

Experiment 2.

Oral dose of ${ }^{75}$ Se-labeled grass (OR) or intraruminal dose of ${ }^{75}$ Se-labeled sodium selenite (IO) (Phase I).

\begin{tabular}{|c|c|c|c|c|c|c|}
\hline & \multicolumn{2}{|c|}{ Milk } & \multicolumn{2}{|c|}{ Urine } & \multicolumn{2}{|c|}{ Faeces } \\
\hline & $\mathrm{IO}^{1}$ & $\mathrm{OR}^{2}$ & IO & OR & IO & OR \\
\hline$k_{1}$ & 2.654 & 5.348 & 2.997 & 2.099 & 1.386 & 1.327 \\
\hline$k_{2}$ & 1.518 & 1.779 & 2.655 & 1.027 & 0.891 & 0.685 \\
\hline $\mathrm{k}_{3}$ & 0.237 & 0.364 & 0.112 & 0.094 & 0.078 & 0.082 \\
\hline $\mathrm{k}_{4}$ & 0.054 & 0.049 & - & - & - & - \\
\hline TMRT & 38.4 & 23.7 & 53.0 & 17.5 & 9.9 & 12.0 \\
\hline$T_{y_{k}}$ & 26.1 & 15.5 & 35.7 & 11.0 & 5.3 & 6.8 \\
\hline
\end{tabular}

1 Goats fed sodium selenite $0.38 \mathrm{mg} \mathrm{Se} / \mathrm{kg}$ DM $(\mathrm{n}=1)$

${ }^{2}$ Goats fed selenited barley $0.34 \mathrm{mg} \mathrm{Se} / \mathrm{kg} \mathrm{DM}(\mathrm{n}=2)$

Intravenous dose of ${ }^{75} \mathrm{Se}$-labeled selenomethionine (OR) or ${ }^{75} \mathrm{Se}$-labeled sodium selenite (IO) (Phase II).

\begin{tabular}{|c|c|c|c|c|c|c|}
\hline & \multicolumn{2}{|c|}{ Milk } & \multicolumn{2}{|c|}{ Urine } & \multicolumn{2}{|c|}{ Faeces } \\
\hline & $\mathrm{IO}^{1}$ & $\mathrm{OR}^{2}$ & IO & OR & IO & OR \\
\hline$k_{1}$ & 5.060 & 9.902 & - & - & 3.460 & 2.894 \\
\hline $\mathrm{k}_{2}$ & 1.009 & 1.837 & 1.700 & 2.252 & 1.240 & 1.976 \\
\hline$k_{3}$ & 0.274 & 0.324 & 0.073 & 0.068 & 0.082 & 0.090 \\
\hline$k_{4}$ & 0.068 & 0.059 & - & - & - & - \\
\hline TMRT & 19.6 & 20.7 & 13.7 & 15.2 & 13.5 & 12.3 \\
\hline$T_{1 / 2}$ & 10.2 & 11.8 & 9.7 & 10.4 & 8.4 & 7.8 \\
\hline
\end{tabular}

${ }^{1}$ Goats fed sodium selenite $0.38 \mathrm{mg} \mathrm{Se} / \mathrm{kg}$ DM $(\mathrm{n}=2)$

${ }^{2}$ Goats fed selenited barley $0.34 \mathrm{mg} \mathrm{Se} / \mathrm{kg}$ DM $(\mathrm{n}=2)$ 
Appendix 2.

Mineral composition of feeds in experiment 3.

\begin{tabular}{|c|c|c|c|c|c|c|c|c|c|c|c|c|}
\hline \multirow{2}{*}{\multicolumn{2}{|c|}{$\begin{array}{l}\text { Feed } \\
\text { Phase }\end{array}$}} & \multicolumn{4}{|c|}{ Control silage } & \multicolumn{3}{|c|}{ Selenited silage } & \multirow{2}{*}{$\begin{array}{c}\text { Grass } \\
\mathrm{V}\end{array}$} & \multicolumn{3}{|c|}{ Hay } \\
\hline & & II & III & IV & VI & II & III & IV & & II-III & IV & $\mathrm{V}-\mathrm{V}$ \\
\hline $\mathrm{Ca}$, & $\mathrm{g} / \mathrm{kg} \mathrm{DM}$ & 9.7 & 8.0 & 5.7 & 8.2 & 7.9 & 7.5 & 4.7 & 11.4 & 7.7 & 3.1 & 2.4 \\
\hline $\mathrm{P}$, & $\mathrm{g} / \mathrm{kg} \mathrm{DM}$ & 2.5 & 3.1 & 3.0 & 4.0 & 2.9 & 3.1 & 3.5 & 4.2 & 3.1 & 2.3 & 2.5 \\
\hline $\mathrm{Mg}$, & $\mathrm{g} / \mathrm{kg} \mathrm{DM}$ & 2.7 & 2.4 & 1.7 & 2.2 & 2.1 & 2.3 & 1.5 & 3.0 & 1.6 & 1.0 & 1.0 \\
\hline $\mathrm{S}$, & $\mathrm{g} / \mathrm{kg} \mathrm{DM}$ & 1.9 & 1.9 & 1.5 & 2.2 & 2.3 & 2.1 & 2.3 & 2.6 & 1.5 & 1.1 & 1.1 \\
\hline $\mathrm{Fe}$, & $\mathrm{mg} / \mathrm{kg} \mathrm{DM}$ & 518 & 1023 & 330 & 549 & 180 & 490 & 260 & 1865 & 218 & 98 & 124 \\
\hline $\mathrm{Zn}$, & $\mathrm{mg} / \mathrm{kg} \mathrm{DM}$ & 30 & 32 & 30 & 57 & 29 & 25 & 38 & 68 & 27 & 21 & 26 \\
\hline $\mathrm{Se}$, & $\mathrm{mg} / \mathrm{kg} \mathrm{DM}$ & 0.03 & 0.03 & 0.02 & 0.02 & 0.20 & 0.55 & 1.69 & 0.03 & 0.02 & 0.01 & 0.02 \\
\hline
\end{tabular}

Mineral composition of feeds (continued)

\begin{tabular}{|c|c|c|c|c|c|c|c|c|c|c|c|}
\hline \multirow{2}{*}{$\begin{array}{l}\text { Feed } \\
\text { Phase }\end{array}$} & & \multicolumn{3}{|c|}{ Concentrate } & \multicolumn{2}{|c|}{$\begin{array}{c}\text { Protein } \\
\text { concentrate }\end{array}$} & \multirow{2}{*}{$\begin{array}{c}\begin{array}{c}\text { Selenited } \\
\text { barley }\end{array} \\
\mathrm{V}\end{array}$} & \multicolumn{3}{|c|}{ Mineral mixture } & \multirow{2}{*}{$\frac{\begin{array}{c}\text { Selenite } \\
\text { preparatio }\end{array}}{\text { II-V }}$} \\
\hline & & II-III & IV & $\mathrm{V}-\mathrm{VI}$ & II-IV & $\mathrm{V}-\mathrm{VI}$ & & II-III & IV & $\mathrm{V}-\mathrm{VI}$ & \\
\hline $\mathrm{Ca}$, & $\mathrm{g} / \mathrm{kg} \mathrm{DM}$ & 6.5 & 6.5 & 7.5 & 23.1 & 20.9 & 0.4 & 193 & 193 & 206 & 370 \\
\hline $\mathrm{P}$ & $\mathrm{g} / \mathrm{kg} \mathrm{DM}$ & 5.8 & 5.7 & 6.8 & 9.8 & 10.5 & 4.6 & 64 & 64 & 82 & $<0.1$ \\
\hline $\mathrm{Mg}$ & $\mathrm{g} / \mathrm{kg} \mathrm{DM}$ & 1.9 & 1.9 & 2.3 & 3.0 & 3.2 & 1.4 & 20.3 & 20.3 & 30.9 & 7.4 \\
\hline $\mathrm{S}$, & $\mathrm{g} / \mathrm{kg} \mathrm{DM}$ & 1.3 & 1.2 & 1.6 & 5.3 & 6.0 & 1.5 & 8.0 & 8.0 & 2.2 & $<0.5$ \\
\hline $\mathrm{Fe}$, & $\mathrm{mg} / \mathrm{kg} \mathrm{DM}$ & 320 & 330 & 320 & 840 & 690 & 74 & 6390 & 6390 & 5870 & 2800 \\
\hline $\mathrm{Zn}$ & $\mathrm{mg} / \mathrm{kg} \mathrm{DM}$ & 112 & 111 & 112 & 710 & 730 & 40 & 2840 & 2840 & 2470 & 16 \\
\hline Se, & $\mathrm{mg} / \mathrm{kg} \mathrm{DM}$ & 0.04 & 0.04 & 0.02 & 0.73 & 0.26 & 1.39 & 0.30 & 0.28 & 0.26 & 116 \\
\hline
\end{tabular}


Appendix 3.

Dietary mineral content in experiment 3 .

\begin{tabular}{|c|c|c|c|c|c|c|c|c|c|}
\hline \multirow{2}{*}{\multicolumn{2}{|c|}{ Group }} & \multicolumn{4}{|c|}{ Period I } & \multicolumn{4}{|c|}{ Period II } \\
\hline & & 1 & 2 & 3 & 4 & 1 & 2 & 3 & 4 \\
\hline $\mathrm{Ca}$, & $\mathrm{g} / \mathrm{kg} \mathrm{DM}$ & 6.6 & 6.9 & 6.7 & 6.7 & 10.7 & 11.0 & 9.3 & 9.7 \\
\hline & $\mathrm{g} / \mathrm{kg} \mathrm{DM}$ & 4.2 & 4.4 & 4.2 & 4.3 & 3.7 & 3.9 & 4.2 & 4.1 \\
\hline $\mathrm{Mg}$ & $\mathrm{g} / \mathrm{kg} \mathrm{DM}$ & 2.2 & 2.2 & 2.2 & 2.2 & 2.7 & 2.7 & 2.2 & 2.2 \\
\hline & $\mathrm{g} / \mathrm{kg} \mathrm{DM}$ & 1.8 & 1.9 & 1.8 & 1.8 & 1.8 & 1.8 & 2.1 & 2.1 \\
\hline $\mathrm{Fe}$, & $\mathrm{mg} / \mathrm{kg} \mathrm{DM}$ & 220 & 230 & 220 & 220 & 510 & 500 & 260 & 260 \\
\hline $\mathrm{Zn}$, & $\mathrm{mg} / \mathrm{kg} \mathrm{DM}$ & 72 & 88 & 72 & 75 & 77 & 88 & 83 & 76 \\
\hline Se, & $\mathrm{mg} / \mathrm{kg} \mathrm{DM}$ & 0.20 & 0.31 & 0.21 & 0.21 & 0.07 & 0.17 & 0.20 & 0.29 \\
\hline
\end{tabular}

Dietary mineral content (continued)

\begin{tabular}{|c|c|c|c|c|c|c|c|c|c|c|}
\hline \multirow{2}{*}{\multicolumn{2}{|c|}{ Group }} & \multicolumn{4}{|c|}{ Period III } & \multicolumn{5}{|c|}{ Period IV } \\
\hline & & & 1 & 2 & 3 & 4 & 1 & 4 & 2 & 3 \\
\hline $\mathrm{Ca}$, & $\mathrm{g} / \mathrm{kg} \mathrm{DM}$ & 9.8 & 10.8 & 9.4 & 10.2 & 8.0 & 9.6 & & 7.2 & 9.1 \\
\hline & $\mathrm{g} / \mathrm{kg} \mathrm{DM}$ & 4.5 & 4.5 & 4.5 & 4.4 & 4.3 & 4.3 & & 4.6 & 4.6 \\
\hline $\mathrm{Mg}$ & $\mathrm{g} / \mathrm{kg} \mathrm{DM}$ & 2.5 & 2.5 & 2.4 & 2.4 & 1.8 & 1.8 & & 1.7 & 1.7 \\
\hline & $\mathrm{g} / \mathrm{kg} \mathrm{DM}$ & 1.8 & 1.8 & 1.9 & 1.9 & 1.5 & 1.4 & & 2.0 & 2.0 \\
\hline $\mathrm{Fe}$, & $\mathrm{mg} / \mathrm{kg} \mathrm{DM}$ & 840 & 860 & 520 & 540 & 400 & 400 & & 350 & 370 \\
\hline $\mathrm{Zn}$, & $\mathrm{mg} / \mathrm{kg} \mathrm{DM}$ & 95 & 97 & 94 & 86 & 93 & 93 & & 94 & 95 \\
\hline Se, & $\mathrm{mg} / \mathrm{kg} \mathrm{DM}$ & 0.08 & 0.42 & 0.45 & 0.78 & 0.06 & 0.68 & & 1.20 & 1.81 \\
\hline
\end{tabular}

Dietary mineral content (continued)

\begin{tabular}{|c|c|c|c|c|c|c|c|c|c|}
\hline \multirow{2}{*}{\multicolumn{2}{|c|}{ Group }} & \multicolumn{4}{|c|}{ Period V } & \multicolumn{4}{|c|}{ Period VI } \\
\hline & & 1 & 2 & 3 & 4 & 1 & 2 & 3 & 4 \\
\hline $\mathrm{Ca}$, & $\mathrm{g} / \mathrm{kg} \mathrm{DM}$ & 12.1 & 11.9 & 11.0 & 11.2 & 8.8 & 8.9 & 8.8 & 8.9 \\
\hline & $\mathrm{g} / \mathrm{kg} \mathrm{DM}$ & 5.7 & 5.8 & 5.6 & 5.6 & 5.0 & 5.0 & 5.1 & 5.0 \\
\hline $\mathrm{Mg}$ & $\mathrm{g} / \mathrm{kg} \mathrm{DM}$ & 3.1 & 2.9 & 2.8 & 2.8 & 2.3 & 2.3 & 2.3 & 2.3 \\
\hline & $\mathrm{g} / \mathrm{kg} \mathrm{DM}$ & 2.2 & 2.2 & 2.1 & 2.1 & 1.9 & 2.0 & 1.9 & 1.9 \\
\hline $\mathrm{Fe}$, & $\mathrm{mg} / \mathrm{kg} \mathrm{DM}$ & 560 & 550 & 540 & 550 & 1190 & 1050 & 1020 & 1080 \\
\hline $\mathrm{Zn}$, & $\mathrm{mg} / \mathrm{kg} \mathrm{DM}$ & 116 & 121 & 108 & 106 & 94 & 100 & 102 & 94 \\
\hline Se, & $\mathrm{mg} / \mathrm{kg} \mathrm{DM}$ & 0.03 & 0.11 & 0.09 & 0.17 & 0.04 & 0.04 & 0.04 & 0.04 \\
\hline
\end{tabular}

